\title{
Three Essays on Indonesian Political \\ Economy: Elite Capture, Corruption, and Female Policy Makers
}

\section{Dissertation}

in order to acquire the doctoral degree from the Faculty of Economic Sciences at the Georg-August-Universität Göttingen

Submitted by

Rivayani Darmawan

Born in Jakarta, Indonesia

Göttingen, 2014 


\section{$\underline{\text { Thesis Committee }}$}

First academic advisor

Second academic advisor

Member of the examination board

Date of oral examination
: Prof. Stephan Klasen, Ph.D.

: Prof. Dr. Menno P. Pradhan

: J-Prof. Dr. Sebastian Vollmer

: 12.12 .2014 
For my parents, Duhnur and Djohan 


\section{Acknowledgement}

I first thank Allah SWT, who has guided me and granted me the strength through the process of finishing this thesis. I owe my sincere gratitude to my advisor, Stephan Klasen, for his extraordinary support, intelligent guidance, and for giving me the opportunity to be part of the academic community of University of Göttingen. I also would like to thank Menno Pradhan and Sebastian Vollmer for serving on my thesis committee. I am indebted to Menno, who has handed me the seed of research topics back then in Jakarta and still continue to re-orient my ideas with his constructive comments. I also appreciate the support from Sebastian during my defense that I couldn’t think of a better third examiner. I further thank Remco Oostendorp and Simon Lange for helpful scientific advices, as well as Prof. Ari Kuncoro, Prof. Joachim von Braun, Holger Seebens, and ZEF family for their support and encouragement of my journey in pursuing my study. I gratefully acknowledged financial support from the German Academic Exchange Service (DAAD) and the Indonesian government, as well as the Collaborative Research Centre 990. Without their assistance, writing this thesis would have been impossible.

I am grateful to have good friends, Nicole Grunewald and Marion Krämer, who were always there when I did need some advice. Also Marica Lo Bue, Jana Kuhnt, Anna Minasyan, Malte Reimers, Ramona Rischke, Syamsul Pasaribu, Iqbal Irfany, and all those who are part of the Development Economics Research Group for the great time I had during my doctoral studies. Beyond the landscape of Göttingen, I thank the friendship from Martha Awo, Liu Dan, Eva Gutierrez, and Khrisna Vadlamannati who have sincerely supported me in many ways.

This thesis would not exist without the exceptional support of my family throughout my life. To my beloved mother, thank you for the love and your constant prayer. Although I have been far away for too long, I indeed always carry you in my heart. For my uncle Karel, thank you for always believe in me even in times when I hardly believe in myself. For my other half, Raymond, thank you for your unlimited love and unconditional support during my hard times. Finally, for my father, I wish I had a millisecond to share this happiness with you. I love you. 


\section{Contents}

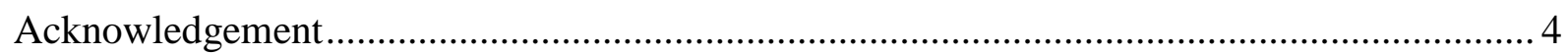

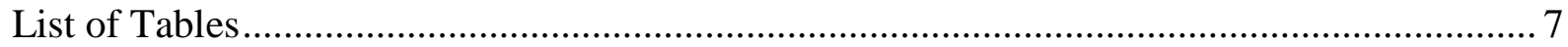

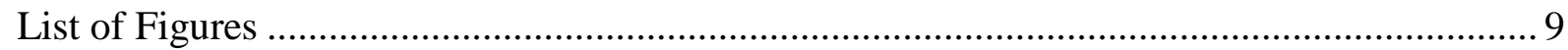

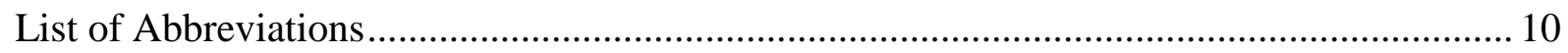

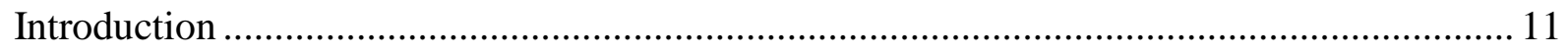

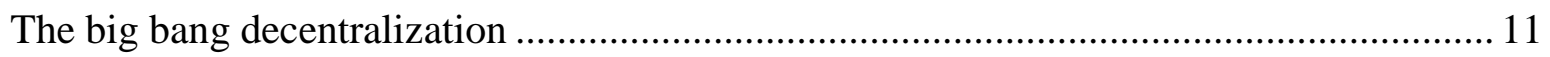

Involving communities to improve service delivery ................................................. 12

Fighting corruption in decentralized Indonesia.......................................................... 14

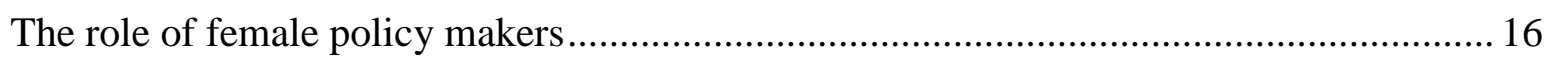

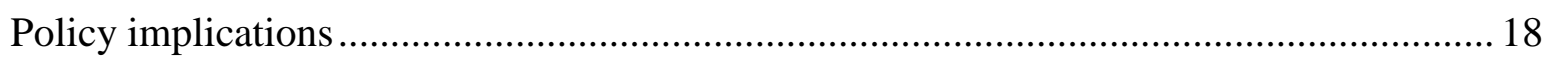

1 Elite capture in urban community-driven development: Evidence from Indonesia......... 20

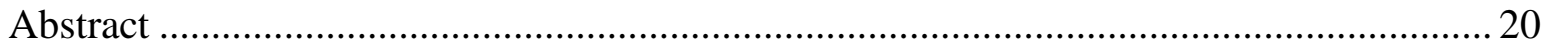

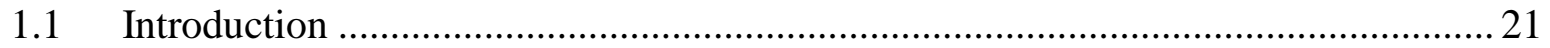

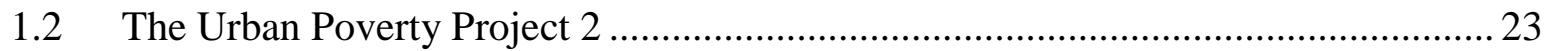

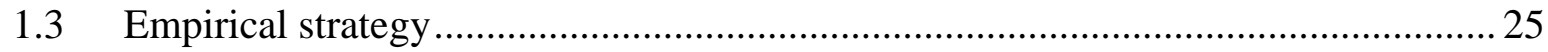

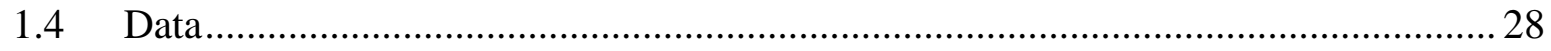

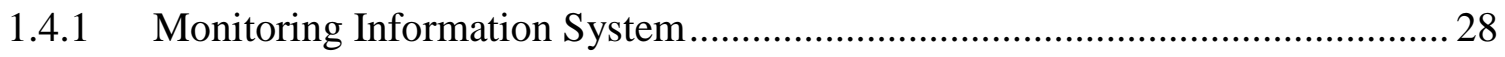

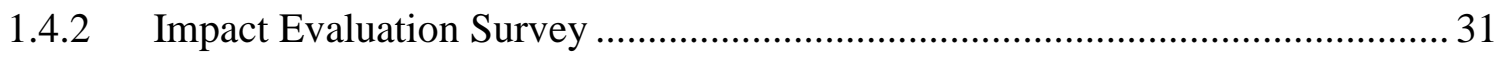

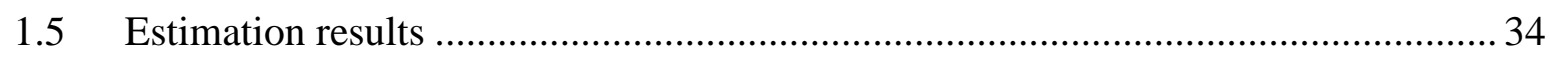

1.5.1 The composition of BKM members and project selection............................... 37

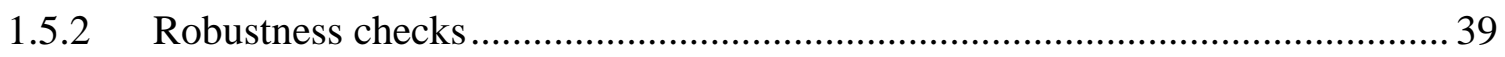

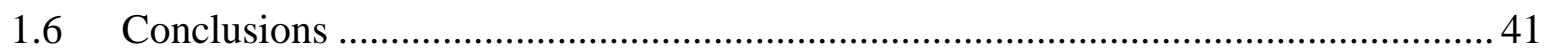

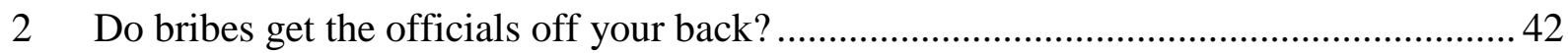

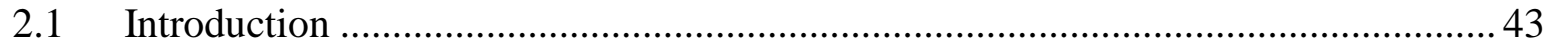

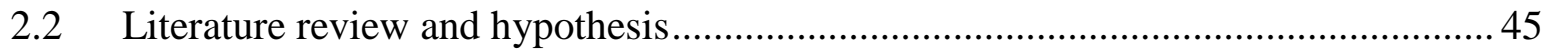




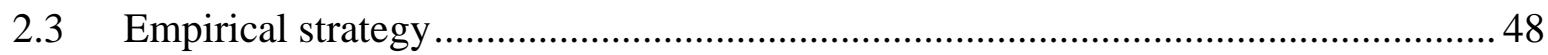

2.3.1 Competitive bribery with asymmetric information ....................................... 50

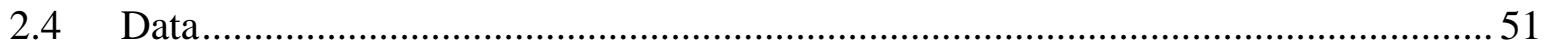

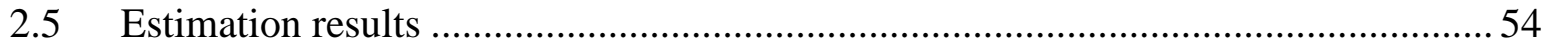

2.5.1 Competitive bribery with asymmetric information ....................................... 59

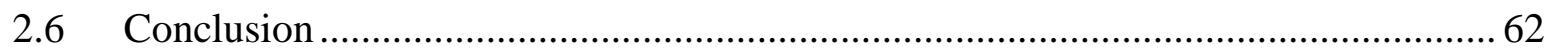

3 Women in power: Do women politicians stand up for their female voters? .................... 63

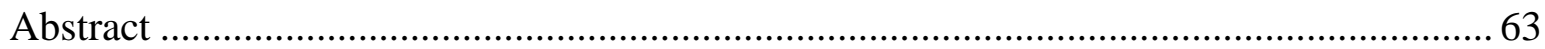

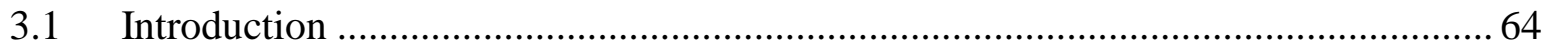

3.2 The selection of representatives and anti-poverty programs in UPP2 2.................... 67

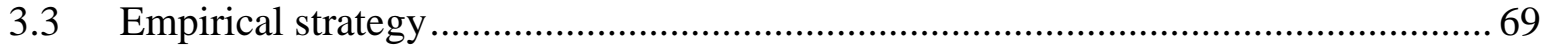

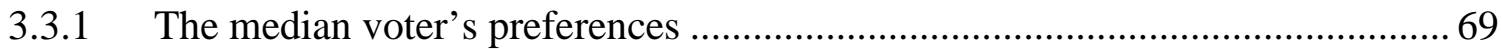

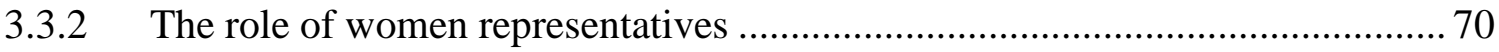

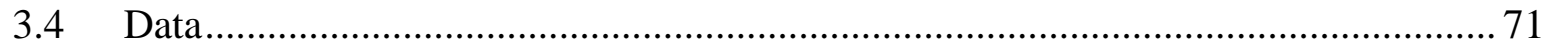

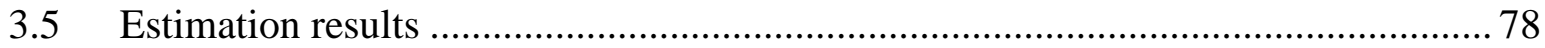

3.5.1 Median voter preference and female representation in BKM .......................... 78

3.5.2 Female representation and the gender gap in voter preferences ....................... 79

3.5.3 Female representation and the gender gap in preferences of BKM members.... 83

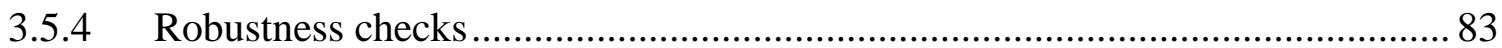

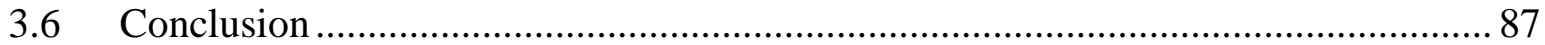

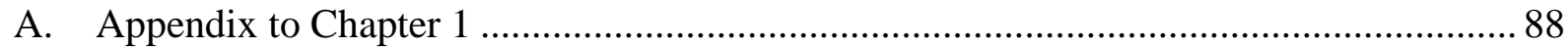

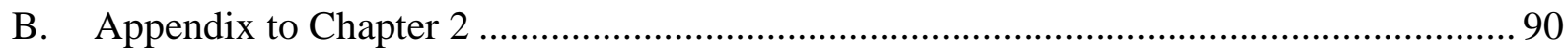

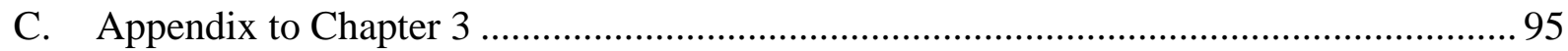

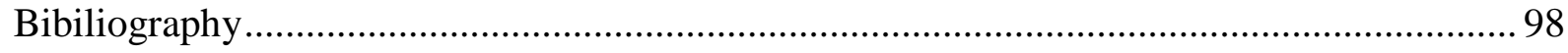




\section{List of Tables}

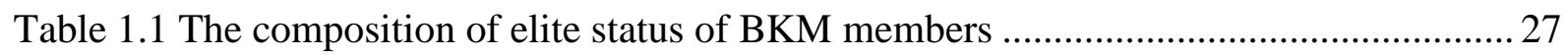

Table 1.2 Classification of UPP2 projects based on MIS data............................................... 29

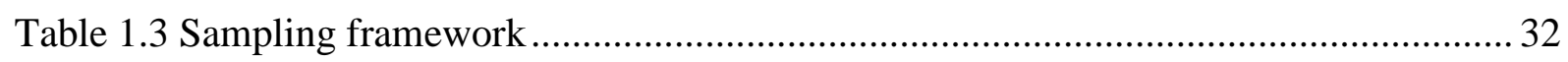

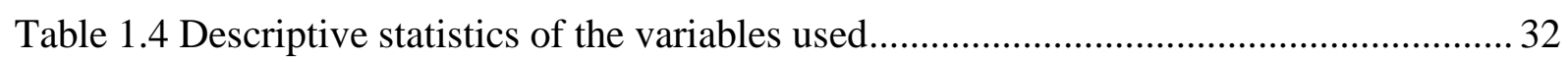

Table 1.5 Comparison between BKM members and the general population........................... 33

Table 1.6 Determinants of receiving private projects as the proportion of the total non-

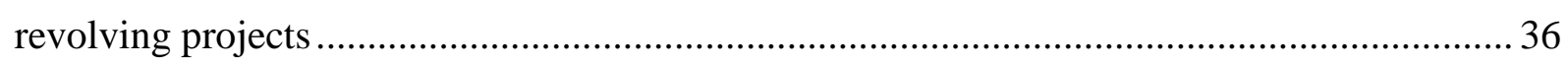

Table 1.7 Logistic regressions: determinants of community organization membership.......... 37

Table 1.8 Summary characteristics by BKM type .............................................................. 38

Table 1.9 Robustness check using alternative dependent variable ........................................ 40

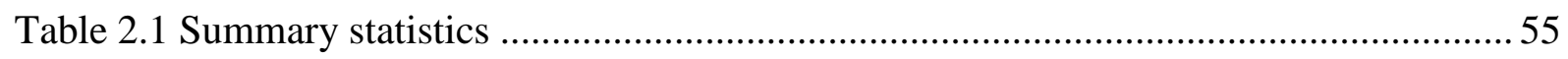

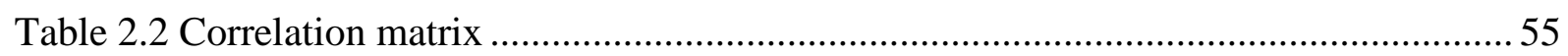

Table 2.3 Panel random effects: Bribe payments and time spent with officials ..................... 56

Table 2.4 2SLS regressions: Bribe payments and time spent with officials ........................... 57

Table 2.5 Non-linear relationship between the amount of bribes paid and the time spent with

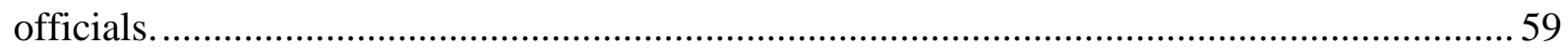

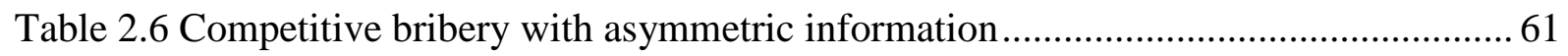

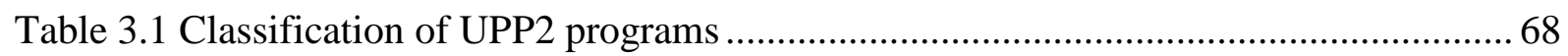

Table 3.2 Average UPP2 projects received by communities, by program type...................... 72

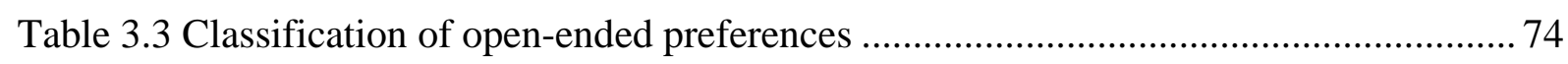

Table 3.4 Issues raised by women and men, voters and BKM members................................. 76

Table 3.5 Descriptive statistics for general population and BKM members, by gender.......... 77

Table 3.6 The role of median voter preference and female representatives in UPP2 budget allocation

Table 3.7 The role of female representatives and voter's gender gap in preferences in UPP2 budget allocation

Table 3.8 The role of BKM members' gender gap in preferences in UPP2 budget allocation 84 Table 3.9 Robustness check using alternative dependent variables, the role of the median voter and female representatives. 85

Table 3.10 Robustness check using alternative dependent variables, the role of voters' gender gap in preferences 86 
Table A1. Distribution of UPP2 projects, 2004-2007

Table A2. The construction of elite index using principal component analysis .....

Table B1. Different estimation methods: The relationships between bribes and the time spent with officials.

Table B2. Bribe payments and time spent with officials, 2SLS full results 92

Table B3. The relationship between bribes and time spent with officials, by sector .93

Table B4. Non-linear relationship between bribes and the time spent with officials, 2SLS full results .94

Table C1. Descriptive statistics. . 96

Table C2. Women's participation in UPP2 96

Table C3. Robustness check, using alternative dependent variables, the role of BKM members' preferences 97 


\section{List of Figures}

Figure 1.1 Distribution of UPP2 projects by project's cost and quantity, 2004-2007 ............ 30

Figure 2.1 Sample distribution by location, size, and manufacturing sector ........................... 51

Figure 2.2 Frequency of bribe payments in the last six month .............................................. 53

Figure 2.3 Average official visits in the last six months ...................................................... 53

Figure 2.4 Bribe payments and time spent with officials in two periods ............................... 53

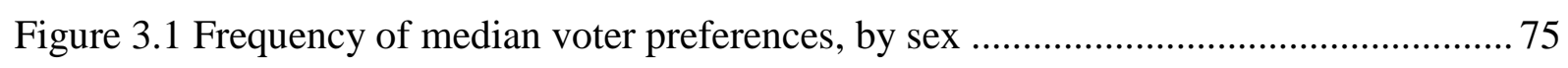

Figure 3.2 Effect of the share of females in BKM on public sanitation budget (95\% CIs).... 80 


\section{List of Abbreviations}

\begin{tabular}{|c|c|}
\hline AIC & Akaike Information Criterion \\
\hline $\mathrm{BIC}$ & Bayesian Information Criterion \\
\hline BKM & Community Board Trustee \\
\hline BPS & National Statistical Office Indonesia \\
\hline CDD & Community-driven Development \\
\hline CDP & Community Development Plan \\
\hline FE & Fixed Effects \\
\hline FGD & Focus Group Discussion \\
\hline GE & General Entropy \\
\hline GLM & Generalized Linear Model \\
\hline IES & Impact Evaluation Survey \\
\hline IV & Instrumental Variable \\
\hline KADIN & The Indonesian Chamber of Commerce and Industry \\
\hline MDG & Millennium Development Goals \\
\hline MICI & Monitoring Investment Climate Indicators \\
\hline MIS & Monitoring Information System \\
\hline OLS & Ordinary Least Squares \\
\hline PCA & Principal Component Analysis \\
\hline PNPM & National Program for Community Empowerment \\
\hline PODES & Village Potential Census Data \\
\hline QMLE & Quasi-Maximum Likelihood Estimator \\
\hline $\mathrm{RE}$ & Random Effects \\
\hline RT & Neighborhood \\
\hline RW & Ward \\
\hline SEADI & Support for Economic Analysis Development in Indonesia \\
\hline SUSENAS & Indonesian National Socioeconomic Survey \\
\hline UPP2 & Urban Poverty Project 2 \\
\hline ZEF & The Centre for Development Research, University of Bonn \\
\hline
\end{tabular}




\section{Introduction}

If the central purpose of economics is to understand why and how growth varies across countries and over time, Indonesia is surely one of the best laboratories. (Hal Hill, 1996)

\section{The big bang decentralization}

Over a decade after the Asian economic crisis, Indonesia has started to regain its grip. After a free-fall of the rupiah followed by a spike in inflation, a jump in unemployment and poverty rates, Indonesia is now one of the world's emerging middle-income countries. The road has not been easy. Indonesia has undergone a major political transformation, changing from a highly centralized political system to one of Asia Pacific's most vibrant decentralized democracies.

The implementation of Indonesia's decentralization is dubbed the "big bang decentralization" as it rapidly moved the government from being one of the most centralized systems in the world to one of the most decentralized ones. Prior to decentralization, 94 percent of the country's revenue was collected by the central government, whereas 60 percent of subnational spending was financed by central transfer (World Bank, 2000). This overlycentralized system has caused dissatisfaction from the resource abundant regions, which felt that they were receiving unfair treatment. This dissatisfaction triggered serious threats of disintegration from Aceh, West Papua and East Timor. In order to reduce this tension, the Indonesian government adopted the Regional Autonomy Law and Fiscal Balancing Law, which came into effect in 2000.

The euphoria of decentralization was sparked by transfer of resources, administrative devolution, and the democracy movement. The Fiscal Balancing Law mandated that the central government share the revenue from natural resources in a way that would reflect 
equity with the resource abundant regions. In terms of bureaucracy devolution, the Indonesian government decentralized most public service functions to 292 district governments. This delegation includes the transfer of around 40 percent of government expenditures and approximately 2.4 million civil servants to local governments. Furthermore, since the year 2000, district heads were elected by democratically elected local parliaments, while five years afterwards, they were directly elected by residents. ${ }^{1}$ This democracy movement, which delegates the decision-making process to locals, has created new opportunities for citizens to influence policy and budget decisions. Obviously, the "big bang decentralization" has brought a new set of circumstances to policy makers in tackling social and economic problems.

\section{Involving communities to improve service delivery}

In response to the economic crisis, the Indonesian government also decentralized the administration of anti-poverty programs to local governments or community representatives, including procurement, selection of projects, and identification of beneficiaries. The government of Indonesia formulated a nationwide anti-poverty project named the National Program for Community Empowerment (PNPM), which was claimed to have been one of the largest community-driven development programs in the world that promotes local community participation in the project's implementation.

The idea of decentralizing poverty programs by involving local communities was grounded on the assumption that locals have better knowledge regarding who is poor and what can be done to help them. Still, the overall effects of this decentralization on accountability are still debatable; since they depend on the local institution administer competing interests. These local institutions consist of different stakeholders with different interests, while interaction among them involves compromises in how to allocate and deliver resources. Consequently, a decentralized poverty program can be influenced by local elites, who may alter the nature of the program for their benefit. The process whereby transferred resources intended for the benefit of the poor are captured by a small number of individuals of superior status is defined as elite capture.

\footnotetext{
${ }^{1}$ District level was chosen as the main level of autonomy because the concern from the military at that time that provincial autonomy would enhance the possibility of disintegration (World Bank, 2000).
} 
The available theoretical literature has identified the factors that are related to greater capture of decentralized poverty programs, such as inequality within communities, voter awareness, media attention, and transparency in local decision-making. The basic conclusion of the literature is that: "The contrasting roles of these diverse factors suggest that the extent of relative capture at the local level may well turn out to be context- and system-specific. This creates the need for empirical research to identify the nature of relative capture in any given setting, in order to appraise the potential pitfalls of decentralization" (Bardhan and Mokherjee, 2000). Recognizing this, it is the purpose of chapter 1 to empirically investigate the role of elite capture in the context of an Indonesian decentralized anti-poverty program named the Urban Poverty Project 2 (UPP2), which was part of the PNPM.

Indonesia, the fourth largest country in the world, with more than 300 ethnic groups spread over some 13,000 islands, tends to be not only very heterogeneous but also highly unequal. The available empirical literature shows that in the presence of economic and social inequality, there is an even larger local capture conducted by the elite, who may interfere with decision-making processes, thus diverting poverty targeting (Araujo et al., 2008; Galasso and Ravallion, 2005). Bardhan (2002) argued that in a highly unequal community, collusion may be easier to organize between elites because cooperation between influential people and local government makes the probability of detection very small, and can create barriers to entry for poorer people from participating at all. Nevertheless, Mansuri and Rao (2013) highlighted that the relationship between inequality and elite capture can be ambiguous. They illustrate that in a persistently unequal rural community, where intergenerational poor have engaged in social and economic relations over a long time, collective action may occur if the local leader has an interest in it.

Chapter 1, which is based on joint work with Stephan Klasen, focuses particular attention on evidence relating to whether unequal community income distribution may lead to greater elite capture. The combination of a detailed UPP2 impact evaluation and the UPP2 administrative data allows for an investigation of the link between the structure of power and resource allocation made by the elected representatives of the local body. The second contribution of chapter $\mathbf{1}$ is in identifying the bargaining power of the stakeholders in the local institutions, and examining how it influences the decision-making process. As each stakeholder has a distinct identity and preferences, they tend to balance their own interests with concerns derived from their group identity. Vigdor (2004) shows that individuals behave altruistically toward the community to which they belong, especially if they share characteristics with (the 
majority of) the community. Accordingly, in chapter 1, an elite index is constructed using information from elected community representatives regarding their levels of consumption, education, and social connectedness. This elite index is included in order to capture the degree of the representative's bargaining power in the local decision-making process, and how it might influence the project's resource allocation.

The main finding of chapter $\mathbf{1}$ confirms the negative relationship between community inequality and the allocation of pro-poor projects, which is robust when tested using different inequality measurements and alternative dependent variables. This means that the allocation of pro-poor projects is significantly lower in unequal communities. Another finding is that when representatives in the local institution share the identities of non-elites, the probability that they will allocate more resources toward pro-poor projects increases. Although causality is difficult to establish, these findings thus suggest that the local power structure is an important consideration for poverty-targeting strategies.

\section{Fighting corruption in decentralized Indonesia}

The implementation of a decentralized government system in 2000 was expected to be a means of reducing corruption in Indonesia by bringing the government closer to the people. The government should be more accountable, because it will be subjected to electoral pressure from residents, who are able to monitor service delivery better than the central government (Bardhan, 2000). However, Indonesia's decentralization in fact made local governments act as if they were in a race to increase their incomes. Available studies show that local governments compete to increase revenue by issuing hundreds of new regulations concerning taxes, levies and other fees to regulate business activities (Basri, 2004). Consequently, corruption became less predictable, as compared to the Suharto regime, since the issuance of new regulations leads to the creation of new departments and the hiring of new public officials. Patunru and Wardhani (2008) point out that the bribery rate after decentralization is actually lower, but the number of agents, who need to be bribed, increases. It is, therefore, unclear whether paying bribes will improve the effectiveness of public service delivery.

Chapter 2 elaborates more on the linkages between bribe payments and the effectiveness of public service delivery after the big bang decentralization in Indonesia. The "grease the 
wheels” hypothesis proposes that bribery may speed up a rigid administration by removing barriers to economic activities (Leff, 1964; Leys, 1965; Huntington, 1968; Lui, 1985). However, the hypothesis may not be adequate, given the complexity of the transaction. Bribery is illegal and kept secret, and this makes it uncertain whether the corrupt official will credibly commit to an agreement made during the transaction. Myrdal (1968) and Andvig (1991) argued that a corrupt official may deliberately impose administrative delays in order to attract further bribes.

A number of empirical studies that test the "grease the wheels" hypothesis even reveal a "sand the wheels” effect of corruption. For instance, Kaufmann and Wei (1999), Henderson and Kuncoro (2004), and Fisman and Gatti (2006) use firm-level data and find a positive relationship between the amounts of money spent on bribes and bureaucratic procedures. These studies conclude that firms that pay higher bribes spend more time with public officials to deal with regulations. Even though these results have provided an important alternative to the "grease the wheels" hypothesis, they do not take into account the potential reverse causality relationship, which may result in inconsistent parameters and therefore misleading conclusions.

Acknowledging this, chapter 2 empirically examines the "grease the wheels" hypothesis by using the two survey rounds of MICI data (Monitoring Investment Climate Indicators), which contain information about the experiences of firms with bureaucrats in Indonesia. Given the advantage of the panel data structure, the lagged value of bribes is used to instrument the current bribes. Since the instrumental variable chosen is predetermined, applying the 2SLS approach may provide a consistent parameter. As a result, chapter 2 further confirms the positive relationship between the amounts spent on bribes paid and managerial contact time with officials. In this respect, chapter 2 complements the previous research that has examined this specific issue.

A second contribution of chapter $\mathbf{2}$ in relation to the literature is its assessment of the "grease the wheels" hypothesis within the context of competitive bribery and imperfect information. As in a sealed auction, none of the firms know the amounts of bribes paid by their competitors. Accordingly, each firm will offer bribes based on its belief about the value that will be required to reduce bureaucratic delay. On the other hand, a corrupt official has full information of the bribes paid by all firms, as well as firm characteristics. This information allows the official to estimate the expected values of bribes from each firm. Chapter 2 demonstrates that when companies bribed above their expected bribes value, they might be 
labeled as "weak" firms by officials, leading corrupt officials eventually to extend bureaucratic delays. These results affirm the counter-productive effect of bribes, which supports the anti-corruption campaigns promoted by governments and international organizations.

\section{The role of female policy makers}

Another challenge faced by the Indonesian government after decentralization is ensuring that every group of the population is represented in the decision-making process. One year after the passing of the Decentralization Law in 1999, the Indonesian president issued presidential instructions on gender mainstreaming, which directed all government ministries and agencies at the national and local levels to adopt a gender mainstreaming strategy in implementing development policies. One of the results was that women's representation in the national legislatures increased significantly, from around 9 percent to about 11.3 percent in the 2004 elections, and 18 percent in the 2009 elections. Furthermore, a quota law has been passed in 2009, requiring that women make up 30 percent of political candidates for legislative positions.

The importance of the women's political reservation policy derives from the argument that women have different political interests from men, as expressed in their voting and leadership behavior. Therefore, active female participation in the decision-making process is expected to produce development outcomes that are more responsive to women's needs. However, little is known about whether women representatives accommodate the preferences of their female electorates.

The well-known median voter theory predicts that if democracy is perfect, the winner of a political election will be the candidate whose platform represents the preferences of the median voter. On this theory, mandating a woman as a candidate would not necessarily matter. However, a politician can only enact a policy commitment once she is in office. It is still uncertain whether the politician will credibly commit to the voter's preferences if those preferences oppose the politician's interests. In an alternative economic model of representative democracy (the citizen candidate model), Besley and Coate (1997) and Osborne and Slivinski (1996) propose to relax the assumption of complete policy 
commitment, by allowing for the role of the politician's identity, including their gender, as an important factor in policy outcomes.

Most of the available empirical studies that test the role of gender on policy outcomes focus on how gender shapes voting behavior (Edlund and Pande, 2002; Alesina and La Ferrara, 2005; Lott and Kenny, 1999; and Svaleryd, 2009), or on how female politicians influence political outcomes (Rehavi, 2007; Bhalotra and Clots-Figueras, 2013). There are only a few studies that analyze the relevance of differences of preferences between male and female voters under indirect democracy, and relate this to the differences in preferences between male and female politicians, and how these factors simultaneously influence policy outcomes. If females and males have different preferences, female politicians may (or may not) make different policy choices than male politicians. In other words, if female politicians' preferences were the same as their male counterparts, a women's reservation policy would not be necessary. It is thus critical to identify the gender gap in the preferences of both voters and politicians, in order to improve our understanding regarding the effectiveness of female empowerment in politics.

Acknowledging these shortcomings, chapter 3, also the result of joint work with Stephan Klasen, discusses the role of women as decision makers in the context of Indonesia's decentralized anti-poverty program, UPP2. In particular, chapter 3 examines whether the project resource allocation of UPP2 is more responsive to women's preferences when there is a higher number of women representatives in the local institution. Chapter 3 begins by testing the median voter theory, then analyzes the role of gender composition in the local representative body, and of the gender gap in preferences, in shaping policy outcomes.

Using rich data on ex-ante preferences of both voters and politicians, it finds that in most cases, the preferences of the median voter do not matter for policy outcomes, but in some cases they do. It shows that the proportion of the budget allocated to education, health and irrigation programs is higher in communities where the median voter raises issues related to these particular programs. Furthermore, chapter $\mathbf{3}$ reveals that the proportion of representatives who are female is irrelevant for policy outcomes, but does facilitate accommodating the preferences of the median voter, and particularly the preferences of female voters who request more attention to public sanitation. It is argued that the effect of female representatives is small because female representatives' preferences differ from those of their male counterparts only on issues related to public sanitation, but not more generally. In the case of UPP2, the similarities in preferences of male and female representatives may be 
driven by the fact that both groups come from the highest qualified communities, with the similar high level of education, higher consumption per capita, and more social connectedness. Still, the findings of chapter 3 that show that the gender of the policy maker matters cast doubt on the prediction of the median voter theory that only the preferences of the median voter determine public policy outcomes.

\section{Policy implications}

The three chapters of this thesis contribute to the understanding of the Indonesian political economy in the era of decentralization. They all confirm that institutions and their stakeholders matter for development outcomes. One of the main findings of the study is that community inequality is an important determinant of pro-poor targeting policies. In this context, elite capture, characterized by a community allocating spending that would not have been favored by the poor, is evident in more unequal communities. This finding is relevant to the hundreds of community-driven development (CDD) programs currently in operation in developing countries. The implications are not necessarily that CDD or participatory approaches are not working. Instead, the findings suggest that policy makers should put more emphasis on the resilience of the local power structure and the decision-making process, and on the consequent need for pro-poor initiatives, in order to ensure that the program's targeting focuses on the poor.

Furthermore, one of the findings also highlights that the rent-seeking activities of corrupt officials becomes less predictable after decentralization. It is found that paying higher bribes to public official increases, rather than decreases, the share of managerial time spent with officials. This finding is not only good news that supports the anti-corruption act; it also implies that economic agents should consider the effects on both the level and efficiency of bribe transactions. For policy makers, this may include, among other things, simplifying bureaucratic procedures, reducing human contact in bureaucratic transactions, or regularly rotating public officials' posts. Moreover, any anti-corruption strategies would not be effective without the support of credible and independent law enforcement, as well as the support of the judiciary and police in providing supervision of officials who administer the delivery of public services.

Finally, chapter 3 examines the role of women elected as local representatives in the local institution established by UPP2. It finds that women's representation is important in 
accommodating the preferences of female voters. This finding is pertinent in the context of the women's reservation policy that is increasingly implemented at various levels of government. In Indonesia, the desired quota of women political candidates has never been met, due to the low rate of women's participation in social and political activities, especially in leadership positions. Given our results, policy makers should pay closer attention to improving women's participation in politics, which can be manifested in increasing women's capacities and capabilities, enhancing political awareness in local governments, and strengthening organizations mandated to address gender issues. 


\section{Elite capture in urban community-driven development: Evidence from Indonesia ${ }^{2}$}

\section{Abstract}

It has been argued that the potential gains of community-driven development (CDD) poverty programs are significant as these can foster sustained poverty reduction. However, the literature shows that community involvement can increase the risk of elite capture, particularly in more unequal communities where the gap between the poor and the non-poor is larger, making it more difficult for the poor to increase their bargaining power and voice their preferences. In this paper, we examine the link between elite capture and inequality within the context of CDD programs. Using data sets from a nationwide CDD program in Indonesia, the Second Urban Poverty Project, we find robust evidence that less equal communities are less likely to receive pro-poor projects. It also finds that the probability of receiving a higher share of pro-poor projects increases when policymakers share similar characteristics with the locals who have low levels of education, consumption, and social networks.

\footnotetext{
${ }^{2}$ This paper is based on joint work with Stephan Klasen.
} 


\subsection{Introduction}

Community-driven development (CDD) has become a common mechanism for decentralizing anti-poverty programs. The CDD approach works by promoting community involvement in project implementation, as it is assumed that locals are best able to understand prevailing local conditions, capacities and necessities, and are best suited to identifying the genuine poor. ${ }^{3}$ In their comprehensive review on participation and development, Mansuri and Rao (2004) advocate that the potential gains from involving local participation are large. For instance, it helps to enhance poverty targeting, creates social capital, and improves the public service delivery. It is expected that this approach can minimize rent-seeking behavior that will lead to an equal resource allocation and sustain poverty reduction since it will be subjected to local pressure from residents, who are able to monitor service delivery. However, many critics note that community-driven development initiatives may trigger a local capture. Given the fact that the local participants have more information than the donor, people at the top of the community distribution may exploit such information for their benefit at a cost to the poor, making the CDD approach counterproductive. Mansuri and Rao (2013) further argue that in a participatory process, the poor have a higher opportunity cost to participate in civic activities than the better off, who are wealthier, more educated, have higher social status, are male, or have higher social connections. As a result, the poor may benefit less from social programs since the resource allocation processes may reflect the preferences of the elite group. In an empirical work, Lanjouw and Ravallion (1998) showed that the poor who are located in remote areas with limited information have difficulties in accessing the program benefits, as these benefits are first captured by the non-poor who argue that they are entitled to the benefits in exchange for their tax payments. Further studies show that a malevolent elite engagement that abuses its power to influence the local decision-making process thus alters the nature of social programs for the benefit of the elite, are more likely to occur in certain contexts (Bardhan and Mookherjee, 2000; Platteau, 2004; Conning and Kevane, 2002; Araujo et al., 2008).

Over the past decade, studies of elite capture have focused on the role of elite capture in unequal setting. The existing theoretical literature shows that the relationship between local capture and inequality is complex, without a clear pattern that the link is not necessarily

\footnotetext{
${ }^{3} \mathrm{~A}$ CDD program typically involves the establishment of local non-government institutions made up of local representatives who are responsible for allocating project resources through anti-poverty actions responding directly to the needs of the poor.
} 
monotonic, and can be U-shaped (Bardhan, et al., 2000; Dayton-Johnson and Bardhan, 2002). These theoretical works conclude that the correlation between the two variables can be context specific, and suggest the need for further empirical research to identify the nature of elite capture under different conditions and settings.

In view of this, several works have attempted to empirically study the relationship between inequality and local capture, but not abundant. Galasso and Ravallion (2005) show that in Bangladesh's Food for Education Program, higher inequality in land holding reduces allocation to the poor due to the greater power of local elites. Using data from 66 communities participating in a CDD projects in the Philippines, Labonne and Chase (2009) match the exante community preferences with actual funded projects. They report that in unequal communities a village leader is more likely to override community preferences. Platteau, (2003) argues that the reason why elite capture can be more likely to occur in less equal communities is because inequality may increase conflicts of objectives among locals, who each tend to promote their own agenda, so that people at the top of the distribution do not hesitate to exploit the information gap between donors and communities, ensuring that the poor at the bottom of the distribution find it difficult to voice their own preferences. The findings of Alesina and La Ferrara (2000) are in line with these grounds, demonstrating that inequality lowers the incentive for participation and group interaction, discourages groups from making decisions by voting, and therefore lowers group performance.

In this paper, we investigate the role of elite capture within the context of the World Bank's Urban Poverty Project 2 (UPP2), which was implemented between 2004 and 2007 in Indonesia. Using a CDD approach, the UPP2 required every community to establish a Board of Community Trustee (Badan Keswadayaan Masyarakat, hereinafter referred to as BKM). Every BKM consists of 9-14 elected community representatives who were responsible for managing the UPP2 resource allocation. This paper particularly examines the project allocation pattern when the locals are unequally distributed. Using a unique combination of UPP2 impact evaluation and project administration data, we find that less equal communities are less likely to receive pro-poor projects.

Furthermore, we analyze how the bargaining power within BKM influences the project resource allocation. As representatives have a distinct identity and preferences, they tend to balance between their interests and the interest that derives from their group identity. Vigdor (2004) shows that individuals behave altruistically toward the community they belong to, especially if they share similar characteristics with (the majority of) the community. His study 
examined the individual's decision to return the Census questionnaire by mail, and showed that individual responses depend on how much the individual internalizes the benefit bestowed on the community at large. The similarity between individuals in terms of age, education and race in a community determines the internalization of the benefit. In this paper, we compute the elite index of each BKM member based on their level of education, consumption, and social networks. Our analysis finds that when BKM members are dominated by representatives whose characteristics are closer to the non-elites, the chances of choosing a pro-poor project increases.

This paper proceeds as follows. The second section discusses the UPP2 and its delivery mechanism. Section 3 presents the empirical strategy. Section 4 provides the research data and statistics. Section 5 presents the empirical results. Finally, in Section 6, the main results are summarized, and conclusions are drawn.

\subsection{The Urban Poverty Project 2}

The Urban Poverty Project 2 (UPP2) is part of the Indonesian National Program for Community Empowerment (PNPM), one of the largest community-driven development poverty alleviation programs in the world. PNPM was launched to response the Asian Financial crisis took place in 1997-98 that during the crisis, Indonesia experienced massive capital outflows with numerous companies cutting back production and declaring bankruptcy, passing to a spike in unemployment rates and thus poverty incidences. As a result, the number of people living under the poverty line increased significantly, especially those living in urban areas, who were more exposed to the crisis.

UPP2 was approved in 2002 and implemented between 2004 and 2007. The project expanded the UPP1, the precursor coverage area, to the southern part of Java, Kalimantan, Sulawesi and West Nusa Tenggara. In total, the US\$127 million project targeted 2,058 urban kelurahans spread over 13 provinces, where the selection of the participating kelurahan was based on a composite poverty score computed at the sub-district level using socioeconomic and demographic variables from the village potential census data (PODES). ${ }^{4}$ The size of the

\footnotetext{
${ }^{4}$ Indonesia is divided into 33 provinces, which in turn are composed of districts. Each district is further broken down into sub-districts. Below the sub-district level, there are villages and urban villages called kelurahan. Typically, a kelurahan is divided non-administratively into several neighborhoods (RW) that consists of several wards (RT). Each ward manages a certain number of households.
} 
awarded grant per kelurahan depends on population size and poverty density. For instance, a kelurahan with population of less than 3,000 people could access grants up to US\$16,600, while a kelurahan with population of between 3,000 and 10,000 could access up to US $\$ 27,700$ and those with more than 10,000 people could receive up to US\$55,400. Poverty density also determines the amount of the grant received. If there were 300-1,000 poor households in a kelurahan with a population of less than 3,000, the grant would be adjusted to US\$27,700. Likewise, if there were more than 1,000 poor households in a kelurahan with 3,000 to 10,000 people, the allocation could rise to US\$55,400.

Using CDD approach, UPP2 capitalized on the Indonesian tradition of gotong royong or mutual assistance among residents in development activities. UPP2 required every beneficiary community to set up a local community board, the Badan Keswadayaan Masyarakat (community board trustee, BKM), consisting of 9-14 elected community representatives or board members. These representatives were delegated the authority to manage and implement the project resource allocations, including selecting potential beneficiaries and types of action for poverty alleviation.

Given the important role of BKM members, the election mechanism was conducted in several stages. Before the grants were disbursed, the UPP2 facilitators invited residents in the neighborhood (one level below kelurahan) to attend a neighborhood meeting. The facilitators guided a discussion about the qualities that a leader should have, and asked them to identify people in the neighborhood who possessed such qualities. The names of the candidates were then collected and sent to the kelurahan. The residents were then invited to kelurahan meeting to vote for BKM board members through a secret ballot. As a result, the winners of the election served as unpaid BKM members. ${ }^{5}$

Once BKM was established, the elected members led a community discussion among kelurahan residents to formulate a community development plan (CDP). In general, it was expected that the CDP would include pre-identified investments covering a range of poverty alleviation activities, depending on the local circumstances. The local residents could also choose to allocate part of the resources to revolving fund projects, where recipients are required to repay the loans at low interest rates to maintain the project's cash flow. The project document stated that revolving fund projects were mainly targeted at the non-poor,

\footnotetext{
${ }^{5}$ Communities may also opt to form a BKM institution by strengthening the existing local organization, as long as the members were chosen democratically and in a participatory manner.
} 
with profitable business opportunities and sufficient repayment capacities yet have no other access to credit. However, these non-revolving fund projects were expected to create a multiplier effect for the poor. Furthermore, for projects that were not listed in the CDP, communities could submit project proposals to be assessed by BKM. ${ }^{6}$ Subsequently, the list of poverty programs collected from both community discussions and submitted proposals were then discussed by BKM members to assess and executes. Fieldwork showed that most BKM decisions were made through discussion, but voting also occurred.

\subsection{Empirical strategy}

In this paper, we analyze the pattern of project types received in each community and associate this with the level of community inequality in terms of household consumption. Our empirical model is based on the Araujo et al. (2008) who analyze the project allocation patterns in Social Fund investment projects in Ecuador. The model explains a situation where a social program provides two types of projects: public good projects and private good projects. Private good projects are basic necessity projects that exclusively provide for the poor and cannot be consumed by the non-poor at the same time. In contrast, public good projects, which share the characteristics of public goods, are non-excludable and "non-rival" as these can be consumed simultaneously by everyone.

Given the two types of projects, the rational poor would prefer private good projects as these directly benefit them and meet their basic necessities while the non-poor would prefer public good projects since they can only reap the benefit of the project from these projects. In this study, we assume that private good projects can only be consumed by the poor since the nonpoor have no interest towards private good projects because basic goods are less needed by the non-poor, or they would be excluded from receiving such projects. Based on this definition, we define the occurrence of elite capture in poverty programs is when the non-poor succeed in influencing local decision-making and alter the nature of poverty programs to choose more public good projects rather than private good projects. ${ }^{7}$ Furthermore, the poor

\footnotetext{
${ }^{6}$ For some extremely high cost projects, financing could be combined from UPP2 funds, local government budgets and/or private donors. Community contribution of materials, labour, or land was also possible.

${ }^{7}$ We further assume that (1) there is no mistargeting in the program implementation, that is the non-poor received private good sub-projects and (2) there is no externality associated with private good projects, i.e. that the non-poor's utility will not increase if the poor received private good sub-projects.
} 
may find it more difficult to increase their bargaining power in unequal communities, where the gap between poor and non-poor and between powers is large.

Based on this, we hypothesize that the community inequality tends to increase elite capture so that the community will choose fewer private good sub-projects compared to public good subprojects. Thus, the following cross-section model is estimated:

$$
P_{i j}=\alpha_{0}+\beta_{0} I_{i j}+\beta_{1} Y_{i j}+\beta_{2} G_{i j}+\beta_{3} X_{i j}+\mu_{j}+\varepsilon_{i j}
$$

Here, the dependent variable, $P_{i j}$, stands for the share of private good projects per total projects received by kelurahan $i$ in the district $j$. The main variable of interest is the kelurahan inequality, $I_{i j}$, which is computed from the consumption of 32 randomly selected households in every community. ${ }^{8}$ We assume that the political power is positively correlated with economic status. In equation (1.1), the elite capture hypothesis is confirmed when the parameter $\beta_{0}$ is negative, which means that higher inequality is associated with a smaller share of private projects received by kelurahan $i$, holding other variables constant. Our specification controls for the mean consumption of the kelurahan $\left(Y_{i j}\right)$ that represents the prosperity level and the pre-existing local public goods $\left(G_{i j}\right)$. In addition, the model controls for another community level determinants $X_{i j}$ that might affect the project selection. Finally, district fixed effects $\mu_{j}$ are included.

The second objective of this paper is to analyze the role of each board member's bargaining power on project choice. To do this, we construct an "elite index" for each board member in every BKM. We assume that the elite status is positively correlated with the combination of the level of education, consumption, and social connectedness. Therefore, we use principal component analysis (PCA) to compute the elite index for every BKM member. We further assume that the bargaining power of each BKM member is increasing with elite status.

Based on this index, we categorize a BKM member into one of the two categories: BKM member with elite status and BKM member without elite status. ${ }^{9}$ Let $S_{m}$ denotes the elite status of BKM member $m$, thus the categorization can be written as follows:

\footnotetext{
${ }^{8}$ Given that variable inequality is computed based on the consumption of randomly selected 32 households, the extent of attenuation bias might be an issue. However, in the estimation results we show that the attenuation bias, which usually causes the estimated coefficient to be insignificant, is not really a problem.

${ }^{9}$ Given that we define elite as people at the top of the distribution, we use the cut off for categorizing elite status if the "elite index" is one standard deviation above the mean.
} 


$$
S_{m}= \begin{cases}1 & \text { with elite status } \\ 0 & \text { no elite status }\end{cases}
$$

Subsequently, we analyze BKM decision-making process by examining the composition of the board member's elite status in BKM.

Although every BKM consists of 9-14 board members, the UPP2 impact evaluation survey only interviewed three BKM members: one male member, one female member, and one coordinator. As a result, the elite index can only be computed for the three available BKM members. Using this information, the possibility of elite status composition in every BKM can be described as follows in Table 1.1:

Table 1.1 The composition of elite status of BKM members

\begin{tabular}{|l|c|c|c|}
\hline BKM type & $S_{1}$ & $S_{2}$ & $S_{3}$ \\
\hline Homogeneously high $\left(\mathrm{Hm}^{h}\right)$ & 1 & 1 & 1 \\
Heterogeneously high $\left(\mathrm{Ht}^{h}\right)$ & 1 & 1 & 0 \\
Heterogeneously low $\left(\mathrm{Ht}^{l}{ }_{i}\right)$ & 1 & 0 & 0 \\
Homogeneously low $\left(\mathrm{Hm}^{l}{ }\right)$ & 0 & 0 & 0 \\
\hline
\end{tabular}

Note: Based on the information from three BKM members.

Based on this, we classify each BKM into four types of BKM based on the composition of elite status hold by the members and include these categories in the empirical model as dummy variables. $\mathrm{Hm}^{h}{ }_{i}\left(\mathrm{Hm}^{l}\right)$ is a dummy variable for BKM for which all sampled members have homogeneously high (low) elite status. While $\mathrm{Ht}^{h}{ }_{i}\left(\mathrm{Ht}^{l}{ }_{i}\right)$ is a dummy variable for BKM with the majority of board members have high (low) elite status. Including these dummy variables in the model, equation (1.1) reads:

$P_{i j}=\alpha_{0}+\delta_{1} H m_{i j}^{l}+\delta_{2} H t_{i j}^{h}+\delta_{3} H m_{i j}^{h}+\beta_{0} I_{i j}+\beta_{1} Y_{i j}+\beta_{2} G_{i j}+\beta_{3} X_{i j}+\mu_{j}+\varepsilon_{i j}$

In equation (1.2), elite capture exists when $\delta_{2}$ and/or $\delta_{3}$ is negative, that is if BKM has more board members with elite status, the lower the share of private good projects received by community $i$. 
As the dependent variable is in fraction and continues, with values bounded between 0 and 1 , estimating the model with a logit or probit method will produce an unnecessarily transformed dependent variable into binary form (zero or one). Moreover, using the OLS estimator would be incorrect and not be constant through the entire range that the predicted value is more likely to have values outside the range of zero to one. Therefore, equation (1.1) and equation (1.2) are estimated using the fractional logit method as suggested by Papke and Wooldridge (1996). Using this method, the model extends the generalized linear model (GLM) and shows that the quasi-maximum likelihood estimator (QMLE) is a consistent estimator, as long as the assumption of the conditional mean function is correctly specified.

\subsection{Data}

This study combines two data sets from the Monitoring Information System (MIS) and the Impact Evaluation Survey (IES), both collected by the World Bank. The MIS is a web-based information system that reports project's deliverables, while the IES contains kelurahan level information gathered from several respondents: household members, BKM members, kelurahan head, the local activist, etc. Combining the MIS and IES using the survey code and the kelurahan name, this study is able to match 154 kelurahan for the empirical analysis. ${ }^{10}$

\subsubsection{Monitoring Information System}

The Monitoring Information System data (MIS) report information about the project deliverables in every UPP2 kelurahan. The data contain both the number and the cost of projects received by every community, which is further classified into several programs. In the report, the MIS data begin by classifying the accomplished projects based on the disbursement mechanism: revolving fund projects and non-revolving fund projects. In the later mechanism, the recipients were required to repay the loans at low interest rates to maintain the project's cash flow. Table 1.2 describes the UPP2 project classification based on the MIS data. Each project mechanism is broken down into three general sectors:

\footnotetext{
${ }^{10}$ The MIS data contain 2,059 kelurahan while the UPP2 impact evaluation data contains of 256 kelurahan where 98 of them are control kelurahan. Fort the purpose of this study, we only use the treatment kelurahan.
} 
infrastructure, social, and economic sector where every sector is further classified into several programs.

Table 1.2 Classification of UPP2 projects based on MIS data

\begin{tabular}{|c|c|c|}
\hline Sector & Program & Program description \\
\hline \multirow{5}{*}{ Infrastructure } & Roads/bridges & New construction or rehabilitation of roads/bridges. \\
\hline & House improvement & Construction or rehabilitation of residential house. \\
\hline & Public sanitation & Drainage, public toilets, garbage/waste facilities for community level. \\
\hline & Public utilities & $\begin{array}{l}\text { Construction or rehabilitation of community's clean waterways, water tank, } \\
\text { public lighting, etc. }\end{array}$ \\
\hline & Infrastructure - others & Infrastructure related projects that do not fit the above criteria. \\
\hline \multirow{3}{*}{ Social } & Trainings & Support for trainings or informal education to improve the poor's skill. \\
\hline & Social assistance & $\begin{array}{l}\text { Grant assistance to the specific individuals identified as being the most } \\
\text { vulnerable, which include the support for orphan, elderly, the poor, in the } \\
\text { form of scholarships, health care, etc. }\end{array}$ \\
\hline & Social - others & Social related projects that do not fit the above criteria. \\
\hline \multirow{3}{*}{ Economic } & Home industry & $\begin{array}{l}\text { Small scale manufacturing support (i.e. small scale shoes factory, clothing, } \\
\text { handbags, pottery, etc. }\end{array}$ \\
\hline & Micro retail & $\begin{array}{l}\text { Petty trade support, such as selling cooked/fresh food, services such as } \\
\text { electronics repair, tailoring, etc. }\end{array}$ \\
\hline & Economic - others & Economic related projects that do not fit the above criteria. \\
\hline
\end{tabular}

In Figure 1.1, the distribution of UPP2 projects is presented where the number and the cost of projects are described in the left and right panel, respectively. It can be seen that the number and cost of microfinance programs are the largest, followed by road/bridge program and social assistance. These programs were delivered by using two mechanisms: non-revolving fund and revolving fund. Figure 1.1 shows that most of the revolving fund projects fall under economic sectors (96 percent), particularly in the form of microcredit loans for community groups, which usually used to finance income generation activities, such as petty trade, selling cooked/fresh food, and services such as electronics repair, tailoring, and small-scale manufacturing of shoes, clothing, handbags, pottery, etc. 
Figure 1.1 Distribution of UPP2 projects by project’s cost and quantity, 2004-2007

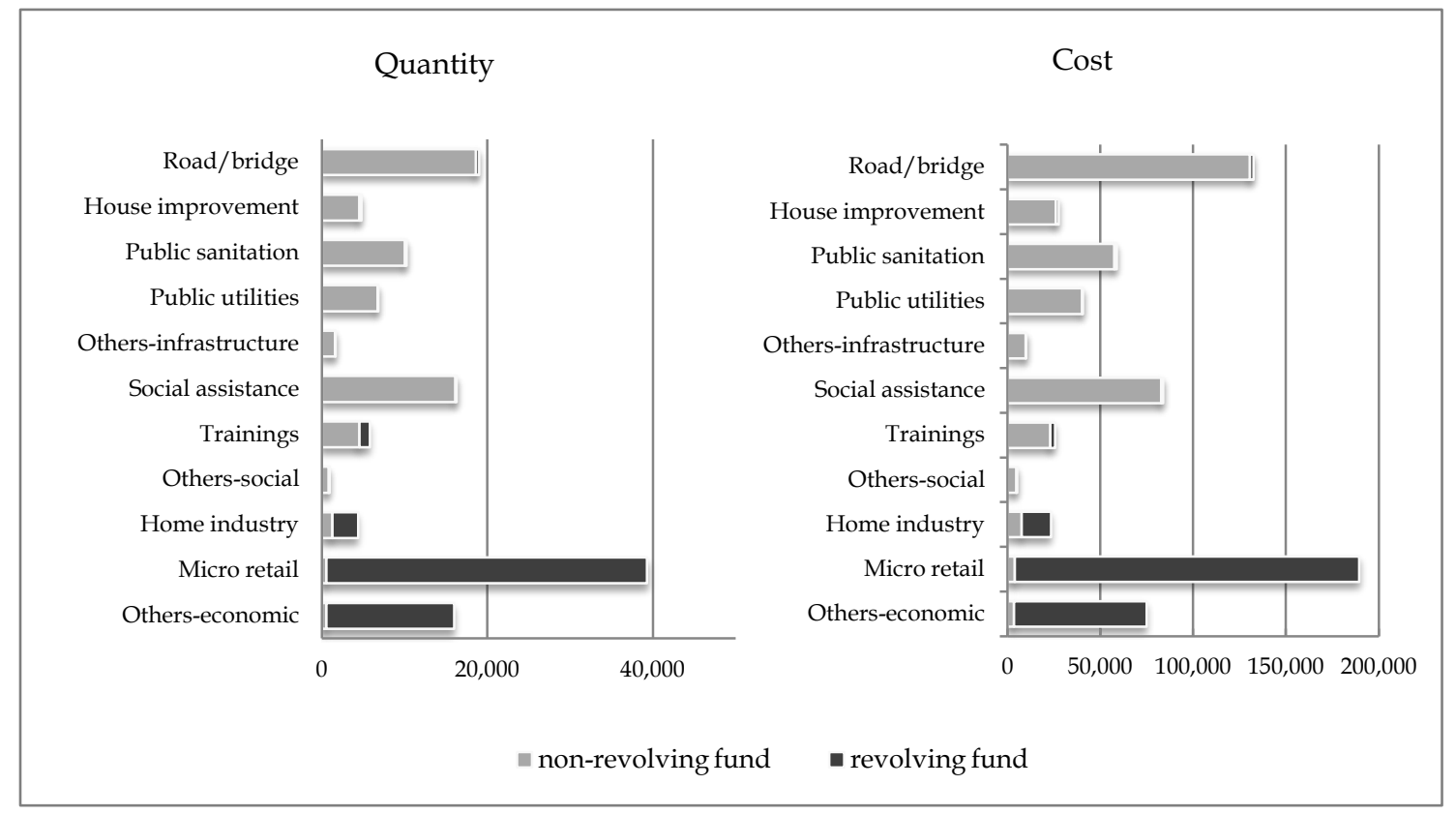

Notes: Calculated based on 2,059 kelurahan in MIS data. The project costs in million rupiah.

For the purpose of this study, we focus to the analysis in the following way. First, we focus on the distribution of non-revolving fund projects, since the targeting of the revolving-fund projects may be biased to the non-poor. Nonetheless, we will also incorporate the revolvingfund projects for robustness checks that will be explained in the later part of this paper. Second, as we define the incidence of elite capture when a community receives a lower proportion of private good projects rather than public good projects, we classify UPP2 programs into private and public good projects. Private good projects consist of social assistance, training, housing improvement, and the support for the unemployed to start small businesses, while public good projects consist of road/bridge, public sanitation and public utilities. ${ }^{11}$ In the third strategy, we use the cost of projects rather than the number of projects to compute the share of private good projects received by every community. Although the quantity of projects received by every kelurahan is a reliable measurement to analyze the pattern of project allocation made by every BKM, but it does not reflect the actual project scale and therefore is incomparable across projects and kelurahans. ${ }^{12}$

\footnotetext{
${ }^{11}$ For instance, the construction of a road/bridge intended to open access to poor households in a remote area will not only benefit the poor but also households located around the road/bridge.

${ }^{12}$ Araujo et al. (2008) only use project quantity data as the project funding data for Social Fund investment projects in Ecuador is unreliable.
} 


\subsubsection{Impact Evaluation Survey}

The second data source of this study comes from the Impact Evaluation Survey (IES), which was conducted to measure the impact of UPP2 on poverty reduction. Designed as a quasiexperimental survey, the data collection was conducted in three rounds: baseline (2004), midterm (2005-2006), and final (2007). For the purpose of our analysis, we utilized the baseline and midterm rounds, which contain community information from the time before the program took place, and immediately after BKM institution was established but prior to the funding disbursement.

In the sample design, the IES used the regression discontinuity method to select the control and treatment kelurahan. The treatment sample was selected using the poverty score computed at the sub-district level, where the richest 20 percent of sub-districts were excluded. Using regression discontinuity, the kelurahan located in sub-districts with a poverty score slightly above the cut-off were assigned as control sample, while kelurahan located in subdistricts with poverty scores slightly below the cut-off were assigned as treatment sample. Given the objective of this study, we only focus on the treatment sample.

In the baseline survey, 32 households in every kelurahan were randomly chosen for the enumerator to collect information from one adult male and one adult female. ${ }^{13}$ The survey gathered socio-demographic information about household members, as well as household expenditure and the social network of the two adults. Information on food and non-food expenditure of every household are used to compute kelurahan average consumption and inequality measurements.

Immediately after BKM was established, the midterm data were collected. In this survey, an additional module was given to all 1,920 BKM board members to record their sociodemographic backgrounds, such as gender, education, employment status, etc. Of the 1,920 BKM members interviewed, the survey randomly selected three BKM members (one female,

\footnotetext{
${ }^{13}$ The UPP2 sampling design can be described as follows. Strata are defined by provinces where 10 out of 12 UPP2 provinces that have a list of treatment and control sub-districts were selected. From each stratum, 42 UPP2 sub-districts that have both treatment and control sub-districts were randomly selected as the treatment sample, while 29 control samples were representatively selected. In each control and treatment sub-district, half of the total number of communities was randomly selected, resulting in 98 control communities and 157 treatment communities. In each selected kelurahan, the survey carried out the household questionnaire in four neighborhoods, one the neighborhood in which the kelurahan office is located, and the other three randomly selected. Finally, 32 households were randomly selected in every kelurahan.
} 
one male and one BKM coordinator) to collect information on per capita expenditure and their social networks. The sample design of UPP2 is presented in Table 1.3.

Table 1.3 Sampling framework

\begin{tabular}{llrr}
\hline Respondents & Module & \multicolumn{2}{c}{ Total sample } \\
\hline Head of kelurahan & Community profile & Baseline & Midterm \\
\cline { 2 - 3 } Households & Ethnicity, language, etc. & 159 & 154 \\
All household members & Demographic variables & 5,046 & 4,588 \\
Two adults in a household & Consumption and social network & 23,192 & 8,239 \\
All BKM members & Demographic variables & 9,447 & 1,920 \\
Three selected BKM members & Consumption and social network & - & 420 \\
\hline
\end{tabular}

The descriptive statistics of the control variables for the empirical analysis are presented in Table 1.4. The average monthly per capita consumption of UPP2 sample is 219,264 rupiah, which is a little less than the calculation of SUSENAS 2003, which is 225,916 rupiah. Furthermore, the average Gini coefficient of UPP2 sample is 0.33, similar to the Gini coefficient of urban areas in Indonesia calculated by SUSENAS 2003 (SEADI, 2013). This Gini index, which measures the extent to which the distribution of consumption among households deviates from a perfectly equal distribution, is our main variable to capture the distribution of power in the community. Additionally, we also calculate alternative inequality measurements, such as the deciles dispersion ratio, the GE index and the Atkinson index, for further sensitivity checks.

Table 1.4 Descriptive statistics of the variables used

\begin{tabular}{lccc}
\hline Variable & Mean & Median & $\begin{array}{c}\text { Standard } \\
\text { Deviation }\end{array}$ \\
\hline Mean per capita consumption (in rupiah) & 219,264 & 198,121 & 94.28 \\
Population & 5,821 & 4,647 & 3,817 \\
Number of Mosques & 6 & 5 & 5.5 \\
Access to public electricity & 0.96 & 1.00 & 0.12 \\
Distance to central bus station (in minutes) & 14.95 & 10.00 & 13.33 \\
$\mathrm{P}_{8050}$ & 2.76 & 2.51 & 1.67 \\
$\mathrm{P}_{8020}$ & 5.62 & 4.84 & 3.76 \\
Gini index & 0.33 & 0.32 & 0.09 \\
GE index & 0.20 & 1.62 & 0.16 \\
Atkinson index & 0.17 & 0.15 & 0.17 \\
\hline Note: The table is calculated based on 154 sample kelurahan. & &
\end{tabular}


Table 1.5 Comparison between BKM members and the general population

\begin{tabular}{lcc}
\hline Characteristics & BKM members & General population \\
\hline Age & 42.83 & 39.02 \\
Female & 0.19 & 0.51 \\
Married & 0.91 & 0.69 \\
Muslim & 0.91 & 0.92 \\
Employed & 0.80 & 0.53 \\
Hours work per week & 41.69 & 44.55 \\
Years of schooling & 13.00 & 9.32 \\
Education category 0 & 0.00 & 0.00 \\
Education category 1 & 0.03 & 0.34 \\
Education category 2 & 0.08 & 0.18 \\
Education category 3 & 0.46 & 0.35 \\
Education category 4 & 0.42 & 0.13 \\
Social network & 0.63 & 0.92 \\
Per capita consumption & 395,460 & 207,945 \\
N (individuals) & 1,920 & 15,073 \\
\hline Non: Age bew 18 is dra
\end{tabular}

Notes: Age below 18 is dropped, as UPP2 restricts BKM member below 18. Category 0 means never had been in school, 1 for primary school, 2 for junior high school, 3 for senior high, and 4 for university/diploma. The board member's consumption level is measured using 462 samples, where outliers and zero values were dropped.

As BKM institution is the entry point of the CDD approach, we are interested in comparing the characteristics of BKM members and the general population that are eligible to be elected as a BKM member. Table 1.5 shows that BKM members are overwhelmingly male, and coming from the top of community’s socioeconomic distribution. Although a 30 percent quota was the target for women in BKM, only 19 percent of BKM members are females, compared to 51 percent in the general population. Furthermore, the board members spent on average 13 years in school, while for the general population, it is only 9.32 years. It can be seen that around 46 percent of BKM board members have a diploma degree, while only 13 percent of the general population who do. In terms of per capita consumption, 83 percent of BKM members come from the high consumption group, compared to only 26 percent in the general population. ${ }^{14}$ Furthermore, we define social network as a percentage of people in the local government or local institution that an individual knows personally. The table shows that 92 percent of BKM members are networked using this definition, higher than the 63 percent reported by the general population. ${ }^{15}$ From the comparison, it appears that high qualified community members were chosen as BKM members.

\footnotetext{
${ }^{14}$ The calculation of per capita consumption is based on the baseline survey, where the expenditure of the board members at baseline was predicted. Assuming that assets would not vary significantly between baseline and midterm survey, general population's expenditure at baseline is estimated using their assets information. Then, the estimated coefficients are used to predict the expenditure of board members at the baseline survey, using their assets information collected at the midterm' survey. In this study, we use the consumption per capita at the baseline survey because these were not yet affected by the program.

${ }^{15}$ For BKM members, the social network variable was collected when they are available at the midterm survey, while for non-members, at the baseline. Obviously, one can argue that BKM board members have higher social
} 


\subsection{Estimation results}

Table 1.6 presents the estimation result of the specification (1.1), which examines the relationship between kelurahan inequality and the portion of the budget allocated to private good projects. The regression results show that inequality is significant and negatively associated with the dependent variable, which implies that, the more unequal a community's consumption, the smaller the share of private good projects. Thus, this finding supports the hypothesis that elite capture is more likely to exist in an unequal power distribution setting.

To ensure the result consistency, we use several inequality measures with different sensitivities in different parts of the distribution. In column 1 and 2 of Table 1.6, we use the deciles dispersion ratio, which is the ratio of the average consumption of the richest group divided by the average consumption of the poorest, useful for a small sample as in our case. In column 1 we use $\mathrm{P}_{8020}$ or the ratio of the average richest 20 percent divided by the average poorest 20 percent. The econometric result shows that one standard deviation increases in $\mathrm{P}_{8020}$ is associated with a 0.029 times standard deviation reduction on the probability of receiving a higher share of private projects. Nevertheless, using deciles dispersion ratio $\mathrm{P}_{8020}$ might neglect the information of households located in the middle of the distribution. Therefore, in column 2 we use another deciles dispersion ratio $\mathrm{P}_{8050}$, or the ratio of the average 20 percent richest divided by the median's consumption. The inclusion of this inequality measurement also gives a negative and significant effect, although its magnitude is higher and more significant. Finally, we also consider the problem of vulnerability in extreme values and outliers in the distribution. In column 3 to 5 we include inequality measures with axiomatic foundations, namely the Gini index, the general entropy index (GE) and the Atkinson index. Still, the coefficients of inequality measurements remain negative and significant.

Nevertheless, we acknowledge the threat of potential endogeneity issues that may generate biased parameter estimates. The first is the possibility that there is an unobserved heterogeneity that might affect BKM selection process, which would then affect the probability of a BKM member getting elected as well as the project choice simultaneously. We try to limit this problem through our comprehensive set of control variables, as well as

network through the participation in the UPP2, and therefore may cause an endogeneity issue. However, the types of local activists listed in the questionnaire were those whom respondents were unlikely to meet through the UPP2, as the project was specifically designed to be less connected with the governmental structures to guarantee its independency. 
district fixed effects. The second endogeneity threat might arise from the reverse causality issue. However, we argue that this reverse relationship is unlikely as the main independent variable, community inequality, is predetermined before the project takes place.

As for the control variables, we include access to public services to capture the pre-existing public goods available, which were exogenously provided by the government prior to the initiation of UPP2. The variable distance to the nearest central bus station is our proxy for road access. This variable is positive and statistically significant. It implies that greater access to the nearest central bus station is associated with a lower share of private good projects received. We would expect that the better the access to public goods, the higher the allocation that can be spent for private good projects. However, our data analysis suggested the opposite effect, signaling a project mis-targeting. Furthermore, we also include the number of mosques as one of the control variables because Indonesia is the largest Muslim country in the world. Rao (2005) describes the important role of mosques as "symbolic public goods" in collective action, which is vital to generate the common knowledge and build a sense of community. Mosques in Indonesia are often used to host development activities, providing a venue for community meetings, discussions about community's development, and to provide public announcement. In line with this argument, the estimation results show that the higher the number the mosques, the higher the likelihood to receive pro-poor projects.

Of the remaining independent variables, kelurahan mean consumption is strongly positive and significant, which means that the share of private projects is higher in better off kelurahan. One could assume that higher rates of poverty would generate more private projects. Yet, our econometric results show a different pattern. Holding other variables constant, lower mean consumption is associated with fewer private projects, which again flag possible targeting problems of UPP2. Alternatively, it may suggest that in richer communities, there is less competition for these funds, which then allowing the poor to access a greater share. 
Table 1.6 Determinants of receiving private projects as the proportion of the total non-revolving projects

\begin{tabular}{|c|c|c|c|c|c|c|c|c|c|c|}
\hline & \multicolumn{5}{|c|}{ Community inequality } & \multicolumn{5}{|c|}{ Composition of board members in BKM } \\
\hline & (1) & (2) & (3) & (4) & (5) & (6) & (7) & $(8)$ & (9) & $(10)$ \\
\hline Mean of per capita consumption (log) & $\begin{array}{l}0.454^{* * *} \\
(2.816)\end{array}$ & $\begin{array}{l}0.389 * * * \\
(2.738)\end{array}$ & $\begin{array}{l}0.437 * * * \\
(2.942)\end{array}$ & $\begin{array}{l}0.406 * * * \\
(2.692)\end{array}$ & $\begin{array}{l}0.478^{* * *} \\
(3.060)\end{array}$ & $\begin{array}{l}0.497 * * * \\
(2.989)\end{array}$ & $\begin{array}{l}0.419 * * * \\
(2.866)\end{array}$ & $\begin{array}{l}0.485^{* * *} \\
(3.114)\end{array}$ & $\begin{array}{l}0.442 * * * \\
(2.838)\end{array}$ & $\begin{array}{l}0.526 * * * \\
(3.248)\end{array}$ \\
\hline Population (log) & $\begin{array}{l}-0.248 \\
(-1.187)\end{array}$ & $\begin{array}{l}-0.237 \\
(-1.144)\end{array}$ & $\begin{array}{l}-0.225 \\
(-1.087)\end{array}$ & $\begin{array}{l}-0.240 \\
(-1.150)\end{array}$ & $\begin{array}{l}-0.235 \\
(-1.137)\end{array}$ & $\begin{array}{l}-0.210 \\
(-1.060)\end{array}$ & $\begin{array}{l}-0.197 \\
(-1.005)\end{array}$ & $\begin{array}{l}-0.187 \\
(-0.953)\end{array}$ & $\begin{array}{l}-0.200 \\
(-1.016)\end{array}$ & $\begin{array}{l}-0.197 \\
(-1.007)\end{array}$ \\
\hline Distance to central bus station (minutes) & $\begin{array}{l}0.005^{*} \\
(1.886)\end{array}$ & $\begin{array}{l}0.005^{*} \\
(1.878)\end{array}$ & $\begin{array}{l}0.005^{* *} \\
(2.109)\end{array}$ & $\begin{array}{l}0.005^{*} \\
(1.839)\end{array}$ & $\begin{array}{l}0.005^{* *} \\
(2.055)\end{array}$ & $\begin{array}{l}0.005^{*} \\
(1.755)\end{array}$ & $\begin{array}{l}0.005^{*} \\
(1.772)\end{array}$ & $\begin{array}{l}0.005^{*} \\
(1.949)\end{array}$ & $\begin{array}{l}0.005^{*} \\
(1.722)\end{array}$ & $\begin{array}{l}0.005^{*} \\
(1.890)\end{array}$ \\
\hline Number of mosques & $\begin{array}{l}0.016^{* *} \\
(2.138)\end{array}$ & $\begin{array}{l}0.016^{* *} \\
(2.148)\end{array}$ & $\begin{array}{l}0.016^{* *} \\
(2.309)\end{array}$ & $\begin{array}{l}0.016^{* *} \\
(2.169)\end{array}$ & $\begin{array}{l}0.017 * * \\
(2.356)\end{array}$ & $\begin{array}{l}0.015 * \\
(1.795)\end{array}$ & $\begin{array}{l}0.015^{*} \\
(1.828)\end{array}$ & $\begin{array}{l}0.016^{* *} \\
(1.961)\end{array}$ & $\begin{array}{l}0.015 * \\
(1.822)\end{array}$ & $\begin{array}{l}0.016^{* *} \\
(1.994)\end{array}$ \\
\hline $\mathrm{P}_{8020}$ & $\begin{array}{l}-0.029 * * \\
(-2.521)\end{array}$ & & & & & $\begin{array}{l}-0.030 * * * \\
(-2.596)\end{array}$ & & & & \\
\hline $\mathrm{P}_{8050}$ & & $\begin{array}{l}-0.059 * * \\
(-2.334)\end{array}$ & & & & & $\begin{array}{l}-0.059 * * \\
(-2.405)\end{array}$ & & & \\
\hline Gini index & & & $\begin{array}{l}-1.320^{* *} \\
(-2.519)\end{array}$ & & & & & $\begin{array}{l}-1.381^{* * *} \\
(-2.658)\end{array}$ & & \\
\hline GE index & & & & $\begin{array}{l}-0.585^{* *} \\
(-2.550)\end{array}$ & & & & & $\begin{array}{l}-0.589 * * * \\
(-2.611)\end{array}$ & \\
\hline Atkinson index & & & & & $\begin{array}{l}-1.469 * * * \\
(-2.795)\end{array}$ & & & & & $\begin{array}{l}-1.530 \text { *** } \\
(-2.954)\end{array}$ \\
\hline Homogenous and high status & & & & & & $\begin{array}{l}-0.239 \\
(-1.154)\end{array}$ & $\begin{array}{l}-0.217 \\
(-1.036)\end{array}$ & $\begin{array}{l}-0.260 \\
(-1.169)\end{array}$ & $\begin{array}{l}-0.218 \\
(-1.028)\end{array}$ & $\begin{array}{l}-0.256 \\
(-1.175)\end{array}$ \\
\hline Homogenous and low status & & & & & & $\begin{array}{l}0.157^{*} \\
(1.931)\end{array}$ & $\begin{array}{l}0.157^{*} \\
(1.913)\end{array}$ & $\begin{array}{l}0.151^{*} \\
(1.851)\end{array}$ & $\begin{array}{l}0.158^{*} \\
(1.932)\end{array}$ & $\begin{array}{l}0.153^{*} \\
(1.881)\end{array}$ \\
\hline Heterogeneous and high status & & & & & & $\begin{array}{l}0.010 \\
(0.104)\end{array}$ & $\begin{array}{l}0.025 \\
(0.259)\end{array}$ & $\begin{array}{l}-0.006 \\
(-0.066)\end{array}$ & $\begin{array}{l}0.011 \\
(0.111)\end{array}$ & $\begin{array}{l}-0.004 \\
(-0.040)\end{array}$ \\
\hline Number of observations & 153 & 153 & 153 & 153 & 153 & 153 & 153 & 153 & 153 & 153 \\
\hline AIC & 1.25 & 1.25 & 1.25 & 1.25 & 1.25 & 1.29 & 1.29 & 1.29 & 1.29 & 1.29 \\
\hline BIC & -599.25 & -599.24 & -599.25 & -599.22 & -599.27 & -584.33 & -584.32 & -584.34 & -548.30 & -584.37 \\
\hline
\end{tabular}

The dependent variable is the share of the project budget allocated to private non-revolving fund projects per total cost of the non-revolving projects. The results are obtained using a fractional logit method. Tvalues in parentheses. ${ }^{* * *} \mathrm{p}<0.01,{ }^{* *} \mathrm{p}<0.05,{ }^{*} \mathrm{p}<0.1$. Constants are not reported. The estimation also controls for the amount of UPP2 fund received by the community and access to public electricity. Districts fixed effects are included. 


\subsubsection{The composition of BKM members and project selection}

The second objective of this study is to examine whether the bargaining power of the board members in BKM decision-making process, influences the budget allocation towards private good projects. To do this, in Table 1.7 we first estimate the probability of getting elected to BKM by pooling individual data of both BKM and non-BKM members (household samples). The results suggest that BKM members are significantly more educated, have more per capita consumption and more social connectedness. Further controlling for individual characteristics, such as gender, age, and Muslim dummy variable, column 2 in Table 1.7 shows that BKM members are more likely to be older (with non-linear pattern), male, and Muslim.

Table 1.7 Logistic regressions: determinants of community organization membership

\begin{tabular}{lcc}
\hline & $(1)$ & $(2)$ \\
\hline & & \\
Years of schooling & $0.308^{* * *}$ & $0.308^{* * *}$ \\
Per capita consumption (log) & $(14.612)$ & $(14.170)$ \\
& $1.131^{* * *}$ & $1.012^{* * *}$ \\
Social network & $(12.131)$ & $(10.168)$ \\
& $8.173^{* * *}$ & $8.233^{* * *}$ \\
Age & $(17.818)$ & $(17.441)$ \\
& & $0.302^{* *}$ \\
Age squared & & $(8.909)$ \\
& & $-0.003^{* *}$ \\
Female & & $(-7.854)$ \\
& & $-0.647^{* * *}$ \\
Muslim & & $(-5.192)$ \\
& & $0.867^{* * *}$ \\
District fixed effect & Yes & $(3.839)$ \\
Number of observations & 14,335 & Yes \\
Pseudo R2 & 0.37 & 14,331 \\
\hline The dependent variable is the probability that a person is elected as a BKM member. T-values in the parenthesis. *** $<<0.01$, \\
$* *$ p $<0.05, * 0.1$.
\end{tabular}

The results of Table 1.7 suggest that variable years of schooling, per capita consumption and social network, are the prominent factors that determine the bargaining power of BKM members in decision-making process. Based on this, we use these three factors together to construct an elite index using the first principal component. On the basis of the composition of BKM members' elite index, we classify each BKM institution into one of four BKM categories, which indicate the process of bargaining power inside BKM, namely homogeneously high status $\left(\mathrm{Hm}^{h}\right)$, homogeneously low status $\left(\mathrm{Hm}^{l}\right)$, heterogeneously high status $\left(H t^{h}{ }_{i}\right)$, or heterogeneously low status $\left(H t_{i}^{l}\right)$. 
These BKM categories are then included in the model specification as additional dummy variables (Table 1.6 column 6 to 10). For instance, the dummy variable "homogeneously high (low) status" takes the value of 1 if all (none) of the sampled BKM members have elite status and 0 otherwise. While BKM dummy variable "heterogeneously high (low) status" takes the value of 1 if the majority of the sampled BKM members have high (low) status and 0 otherwise.

Comparing columns 1 to 5 and columns 6 to 10 of Table 1.6, it seems that the inclusion of BKM dummy variables does not change the results that inequality variables remain negative and significant. Nevertheless, BKM dummy variable "homogenously low status" is significant, compared to the left-out category: This result suggests that the allocation of private good projects is more likely in kelurahan where all sampled BKM members have no elite status.

Furthermore, we explore the link between the elite status of BKM members with the characteristics of residents and the community where BKM members are living in. Table 1.8 compares the characteristics of BKM members with the general population, and the community characteristics based on four BKM categories.

Table 1.8 Summary characteristics by BKM type

\begin{tabular}{|c|c|c|c|c|}
\hline Community Organization Status & $\begin{array}{c}\mathrm{Hm}^{h}{ }_{i} \\
\text { Homogeneously } \\
\text { high } \\
\end{array}$ & $\begin{array}{c}H t^{h}{ }_{i} \\
\text { Heterogeneously } \\
\text { high } \\
\end{array}$ & $\begin{array}{c}H t_{i}^{l} \\
\text { Heterogeneously } \\
\text { low } \\
\end{array}$ & $\begin{array}{c}\mathrm{Hm}_{i}^{l} \\
\text { Homogeneously } \\
\text { low } \\
\end{array}$ \\
\hline \multicolumn{5}{|l|}{ BKM members characteristics } \\
\hline Consumption per capita (rupiah) & 806,559 & 457,460 & 412,892 & 288,238 \\
\hline Years of education & 15.6 & 14.79 & 13.44 & 12.5 \\
\hline Social networks & 0.94 & 0.93 & 0.93 & 0.91 \\
\hline \multicolumn{5}{|l|}{ General population characteristics } \\
\hline Consumption per capita (rupiah) & 214,990 & 240,524 & 219,230 & 204,581 \\
\hline Years of education & 10.1 & 9.7 & 9.2 & 9.2 \\
\hline Social networks & 0.64 & 0.67 & 0.64 & 0.60 \\
\hline \multicolumn{5}{|l|}{ Community characteristics } \\
\hline Population & 4,775 & 6,018 & 5,709 & 5,923 \\
\hline Access to public electricity & 0.99 & 0.98 & 0.98 & 0.93 \\
\hline Distance to central bus station (minutes) & 9.00 & 12.89 & 15.79 & 15.96 \\
\hline Number of mosques & 6 & 6 & 7 & 6 \\
\hline Total UPP2 fund (million rupiah) & 230 & 256 & 248 & 272 \\
\hline Gini index & 0.30 & 0.34 & 0.34 & 0.32 \\
\hline GE index & 0.19 & 0.22 & 0.20 & 0.18 \\
\hline Atkinson index & 0.14 & 0.17 & 0.17 & 0.15 \\
\hline P8020 & 4.45 & 6.29 & 5.68 & 5.15 \\
\hline P8050 - 2 & 2.54 & 3.19 & 2.74 & 2.49 \\
\hline Number of BKM & 5 & 36 & 63 & 50 \\
\hline
\end{tabular}


Based on Table 1.8, it interestingly appears that the board members who have position in "homogeneously low" BKM have on average the lowest per capita consumption, the lowest years of education and the lowest social networks. ${ }^{16}$ However, when focusing on the characteristics of the residents who live in the same kelurahan as the "homogeneously low" $\mathrm{BKM}$, it appears that the local residents have on average the lowest consumption, lowest years of education and lowest social network. It is also shown that BKM members sitting in "homogeneously low" BKM are living in the poorest kelurahan with the worst access to electricity and transportation, signaling that in kelurahan where BKM members homogeneously have no elite status, the boards still prioritize the private good projects even though the pre-existence of public goods is low. These findings imply that when BKM members share similar characteristics with the poor, they have within-community affinity, and thus engage in altruistic behavior by giving higher preference to private good projects.

\subsubsection{Robustness checks}

For robustness checks, we examine how communities favor non-revolving and revolving mechanism projects. As mentioned in the earlier part of this paper, the revolving fund projects are targeted to the non-poor, yet expected to provide indirect multiplier effects to the poor. Thus, for robustness checks we alternatively define the dependent variable as the ratio of housing programs, social programs, and economic programs that were given under nonrevolving mechanism as a share of total project costs (revolving plus non-revolving projects). Table 1.9 repeats the key regressions of Table 1.6 and show a similar pattern although with smaller coefficient magnitude and weaker significances.

\footnotetext{
${ }^{16}$ This clearly makes sense since the computation of elite index is based on these three variables.
} 
Table 1.9 Robustness check using alternative dependent variable

\begin{tabular}{|c|c|c|c|c|c|c|c|c|c|c|}
\hline & \multicolumn{5}{|c|}{ Community inequality } & \multicolumn{5}{|c|}{ Composition of board members in BKM } \\
\hline & $(1)$ & $(2)$ & (3) & (4) & (5) & (6) & $(7)$ & (8) & (9) & $(10)$ \\
\hline Mean of per capita consumption (log) & $\begin{array}{l}0.373^{* * *} \\
(2.641)\end{array}$ & $\begin{array}{l}0.324^{* *} \\
(2.539)\end{array}$ & $\begin{array}{l}0.305^{* *} \\
(2.286)\end{array}$ & $\begin{array}{l}0.323^{* *} \\
(2.418)\end{array}$ & $\begin{array}{l}0.342^{* *} \\
(2.460)\end{array}$ & $\begin{array}{l}0.404 * * * \\
(2.756)\end{array}$ & $\begin{array}{l}0.346 * * * \\
(2.584)\end{array}$ & $\begin{array}{l}0.339 * * \\
(2.396)\end{array}$ & $\begin{array}{l}0.350^{* *} \\
(2.497)\end{array}$ & $\begin{array}{l}0.377^{* * *} \\
(2.588)\end{array}$ \\
\hline Population (log) & $\begin{array}{l}-0.253^{*} \\
(-1.660)\end{array}$ & $\begin{array}{l}-0.244 \\
(-1.608)\end{array}$ & $\begin{array}{l}-0.235 \\
(-1.549)\end{array}$ & $\begin{array}{l}-0.245 \\
(-1.605)\end{array}$ & $\begin{array}{l}-0.241 \\
(-1.595)\end{array}$ & $\begin{array}{l}-0.222 \\
(-1.534)\end{array}$ & $\begin{array}{l}-0.212 \\
(-1.470)\end{array}$ & $\begin{array}{l}-0.204 \\
(-1.420)\end{array}$ & $\begin{array}{l}-0.213 \\
(-1.474)\end{array}$ & $\begin{array}{l}-0.211 \\
(-1.470)\end{array}$ \\
\hline Distance to central bus station (minutes) & $\begin{array}{l}0.006 * * * \\
(2.737)\end{array}$ & $\begin{array}{l}0.006^{* * *} \\
(2.730)\end{array}$ & $\begin{array}{l}0.006^{* * *} \\
(2.705)\end{array}$ & $\begin{array}{l}0.005^{* * *} \\
(2.681)\end{array}$ & $\begin{array}{l}0.006 * * * \\
(2.725)\end{array}$ & $\begin{array}{l}0.005^{* *} \\
(2.532)\end{array}$ & $\begin{array}{l}0.006^{* *} \\
(2.558)\end{array}$ & $\begin{array}{l}0.006^{* *} \\
(2.525)\end{array}$ & $\begin{array}{l}0.005^{* *} \\
(2.498)\end{array}$ & $\begin{array}{l}0.006^{* *} \\
(2.523)\end{array}$ \\
\hline Number of mosques & $\begin{array}{l}0.014 * * \\
(1.992)\end{array}$ & $\begin{array}{l}0.014 * * \\
(1.996)\end{array}$ & $\begin{array}{l}0.013^{* *} \\
(2.006)\end{array}$ & $\begin{array}{l}0.013 * * \\
(1.988)\end{array}$ & $\begin{array}{l}0.014^{* *} \\
(2.062)\end{array}$ & $\begin{array}{l}0.013^{*} \\
(1.699)\end{array}$ & $\begin{array}{l}0.013^{*} \\
(1.721)\end{array}$ & $\begin{array}{l}0.012^{*} \\
(1.709)\end{array}$ & $\begin{array}{l}0.013^{*} \\
(1.692)\end{array}$ & $\begin{array}{l}0.013^{*} \\
(1.759)\end{array}$ \\
\hline $\mathrm{P}_{8020}$ & $\begin{array}{l}-0.020^{* *} \\
(-2.389)\end{array}$ & & & & & $\begin{array}{l}-0.020^{* *} \\
(-2.504)\end{array}$ & & & & \\
\hline $\mathrm{P}_{8050}$ & & $\begin{array}{l}-0.040 * * \\
(-2.408)\end{array}$ & & & & & $\begin{array}{l}-0.039 * * \\
(-2.479)\end{array}$ & & & \\
\hline Gini index & & & $\begin{array}{l}-0.605 \\
(-1.360)\end{array}$ & & & & & $\begin{array}{l}-0.628 \\
(-1.432)\end{array}$ & & \\
\hline GE index & & & & $\begin{array}{l}-0.359 * * \\
(-2.104)\end{array}$ & & & & & $\begin{array}{l}-0.356 * * \\
(-2.166)\end{array}$ & \\
\hline Atkinson index & & & & & $\begin{array}{l}-0.769 * \\
(-1.702)\end{array}$ & & & & & $\begin{array}{l}-0.794 * \\
(-1.806)\end{array}$ \\
\hline Homogenous and high status & & & & & & $\begin{array}{l}-0.142 \\
(-0.994)\end{array}$ & $\begin{array}{l}-0.126 \\
(-0.881)\end{array}$ & $\begin{array}{l}-0.144 \\
(-0.944)\end{array}$ & $\begin{array}{l}-0.126 \\
(-0.865)\end{array}$ & $\begin{array}{l}-0.146 \\
(-0.961)\end{array}$ \\
\hline Homogenous and low status & & & & & & $\begin{array}{l}0.122 * \\
(1.825)\end{array}$ & $\begin{array}{l}0.122 * \\
(1.816)\end{array}$ & $\begin{array}{l}0.119 * \\
(1.774)\end{array}$ & $\begin{array}{l}0.122 * \\
(1.827)\end{array}$ & $\begin{array}{l}0.119 * \\
(1.781)\end{array}$ \\
\hline Heterogeneous and high status & & & & & & $\begin{array}{l}-0.002 \\
(-0.029)\end{array}$ & $\begin{array}{l}0.008 \\
(0.100)\end{array}$ & $\begin{array}{l}-0.013 \\
(-0.156)\end{array}$ & $\begin{array}{l}-0.002 \\
(-0.029)\end{array}$ & $\begin{array}{l}-0.012 \\
(-0.147)\end{array}$ \\
\hline Number of observations & 153 & 153 & 153 & 153 & 153 & 153 & 153 & 153 & 153 & 153 \\
\hline AIC & 1.113 & 1.113 & 1.114 & 1.114 & 1.114 & 1.152 & 1.152 & 1.152 & 1.152 & 1.152 \\
\hline BIC & -601.54 & -601.54 & -601.51 & -601.52 & -601.52 & -586.52 & -586.52 & -586.49 & -586.50 & -586.50 \\
\hline
\end{tabular}

The dependent variable is the share of UPP2 budget allocated to private non-revolving fund projects per total project cost. The results are obtained using the fractional logit. $T$-Values in parentheses. $* * * \mathrm{p}<0.01$, $* *$ $\mathrm{p}<0.05$, * $\mathrm{p}<0.1$. Constants are not reported. The estimation also controls for the amount of UPP2 fund received by community; interaction between population and the amount of UPP2 fund received, and access to public electricity. District fixed effects are included. 


\subsection{Conclusions}

Currently, community-driven development approach has been used in delivering many poverty programs based on the presumption that it may foster sustained poverty reduction through social inclusion. However, recent literature has shown that such an approach may increase the risk of elite capture, particularly in more unequal communities where the gap between non-poor and poor is more severe.

In this study, we empirically examine the existence of elite capture within the Urban Poverty Project 2, a nationwide CDD program implemented in Indonesia. Classifying types of poverty programs into private good projects and public good projects which could be translated into pro-poor and less pro-poor projects, our results suggest that the incidence of elite capture is more likely to occur in unequal communities. Furthermore, the econometric analysis demonstrates that the composition of representatives in the local body matter for the allocation of pro-poor projects. Constructing elite status index based on the combination of level of education, consumption, and social connectedness, we find that only when local representatives closely share characteristics with the poor, does altruistic behavior exist and thus project decision favor the poor.

These findings are relevant to the hundreds of CDD programs currently in operation in developing countries. It does not necessarily imply that participatory approach is not working. Instead, we suggest policy makers to put more attention on the resilience of the local power structure, the decision-making process, and the consequent need for pro-poor initiatives, in order to ensure an accurate poverty targeting strategy. 


\title{
2 Do bribes get the officials off your back?
}

\begin{abstract}
This paper tests the "grease the wheels" hypothesis of corruption, by examining the impact of bribes on the effectiveness of public service delivery. Using data from 470 firms in Indonesia, the econometric analysis suggests a view inconsistent with the hypothesis: firms that pay higher bribes experiencing a higher share of managerial time spent with public officials, not less. In the context of the competitive bribery with asymmetric information, where the average amount of bribes needed to reduce bureaucracy is unknown for firms, this paper still finds no evidence supporting the "grease the wheels” hypothesis.
\end{abstract}




\subsection{Introduction}

Corruption occurs when public officials misuse their power for private gain. This abuse of power happens when officials sell government property for their own benefit, give kickbacks in public procurement, accept bribes, embezzle government funds, or participate in patronage or nepotism. Although the impact of corruption on development may vary, most economists view it as a major obstacle to development (Mauro, 1995; Tanzi and Davoodi 2002; Meon and Sekkat, 2005). Macro studies have highlighted that corruption weakens institutions and distorts competition, and thereby reduces private investment and lowers growth. Pioneering the quantitative research on corruption, Mauro (1995) finds that a reduction of the corruption index by one standard deviation increases the growth rate by about 0.8 points.

The view that corruption is detrimental to growth, however, is not shared by all economists, as some argue that corruption can actually be efficiency enhancing. This view is known as the "grease the wheels" hypothesis. Motivated by Leff (1964) and elaborated by Leys (1965) and Huntington (1968), the hypothesis proposes that corruption can be beneficial in countries with poor governance and cumbersome bureaucracy. Huntington (1968) states: “In terms of economic growth, the only thing worse than a society with a rigid, over-centralized, dishonest bureaucracy is one with a rigid, over-centralized, honest bureaucracy." The hypothesis implies that if an inefficient bureaucracy is a barrier to economic activity, "grease” money may speed up the rigid administration. Lui (1985) offers an illustration in the context of customer lines and demonstrates that when bribes are regarded as legal payment, they can significantly reduce the time spent standing in line.

However, the "grease the wheels" idea may not work, given the complexity of a bribery transaction. It is illegal and hidden, and therefore it is uncertain whether the corrupt official will credibly commit to an agreement made during the transaction. A corrupt official may deliberately impose administrative delays in order to attract further bribes (Myrdal, 1968; Andvig, 1991). A number of empirical studies even reveal a "sand the wheels" effect of corruption. For instance, firm-level analyses find a positive relationship between amounts of money spent on bribes and the bureaucratic burden, proxied by the percentage of managerial time spent with officials to deal with regulations (Kaufmann and Wei, 1999; Henderson and Kuncoro, 2004; Fisman and Gatti, 2006). They show that firms that pay more money in 
bribes spend more, not less, managerial time with public officials. These empirical contributions thus have provided an important alternative insight to the "grease the wheels" hypothesis.

Nevertheless, these studies do not take into account the potential reverse causality relationship that may exist between the two key variables: amount spent on bribes and time spent with officials to deal with bureaucracy. Ignoring this issue may result in inconsistent parameters and therefore misleading conclusions. In this study, I use two survey rounds of MICI data (Monitoring Investment Climate Indicators), which contain information on the experiences of 470 firms in dealing with bureaucrats in Indonesia. Given the advantage of the panel data structure, the lagged value of bribes is used to instrument the current bribes. Since the chosen instrumental variable is predetermined, applying the 2SLS approach may give a consistent parameter. Taking this into account, the results of this study further confirm the positive relationship between bribery and managerial time spent with officials. In this respect, these results complement previous analyses of Kaufmann and Wei (1999), Henderson and Kuncoro (2004), and Fisman and Gatti (2006). The second contribution of this paper with respect to the literature is the assessment of the "grease the wheels" hypothesis in the context of competitive bribery and imperfect information. To my knowledge, this paper represents the first attempt to empirically test the "grease the wheels" hypothesis using this framework.

In a competitive bribery setting, firms need to compete to obtain the favors from the government, such as the issuance of scarce government licenses. In this situation, a bribemaximizing official may act as a monopolist, limiting the licenses, but never reveals the selection criteria to obtain the license. Similar to a sealed auction, each firm thus will offer a bribe amount based on their beliefs regarding how much their competitors have paid, making the average amount of bribes needed to get the government goods unknown. On the other hand, a corrupt official, who has full information regarding the bribes paid by each firm as well as firm characteristics, can estimate the expected bribe value of each firm. This paper shows that when a firm pays a higher amount of bribes than the average bribe, officials might identify the specific firm as a "weak" firm that is less reluctant to pay large bribes, and therefore shall face further bureaucratic delays.

To support these conclusions, the remainder of this paper is organized as follows: Section 2 presents a selective overview of related corruption literature and the testable hypotheses used 
in this study. Section 3 describes the estimation method. Section 4 presents data and some descriptive analysis. Section 5 presents the results and discussion, and section 6 concludes the study.

\subsection{Literature review and hypothesis}

In a seminal paper on corruption, Shleifer and Vishny (1993) present a model in which the government is the sole producer of a homogeneous government good and an official acts as the supplier of this good. As a supplier, the official has the opportunity to restrict the slots of the government good, by creating a long delay or imposing further requirements. In this case, the "grease the wheels" hypothesis suggests that bribes can be considered as speed money that may eliminate such bureaucratic delays. Lui (1985) formalizes this mechanism by setting a single-line queue model in the context of customer lines. He shows that when bribes are considered as legal payments, faster service can be awarded by the organizers on the basis of the bribe's size, which reflects the customer's time valuation and therefore the customer's willingness to pay.

Although "the grease the wheels" hypothesis may sound appealing, one strand of literature argues that larger bribes do not necessarily circumvent bureaucracy. In the case of speed money, Myrdal (1968) argues that the secrecy surrounding bribery scheme results in a more complex bribery system, where corrupt officials may deliberately cause administrative delays in order to attract more bribes. Andvig (1991) further points out that in the case of the customer queue, organizers may evaluate the line to test the participants' willingness to pay, and thereby increase the average waiting time. In most cases, standing in line only happens when there is a long processing time.

A number of empirical studies also support the alternative view of "the grease the wheels" hypothesis. Kaufmann and Wei (1999) develop a model in which effective bureaucratic harassment (proxied by the amount of time spent with bureaucracy) is endogenous, as officials have the ability to customize red tape. Their model predicts that firms that pay more bribes not only face more imposed regulations, but also have to deal with more effective bureaucratic harassment. Using firm-level data from three global surveys, their results show that firms that pay more bribes experience more wasted time with officials. Henderson and 
Kuncoro (2004) adapt the Kaufmann and Wei (1999) model and use firm-level data from 1,808 firms to estimate the key aspects of corruption, i.e. bribes, time spent with officials, and different forms of regulation. They find that both bribes and time rise strongly with different forms of bureaucratic harassment. Although the authors struggle with endogeneity issues, they show a significant positive relationship between bribes and the share of managerial time spent with officials, arguing that officials tend to nurture good relationships with their best “customers". Fisman and Gatti (2006) use firm-level data across countries and further confirm the positive correlation between bribery and the amount of time spent with bureaucracy.

To date, the available firm-level empirical studies show no support for the "grease the wheels" hypothesis. The data suggest that larger bribes may increase the managerial time spent with government officials to expedite business, because public officials may customize the rules and regulations to further collect the firm's surplus. Given the explanation, this study hypothesizes that: higher spending on bribes is associated with increased management time spent with officials.

Furthermore, I examine the "grease the wheels" hypothesis in the context of competitive bribery under asymmetric information. In competitive bribery, all firms need to bribe in order to gain the attention of government officials; those who refuse to compete will be driven out from the market, leaving the most efficient ones to be milked (Bliss and Di Tella, 1997). In situations where all firms need to pay bribes, and there is only one official that has the power to grant or withhold a government good, the official has the position of a monopolist. As a result, a corrupt official has an incentive to limit the slots of the government good and thus evaluate each firm's willingness to pay bribes in order to maximize bribe revenues. The "grease the wheels" hypothesis would suggest that those who are willing and able to pay higher bribes will have a higher priority in getting the slots.

In the context of perfect information, the amount of bribes paid by every firm represents its true value in terms of how much red tape can be reduced by it. However, under asymmetric information, a corrupt official never reveals the reward mechanism, making the average bribe amount needed to reduce the bureaucracy unknown. Additionally, the firms do not know their competitors' bribing capacities. As suggested by the auction theory, each 
participant independently estimates the value of bribes required to reduce the bureaucracy, based on their beliefs about how much their competitors have paid. ${ }^{17}$

Nevertheless, even though the firms do not know the amounts of bribes offered by their competitors, the official who collects and interacts with each firm has all the information on bribe distribution as well as firm characteristics. This information allows them to learn and estimate the average bribe value, given firm characteristics relative to the other firms in the industry (conditional average). Furthermore, the public official may screen firms based on the difference between the size of bribes paid and the average bribe. The literature indicates that public officials may observe firm characteristics and use this information to decide to which firm to grant the government good. Guriev (2004) presents a model in which officials use the information produced through red tape to classify types of firm, then sort out those firms that do not deserve the government goods. Svensson (2003) illustrates that the corrupt official may assess firms according to their ability to pay, which may be reflected in their profit margins. In the context of bribes paid by truck drivers at different check points in Aceh, Olken and Barron (2009) show that officials use different pricing schemes to extract bribes according to driver and truck characteristics, such as the driver's monthly salary, truck age, and tons overweight.

Allocation efficiency would suggest that the firms that pay bribes higher than the average should be able to obtain the government goods ahead of the others. However, firms that pay higher than average bribes might also signal that they are less reluctant to pay high bribes. These firms may be those in need of government goods, or those trying to collude with officials (e.g. to hide illegal activities, etc.). ${ }^{18}$ A corrupt official might identify these firms as the "weak" ones and can be more aggressive in approaching them. As a result, a corrupt official further delays the bureaucracy for these firms, which may take the form of informing

\footnotetext{
17 Corruption literature mostly discusses the isomorphism between competitive bribery and competitive bidding, as proposed by Beck and Maher (1986). In competitive bidding for government purchasing, the contract is allocated to the firm submitting the predetermined lowest price (highest bribe), which has been set prior to the auction. As the most efficient participant who offers the highest bribe always wins, allocation efficiency is always maintained. However, inefficiency may result if the official is influenced by considerations other than just the bribe's size, such as favoritism (Bardhan, 1997; Clark and Riis, 2000).

${ }^{18}$ There is anecdotal evidence in Indonesia that public officials from lower ranks tend to collude with firms that hide illegal activities by allowing exports without permits, overlooking tax evasion, etc. Smith et al. (2003) confidentially interviewed timber industry actors in Indonesia. They show that bribery exacerbates illegal logging, making it unlikely that firms will be controlled or punished.
} 
other corrupt officials about the "catch" so that further bureaucracy can be imposed. ${ }^{19}$ This leads to the second hypothesis of this paper: firms that pay higher than average bribes will spend more time dealing with government officials.

\subsection{Empirical strategy}

This study examines how the share of managerial time spent with officials changes in response to changes in bribes value. The following panel model is estimated:

$$
\text { Time }_{i t}=\alpha_{1}+\alpha_{2} \text { Bribes }_{i t}+\alpha_{3} Z_{i t}+u_{i}+\varepsilon_{i t}
$$

The subscripts denote firm $i$ in survey period $t$. Dependent variable Time is the percentage of managerial time spent with government officials to expedite bureaucracy. Time is high when bureaucrats decide to restrict the supply of government goods, i.e. delaying license issuance, imposing many requirements, prolonging negotiations with firms regarding rules and regulations, etc. In the survey, the following question is given to the respondents: On average, what percent of total company management time was spent with government officials as regulators (law makers, not governments as clients) to expedite business over the last six months? The respondents were provided with six time interval options: $(1)<5$ percent, (2) 5 percent-15 percent, (3) 15 percent-25 percent, (4) 25 percent-50 percent, (5) 50 percent-75 percent and (6) >75 percent. For the empirical analysis, the answer is recorded as 2.5 percent for (1), the midpoint values for (2) to (5), and 87.5 percent for (6).

In equation (2.1), the variable Bribes is the bribe payments as a percentage of total production cost. Here, $\alpha_{2}$ is the parameter of interest, where the efficient grease hypothesis would suggest a negative sign of $\alpha_{2}$ : firms paying higher bribes will be granted less time in dealing with bureaucrats. In the first survey round, variable Bribes is captured by asking: As a percentage of total company production costs in 2004, how much "additional cost" was

\footnotetext{
${ }^{19}$ Hunt and Laszlo (2005) shows that the richer the official's clients, the more frequent and the higher the bribes should be, while Hunt (2005) shows empirically that bribery incidence is higher at institutions with bribe-prone clients.
} 
spent on government bureaucracy to smooth business affairs?

percent of company production costs. $^{20}$

Furthermore, $Z$ is a vector of control variables that comprises firm-level characteristics such as firm size, age, and other firm-level variables. Firm size is measured as the number of employees. The correlation matrix (shown later in this paper) suggests that the correlation between time spent with officials and firm size is non-linear. Therefore, the squared value of the number of employees is included. The specification also controls for the length of firm establishment (age). The firm's experience with public officials may generate a better understanding of government regulations and officials' behavior. Furthermore, older firms may have fulfilled the basic regulation requirements, e.g. business license, building certificate, etc., and may only need to deal with the validity maintenance, which will clearly influence the amount of time spent with public officials.

The rest of the firm-level variables consist of dummy variables describing whether the firm is multinational, has government shareholdings, or has an export-import orientation. Multinational companies (foreign ownership) may be more vulnerable to bureaucratic predation. They are not only more visible to officials, but also need to fulfill more regulations and receive more supervision. In Indonesia, foreign ownership typically cooperates with local partners to discourage such harassment (Kuncoro, 2006). Multinationals are included in the estimation as a dummy variable, taking the value of 1 for a firm with foreign investments and 0 otherwise. Moreover, the model also controls for firms with government shareholdings. The correlation matrix suggests that firms with a government share spend less time on bureaucracy, although the correlation is not significant. This variable is included as a dummy variable, taking the value of 1 if a firm has government ownership and 0 otherwise. The last control variable is whether a firm has an export or import orientation. Firms in this category are manufacturer-exporter firms that usually also import their inputs through customs. As the Indonesian customs clearance efficiency index is historically low, the category of export-import firms is needed to capture the additional time spent clearing goods going through customs. Firms that fall into the export-import category are recorded as 1 and as 0 otherwise. Finally, the model includes sector and region fixed

\footnotetext{
${ }^{20}$ In the second round, the year 2004 is changed to 2005. Given that the survey should capture information over the last 6 months, enumerators understood that firms should give information exactly 6 months prior to the interview taking place.
} 
effects to control for further unobservable characteristics. Given the structure of the data, the panel model is used to estimate equation (2.1).

Still, equation (2.1) may suffer from reverse causality that it may be the case that the amount of time spent with bureaucrats influences the amounts of bribes paid by firms. In order to deal with this issue, variable current bribe $\left(\right.$ Bribes $\left._{t}\right)$ is instrumented using the bribe value in the previous period $\left(\right.$ Bribes $\left._{t-1}\right)$. Given that Bribes $_{t-1}$ is pre-determined, it will not correlate with the dependent variable and can be considered as a convincing instrument. Thus, estimating equation (2.1) with 2SLS may give a consistent parameter.

\subsubsection{Competitive bribery with asymmetric information}

In the context of the competitive bribery with asymmetric information, this study examines whether firms that pay bribes larger than the firm-specific average bribes will influence the amount of time spent with public officials. Equation (2.1) is re-formulated as follows:

$$
\text { Time }_{i t}=\beta_{1}+\beta_{2}(\text { Bribes }- \text { Average Bribes })_{i t}+\beta_{3} Z_{i t}+u_{i}+\varepsilon_{i t}
$$

Although the amount of bribes offered by competitors are unknown to firms, public officials do know the bribe distributions as well as the observed firm characteristics relative to bribe payments and characteristics of other firms in the industry. Thus, corrupt officials can estimate firm-specific average bribes using the following equation:

$$
\text { Bribes }_{i t}=\theta_{1}+\theta_{2} Z_{i t}+\varepsilon_{i t}
$$

Estimating equation (2.3) will give the firm-specific average bribe or the expected bribe (Brlbes). Thus, the predicted error term $\left(\hat{\varepsilon}_{i t}\right)$ captures the difference between the bribes paid by firms and the firm-specific average bribe: $\widehat{\varepsilon_{l t}}=$ Bribes $_{i t}-\widehat{B r l b e}_{l t}$. Applying this to equation (2.2), the empirical model reads:

$$
\text { Time }_{i t}=\beta_{1}+\beta_{2} \widehat{\varepsilon_{l t}}+\beta_{3} Z_{i t}+u_{i}+\varepsilon_{i t}
$$


The "grease the wheels" hypothesis would suggest a negative sign of $\beta_{2}$, implying that the higher the amount of bribes paid compared to the firm-specific average bribes, the lower the amount of managerial time spent with public officials.

\subsection{Data}

In order to examine the effect of bribe payments on the time spent with officials, this study uses firm-level data from the unpublished Monitoring Investment Climate Indicator (MICI). The survey was initiated by the World Bank and carried out by the University of Indonesia, aiming to regularly monitor the business climate in Indonesia. To do this, the survey has been conducted every 6 months since 2005. However, this study only uses the first two rounds that are available.

The first survey round was conducted between February and May in 2005 while the second round took place between late November 2005 and mid-March 2006. The survey collects information regarding firms' experience in interacting with the public office and bureaucrats. Out of the 600 firms that were visited in the first round, 470 of them were re-interviewed in the second round. Additionally, 57 firms were added in the second round as a refresher sample.

Figure 2.1 Sample distribution by location, size, and manufacturing sector

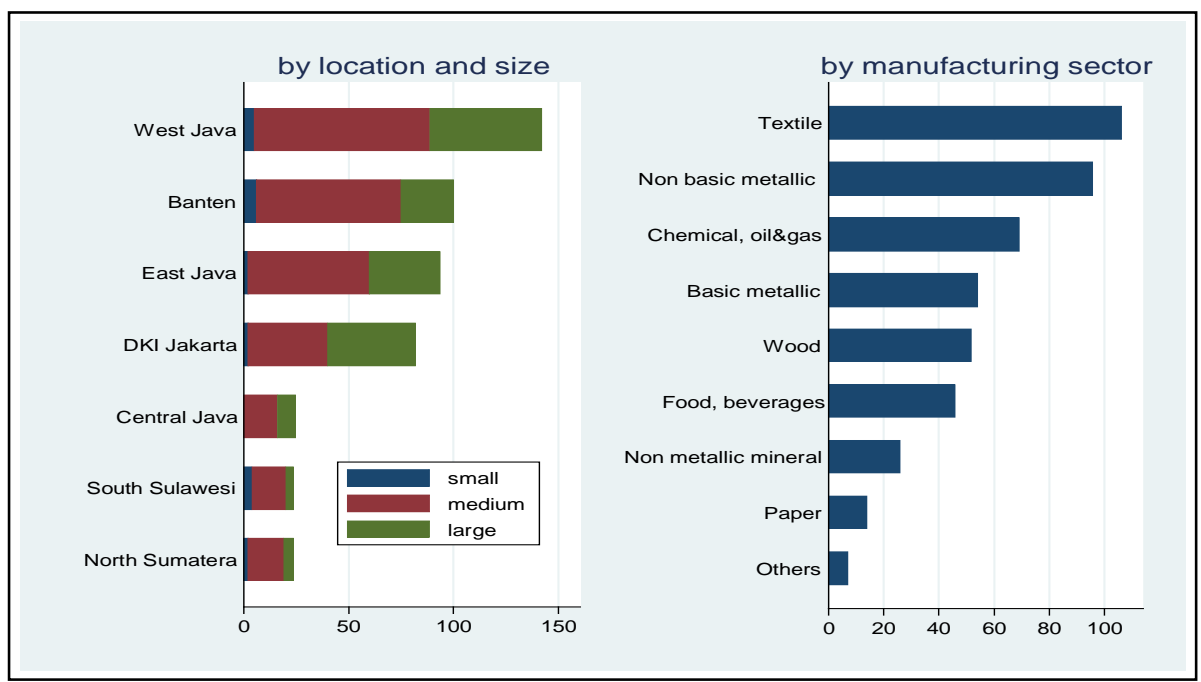

Note: Small firms have less than 100 workers, medium firms between 100-500 workers, and large firms more than 500 workers. 
The survey sampling frame is based on the Manufacturing Firm Directory 2003, published by the BPS. After selecting seven large cities on the basis of an industry agglomeration, proportional random stratification is performed at the regional level where the city is located. Firms with less than 100 workers were excluded from the sample as small firms have a different set of regulations. ${ }^{21}$ Moreover, firms in the agricultural and services sectors were also excluded, as the regulation constraints in the agricultural sector were relatively minor, and there is no reliable data for the services sector. Figure 2.1 shows the sample distribution of firms based on location, size and sectors.

It should be noted that corruption data are typically difficult to obtain due to the sensitivity of the information provided by the respondent. Therefore, the MICI survey employed several data collection strategies to mitigate low responses. First, the survey only interviewed managers who have at least a managerial position, as they are the ones who usually deal with bureaucrats. Second, the survey was carried out by a known independent academic institution, the University of Indonesia. This strategy is important in convincing the managers of research independence and data confidentiality. Furthermore, the interviewers brought with them a letter from the Indonesian Coordinating Ministry of Economic Affairs that guaranteed data confidentiality on paper. This letter, showing that the central government was involved in the survey, did not make firms more reluctant to provide the information. On the contrary, direct interviews revealed that firms are heavily fatigued with the harassments of public officials, and thus agreed that the survey is a way to report what happens on the ground. As the third strategy, the questions in the survey were indirectly phrased in order to avoid implying that the respondent was the one who committed a crime. ${ }^{22}$ For example, on the question of bribe payments, the survey asked: Please give your answer on the statement below? "Companies like yours must pay "additional cost" to government institution to finish business affairs.” As a result, firms were less hesitant to reveal their experiences with bribery. Figure 2.2 illustrates the answer to the above question. Most firms admitted that they often paid bribes to public officials, and this usually took place either in a public office or during the visits performed by officials.

\footnotetext{
${ }^{21}$ Although the BPS Manufacturing Firms Directory 2003 only contains firms with at least 100 employees, the final sample list still contains firms with less than 100 workers, because some firms had made a labor adjustment prior to the survey.

${ }^{22}$ A similar approach was also used in the 1998 Ugandan enterprise survey (Svensson, 2003).
} 

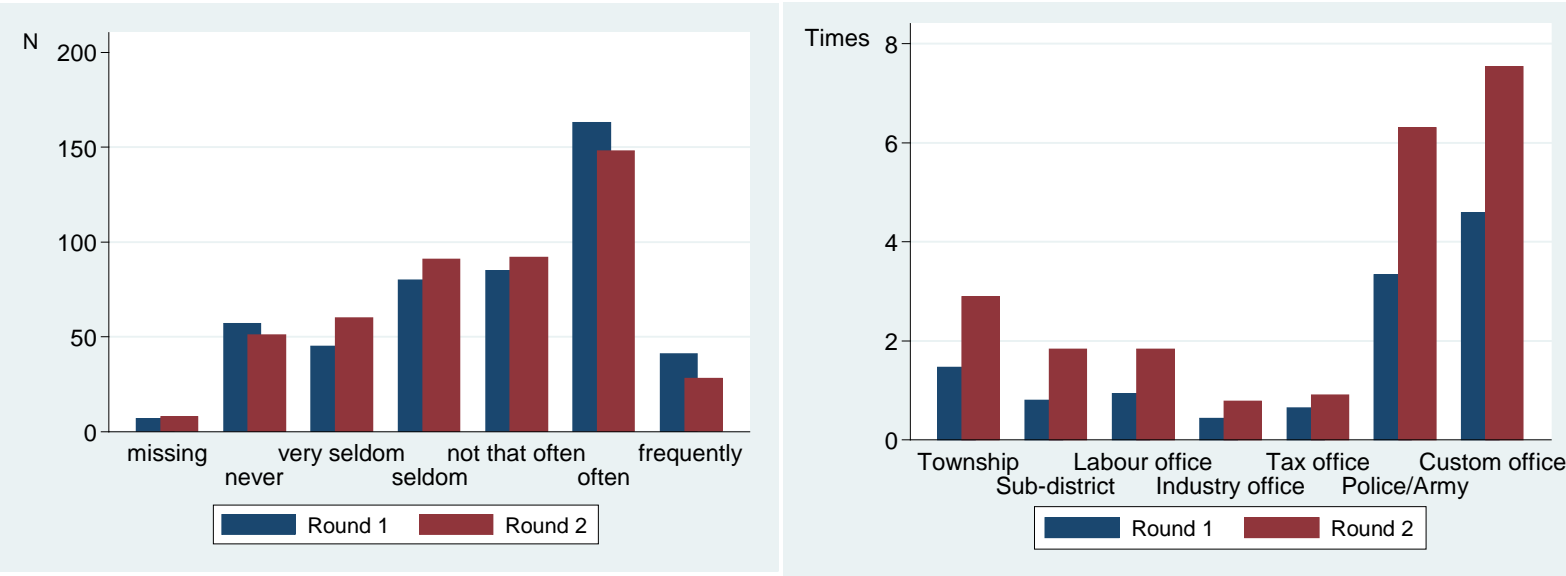

Source: Processed from MICI data 2005-2006.

Figure 2.3 presents a comparison of the average public officials' visits from various public offices. Typically, the purpose of a public official's visit is to check the validity of documents, labor and equipment conditions, standard operations, etc. Figure 2.3 shows that there is a general increasing trend in terms of frequency of visits from the first to the second survey round. It is also reported that the most frequent visits are from the customs office, followed by police/army institutions. Managers stated that the visits from the police / army were conducted to "ensure" their commitment to protecting the firm from any potential security threats.

Figure 2.4 Bribe payments and time spent with officials in two periods
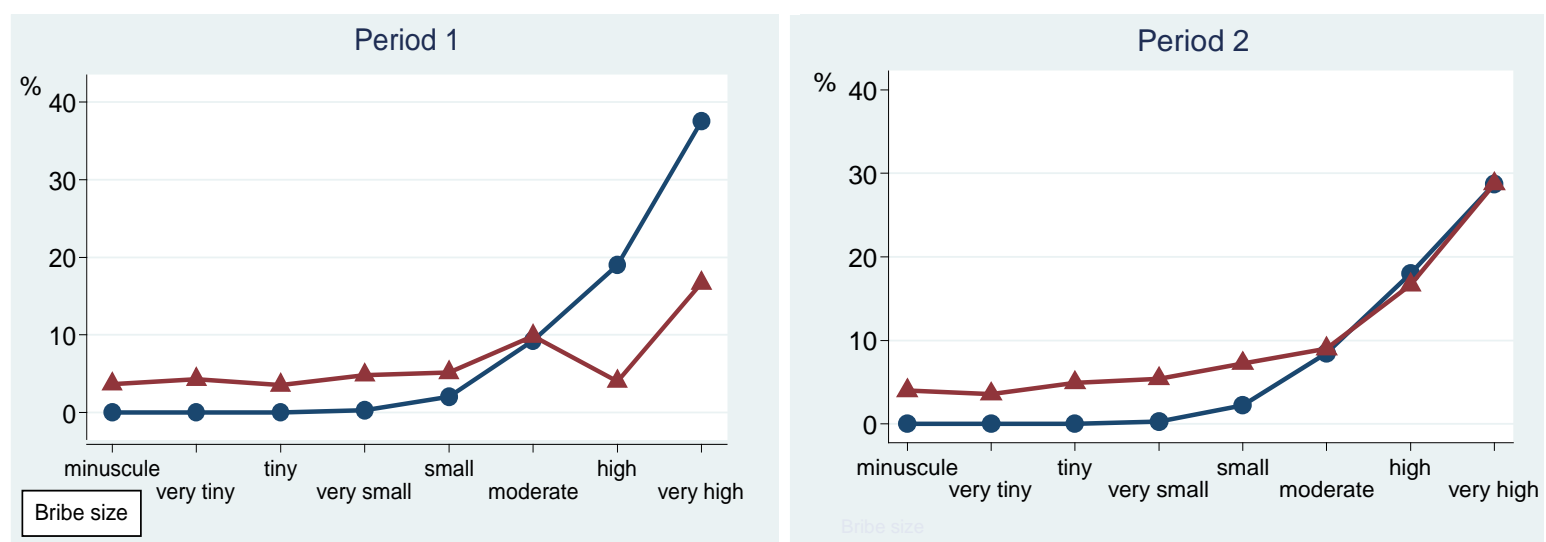

$\longrightarrow$ (mean) share of bribe per total production cost

Notes: The bribe group is based on the bribe payments in period 1 . Minuscule means the bribe ratio is between 0 and 0.0 .000001 percent; very tiny $=0.000009-0.0045$ percent; tiny $=0.005-0.04$ percent; very small=0.05-0.8 percent, small=0.9-5 percent; moderate=6-10 percent; high=12.5-25 percent and very high=27.5-50 percent 
In Figure 2.4, the relationship between bribes and the amount of time spent with public officials is presented. On the horizontal axis, firms are classified into one of the eight bribe groups based on the firm's bribes value, from tiny to very high bribe payments. Each data point in the figure refers to the mean of the bribes and time spent with officials for every bribe group. As both variables are measured as percentages, the vertical axis is measured in percentages. The figure shows a positive relationship between the percentage of bribes paid and the percentage of managerial time spent with officials: the higher the bribes paid, the higher the share of managerial time spent with officials. Although increasing the bribes payment from "moderate" to "high" reduce the time spent with officials in the first round, this correlation did not hold in the second survey round.

\subsection{Estimation results}

Table 2.1 presents the summary statistics. ${ }^{23}$ On average, firms paid 1.79 percent of their total production costs on bribery and spent 5.52 percent of total managerial time dealing with bureaucrats. Looking at different survey rounds, it can be observed that there is a slight increase of bribes paid as a share of production costs from 1.67 percent in the first survey round to 1.9 percent in the second survey round. At the same time, the percentage of managerial time spent with officials also increases from 4.80 percent to 5.71 percent. Naturally, there may be a 6 month inflation effect on bribe payments. However, since bribes are measured as percentages of total production costs, which are also affected by price level, the effect is controlled for. Table 2.1 further shows that even though the surveys are only six months apart, there were still slight adjustments on firm characteristics, such as the number of employees, structure of capital share and export-import activities.

\footnotetext{
${ }^{23}$ Out of the 470 firms that were interviewed in both rounds, the survey was able to collect the bribery information on 383 and 411 firms in the first and second rounds respectively. In the first round, 75 firms who admitted paying a very small amount of bribes compared to their total production cost agreed to state their answer as 0.000001 . Furthermore, three responses reported spending more than 60 percent of their managerial time on bureaucracy. As this is not likely to be the case, these firms were identified as outliers and therefore removed from the sample. This exclusion does not change the empirical result significantly.
} 
Table 2.1 Summary statistics

\begin{tabular}{lcccccccccc}
\hline & \multicolumn{3}{c}{ First survey round } & \multicolumn{2}{c}{ Second survey round } & \multicolumn{3}{c}{ Total } \\
\cline { 2 - 12 } & mean & std. & $\mathrm{n}$ & mean & std. & $\mathrm{n}$ & mean & std. & $\mathrm{n}$ \\
\hline Share of time spent with bureaucracy (percent) & 4.80 & 5.33 & 379 & 5.71 & 6.47 & 403 & 5.27 & 5.96 & 782 \\
Bribes (percent) & 1.67 & 4.36 & 379 & 1.90 & 4.26 & 403 & 1.79 & 4.31 & 782 \\
Age & 17.47 & 10.66 & 377 & 17.73 & 10.46 & 389 & 17.60 & 10.55 & 766 \\
Employees & 559 & 627.24 & 379 & 618 & 805.13 & 395 & 589 & 724 & 774 \\
Exporter or importer companies (dummy) & 0.78 & 0.42 & 379 & 0.77 & 0.42 & 403 & 0.77 & 0.42 & 782 \\
Government capital share (dummy) & 0.02 & 0.14 & 379 & 0.03 & 0.18 & 403 & 0.03 & 0.16 & 782 \\
Multinationals (dummy) & 0.45 & 0.50 & 377 & 0.41 & 0.49 & 399 & 0.43 & 0.50 & 776 \\
\hline
\end{tabular}

Table 2.2 presents the correlation matrix between variables. It shows that bribes, firm size, and export-import companies have a significant positive correlation with the share of managerial time spent with officials. As expected, the strongest correlation obtains between bribes and time spent with officials. Significant correlation also exists between the independent variables. In order to detect whether multicollinearity is an issue, different model specifications using different control variables are experimented with in the estimation.

Table 2.2 Correlation matrix

\begin{tabular}{llllllll}
\hline & \multicolumn{1}{l}{ (1) } & (2) & (3) & (4) & (5) & (6) & (7) \\
\hline (1) Share of time spent with bureaucracy (percent) & 1.00 & & & & & & \\
(2) Bribes (percent) & $0.37^{*}$ & 1.00 & & & & & \\
(3) Age & -0.03 & -0.01 & 1.00 & & & & \\
(4) Employees & $0.09^{*}$ & -0.02 & $0.08^{*}$ & 1.00 & & & \\
(5) Export-import companies (dummy) & $0.11^{*}$ & 0.05 & -0.05 & $0.20^{*}$ & 1.00 & & \\
(6) Government capital share (dummy) & -0.01 & -0.04 & $0.23^{*}$ & 0.06 & -0.05 & 1.00 & \\
(7) Multinationals (dummy) & 0.05 & 0.02 & $-0.19^{*}$ & $0.18^{*}$ & $0.27^{*}$ & -0.05 & 1.00 \\
\hline Note: * indicates that the correlation is significant at 5 percent confidence level. & & & & & &
\end{tabular}

Table 2.3 shows the panel estimation results using a random effects model as suggested by the Hausman test. When $\mathrm{T}$ is small and $\mathrm{N}$ is large, the random and fixed effects models generate different estimation results. Given that the data in this study have $\mathrm{T}=2$, further tests, such as the over-identifying restrictions test, suggested by Arellano (1993) and Wooldridge (2002), and the Brusch-Pagan test, are performed. Both tests further indicate that the random effects model is preferable. ${ }^{24}$

\footnotetext{
${ }^{24}$ Table B3 in the appendix presents the estimation results using different estimation technique, such as the fixed effects and first difference model. Further approach such as pooled estimation, interval regression and ordered probit also provide similar results in terms of coefficient sign and significance levels.
} 
Table 2.3 Panel random effects: Bribe payments and time spent with officials

\begin{tabular}{|c|c|c|c|c|c|c|c|c|c|}
\hline \multirow[t]{2}{*}{ Independent variables } & \multicolumn{8}{|c|}{ Random effect estimation } & \multirow[b]{2}{*}{ (9) } \\
\hline & $(1)$ & $(2)$ & (3) & (4) & (5) & (6) & $(7)$ & $(8)$ & \\
\hline Bribes & $\begin{array}{l}0.511 \text { *** } \\
(0.099)\end{array}$ & $\begin{array}{l}0.510^{* * *} \\
(0.043)\end{array}$ & $\begin{array}{l}{ }^{*} 0.507 * * * \\
(0.099)\end{array}$ & $\begin{array}{l}0.500^{* * *} \\
(0.101)\end{array}$ & $\begin{array}{l}0.510^{* * *} \\
(0.100)\end{array}$ & $\begin{array}{l}{ }^{*} 0.502 * * \\
(0.099)\end{array}$ & $\begin{array}{l}0.497 * * \\
(0.100)\end{array}$ & $\begin{array}{l}{ }^{k} 0.488^{* * *} \\
(0.105)\end{array}$ & $\begin{array}{l}{ }^{*} 0.485^{* * *} \\
(0.105)\end{array}$ \\
\hline Employees & & $\begin{array}{l}0.001 * \\
(0.000)\end{array}$ & $\begin{array}{l}0.001 * \\
(0.000)\end{array}$ & $\begin{array}{l}0.001 \\
(0.000)\end{array}$ & $\begin{array}{l}0.001 * \\
(0.000)\end{array}$ & $\begin{array}{l}0.000 \\
(0.000)\end{array}$ & $\begin{array}{l}0.000 \\
(0.000)\end{array}$ & $\begin{array}{l}0.001 \\
(0.000)\end{array}$ & $\begin{array}{l}0.001 \\
(0.000)\end{array}$ \\
\hline Employees squared & & $\begin{array}{l}-0.000 \\
(0.000)\end{array}$ & $\begin{array}{l}-0.000 \\
(0.000)\end{array}$ & $\begin{array}{l}-0.000 \\
(0.000)\end{array}$ & $\begin{array}{l}-0.000 \\
(0.000)\end{array}$ & $\begin{array}{l}-0.000 \\
(0.000)\end{array}$ & $\begin{array}{l}-0.000 \\
(0.000)\end{array}$ & $\begin{array}{l}-0.000 \\
(0.000)\end{array}$ & $\begin{array}{l}-0.000 \\
(0.000)\end{array}$ \\
\hline Age & & & $\begin{array}{l}0.017 \\
(0.032)\end{array}$ & $\begin{array}{l}0.019 \\
(0.033)\end{array}$ & $\begin{array}{l}0.023 \\
(0.033)\end{array}$ & $\begin{array}{l}0.011 \\
(0.032)\end{array}$ & $\begin{array}{l}0.015 \\
(0.034)\end{array}$ & $\begin{array}{l}0.008 \\
(0.036)\end{array}$ & $\begin{array}{l}0.003 \\
(0.037)\end{array}$ \\
\hline Age squared & & & $\begin{array}{l}-0.001 \\
(0.000)\end{array}$ & $\begin{array}{l}-0.001 \\
(0.000)\end{array}$ & $\begin{array}{l}-0.001 \\
(0.001)\end{array}$ & $\begin{array}{l}-0.000 \\
(0.000)\end{array}$ & $\begin{array}{l}-0.001 \\
(0.001)\end{array}$ & $\begin{array}{l}-0.001 \\
(0.001)\end{array}$ & $\begin{array}{l}-0.001 \\
(0.001)\end{array}$ \\
\hline Dummy: multinationals & & & & $\begin{array}{l}0.188 \\
(0.434)\end{array}$ & & & $\begin{array}{l}-0.022 \\
(0.444)\end{array}$ & $\begin{array}{l}-0.103 \\
(0.462)\end{array}$ & $\begin{array}{l}-0.181 \\
(0.505)\end{array}$ \\
\hline Dummy: has government share & & & & & $\begin{array}{l}1.399 \\
(1.118)\end{array}$ & & $\begin{array}{l}1.572 \\
(1.030)\end{array}$ & $\begin{array}{l}1.413 \\
(1.035)\end{array}$ & $\begin{array}{l}1.396 \\
(1.049)\end{array}$ \\
\hline Dummy: if export and/or import & & & & & & $\begin{array}{l}1.134 * * \\
(0.367)\end{array}$ & $\begin{array}{l}1.203^{* * *} \\
(0.385)\end{array}$ & $\begin{array}{l}{ }^{*} 1.265^{* * * *} \\
(0.398)\end{array}$ & $\begin{array}{l}\text { * } 1.252 * * * \\
(0.402)\end{array}$ \\
\hline Sector fixed effects & No & No & No & No & No & No & No & Yes & Yes \\
\hline Region fixed effects & No & No & No & No & No & No & No & No & Yes \\
\hline Number of observations & 924 & 915 & 906 & 902 & 906 & 906 & 902 & 894 & 894 \\
\hline Adjusted R2 & 0.1335 & 0.1381 & 0.1382 & 0.1332 & 0.1395 & 0.1444 & 0.1411 & 0.1441 & 0.1457 \\
\hline
\end{tabular}

Notes: The dependent variable is the share of managerial time spent with officials to expedite business (in percent). Constant terms are not shown; robust standard errors in parentheses. ${ }^{* * *} \mathrm{p}<0.01,{ }^{* *} \mathrm{p}<0.05,{ }^{*} \mathrm{p}<0.1$.

In column 1, variable bribe is included as the only regressor. The result shows that the amount of bribes paid is a positive and significant determinant of the amount of managerial time spent with the public officials. An increase in the bribes ratio per total production cost of one percentage point is associated with an increase in the share of managerial time spent with officials for 0.51 percentage points. In the later columns, different specifications are experimented with, and the same result is always obtained after controlling for firm-level variables. In column 6, when the dummy variable export-import company is included, the bribes coefficient declines to 0.502 , but remains positive and significant. The coefficient of the export-import dummy variable turns out to be positive and significant, which indicates that the export-import companies that deal extensively with the customs office explain a significant portion of the variation of the managerial time spent officials. In column 9, the specification further controls for all firm characteristics, including the sector and region fixed effects. The coefficient of bribes declines to 0.485 but remains significant at the 1 percent level. This implies that a one percentage point increase in the bribes ratio per total production cost increases the share of managerial time spent with bureaucracy by about 0.49 percentage points. As for the control variables, there is a tiny positive and significant effect 
of the size of the labor force in the company. Even though the sample used in the analysis consists of medium-large firms that face a similar set of labor regulations, larger firms apparently receive more "supervision” from the public officials.

Table 2.4 2SLS regressions: Bribe payments and time spent with officials

\begin{tabular}{llllllllll}
\hline Independent variables & \multicolumn{1}{c}{ 2SLS Estimation } \\
\cline { 2 - 9 } & $(1)$ & $(2)$ & (3) & (4) & (5) & (6) & (7) & (8) & (9) \\
\hline
\end{tabular}

Second stage, the dependent variable is the ratio of time spent with officials

\begin{tabular}{|c|c|c|c|c|c|c|c|c|c|}
\hline Bribes & & & $0.698 * * *$ & $0.691^{* * *}$ & $0.699 * * *$ & $0.684 * * *$ & $0.670^{* * *}$ & $0.524 * * *$ & $0.510^{* * *}$ \\
\hline & $(0.123)$ & $(0.123)$ & $(0.119)$ & $(0.127)$ & $(0.118)$ & $(0.122)$ & $(0.130)$ & $(0.201)$ & $(0.193)$ \\
\hline Employees & & $0.002 * *$ & $0.002^{* *}$ & $0.002 * *$ & $0.002 * *$ & $0.002 *$ & $0.002 *$ & $0.002 *$ & $0.002 *$ \\
\hline & & $(0.001)$ & $(0.001)$ & $(0.001)$ & $(0.001)$ & $(0.001)$ & $(0.001)$ & $(0.001)$ & $(0.001)$ \\
\hline Employee squared & & $-0.000 * *$ & $-0.000 * *$ & $-0.000 * *$ & $-0.000 * *$ & $-0.000^{*}$ & $-0.000 *$ & $-0.000 *$ & $-0.000 * *$ \\
\hline & & $(0.000)$ & $(0.000)$ & $(0.000)$ & $(0.000)$ & $(0.000)$ & $(0.000)$ & $(0.000)$ & $(0.000)$ \\
\hline Age & & & 0.071 & 0.053 & 0.083 & 0.057 & 0.041 & 0.024 & 0.040 \\
\hline & & & $(0.095)$ & $(0.099)$ & $(0.097)$ & $(0.094)$ & $(0.100)$ & $(0.106)$ & $(0.111)$ \\
\hline Age squared & & & -0.003 & -0.003 & -0.003 & -0.003 & -0.003 & -0.002 & -0.003 \\
\hline & & & $(0.002)$ & $(0.002)$ & $(0.002)$ & $(0.002)$ & $(0.002)$ & $(0.002)$ & $(0.003)$ \\
\hline Dummy: multinationals & & & & -0.542 & & & -0.790 & -0.634 & -0.760 \\
\hline & & & & $(0.728)$ & & & $(0.744)$ & $(0.818)$ & $(0.898)$ \\
\hline Dummy: has government share & & & & & 1.146 & & 1.484 & 0.820 & 0.891 \\
\hline & & & & & (1.183) & & $(1.025)$ & (1.228) & (1.155) \\
\hline Dummy: if export and/or import & & & & & & $1.260^{* *}$ & $1.601^{* *}$ & $1.889 * * *$ & $1.701^{* *}$ \\
\hline & & & & & & $(0.640)$ & $(0.688)$ & $(0.731)$ & $(0.745)$ \\
\hline
\end{tabular}

First stage, the dependent variable is bribes

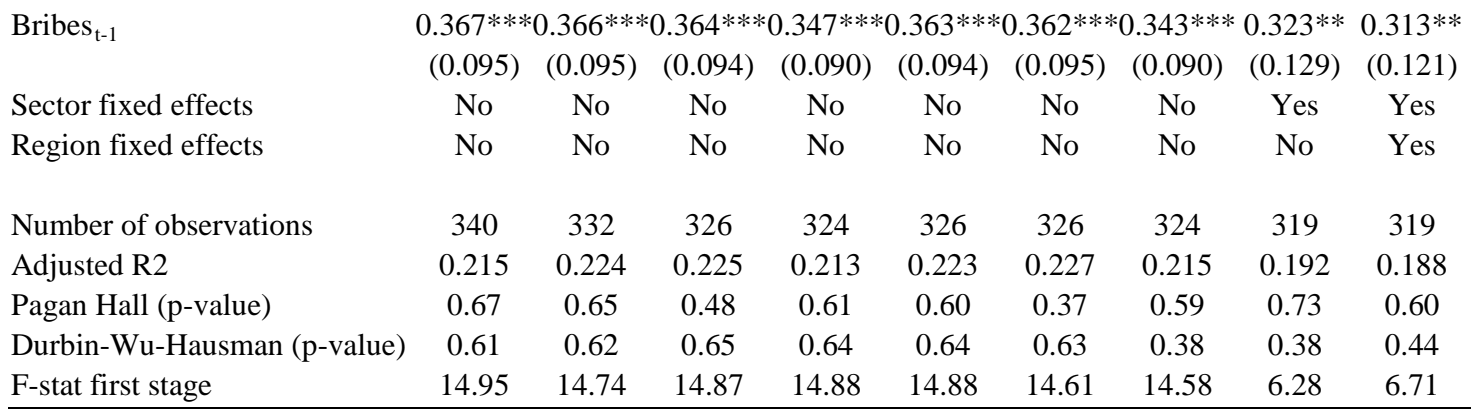

Notes: IV estimates are reported. Coefficients are reported with robust standard errors in parentheses, constant terms not shown. F-stat first stage is the joint probability of an F-test for the first stage regressions. ${ }^{* * *} \mathrm{p}<0.01,{ }^{* *} \mathrm{p}<0.05,{ }^{*} \mathrm{p}<0.1$.

In order to sort out the potential reverse causality between bribes and the time spent with an official, the bribes paid in the previous round (round 1) is used to instrument the current bribes (round 2). Repeating the key regression used in Table 2.3, Table 2.4 shows that the bribes coefficient remains positive and significant with a higher magnitude. ${ }^{25}$ Controlling for

\footnotetext{
${ }^{25}$ It should be noted that the Durbin-Wu-Hausman test consistently gives p-value above 0.1, which indicates that it fails to reject the null hypothesis that the variable bribe is exogenous. This means that the OLS technique
} 
firm characteristics as well as sector and region fixed effects (column 9), the result obtains a slope coefficient of 0.51 , which is significant at the 1 percent level. The reported first stage F-statistics for the specifications without fixed effects indicates that the quality of the instrumental variable is quite good. However, once the specification controls for the sector and region fixed effects, the F-statistics decline to below 10, raising a small concern regarding the strength of the instrument. Nevertheless, as the coefficient of the main variable bribes remains positive and significant, it can be argued that the 2SLS results are a little bit problematic due to the weak instrument issue, but the results reinforce the basic findings of random effects estimation. ${ }^{26}$

The study subsequently tests the possibility of non-linear relationships between the key elements of the "grease the wheels" hypothesis. In Table 2.5, the squared value of variable bribes is included in the specification. The results show that there is a non-linear relationship between bribes payments and time spent with officials. In columns 1 to 4 , the results of random effects are reported. Comparing the full model in column 4 and column 9 in table 4, the results show that the magnitude of the bribe's coefficient increases to 0.75 while the squared term coefficient is -0.01 , both significant at the 1 percent level. This suggests that the share of managerial time spent with official increases with the size of the bribes at a decreasing rate until it reaches a turning point at 34.14 percentage points (still in the sample). Beyond this value, higher bribes may reduce the time spent with officials. The estimation of the non-linear specification using the fixed effects model also confirms this finding, even though the effect seems to fade away when the model controls for firm characteristics and sector fixed effects (column 7). ${ }^{27}$

\footnotetext{
gives a more consistent estimation. Nevertheless, given the potential reverse causality between variable bribe and the dependent variable, the 2SLS estimation results are still relevant (full results are shown in Table B4).

${ }^{26}$ It is acknowledged that these results ultimately confirm the positive relationship between bribe payments and the amount of time spent with officials, which supposed to survive from the endogeneity issues. However, one could certainly argue that using lagged bribes may not be sufficient, as it may be the case that lagged bribes are affected by the same unobserved factors as the present bribes.

${ }^{27}$ The non-linear effect is also not found in the 2SLS results (Appendix 4).
} 
Table 2.5 Non-linear relationship between the amount of bribes paid and the time spent with officials.

\begin{tabular}{|c|c|c|c|c|c|c|c|}
\hline & (1) & (2) & (3) & (4) & (5) & (6) & (7) \\
\hline & $\mathrm{RE}$ & $\mathrm{RE}$ & $\mathrm{RE}$ & $\mathrm{RE}$ & FE & FE & FE \\
\hline Bribes & $0.784 * * *$ & $0.759 * * *$ & $0.750 * * *$ & $0.751 * * *$ & $0.706^{* * *}$ & $0.660 * * *$ & 0.277 \\
\hline & (0.119) & $(0.123)$ & $(0.121)$ & $(0.121)$ & $(0.202)$ & $(0.210)$ & $(0.277)$ \\
\hline Bribes squared & $-0.011^{* * *}$ & $-0.011^{* * *}$ & $-0.011^{* * *}$ & $-0.011^{* * *}$ & $-0.011 * *$ & $-0.010^{*}$ & 0.011 \\
\hline & $(0.004)$ & $(0.004)$ & $(0.004)$ & $(0.004)$ & $(0.005)$ & $(0.006)$ & $(0.014)$ \\
\hline Employees & & 0.000 & 0.001 & 0.001 & & $0.008 * * *$ & $0.010 * * *$ \\
\hline & & $(0.000)$ & $(0.000)$ & $(0.000)$ & & $(0.003)$ & $(0.004)$ \\
\hline Employees squared & & -0.000 & -0.000 & -0.000 & & $-0.000 * * *$ & $-0.000 * * *$ \\
\hline & & $(0.000)$ & $(0.000)$ & $(0.000)$ & & $(0.000)$ & $(0.000)$ \\
\hline Age & & 0.015 & 0.008 & 0.003 & & -0.055 & -0.083 \\
\hline & & $(0.034)$ & $(0.036)$ & $(0.038)$ & & $(0.095)$ & $(0.105)$ \\
\hline Age squared & & -0.001 & -0.001 & -0.001 & & -0.000 & -0.000 \\
\hline & & $(0.001)$ & $(0.001)$ & $(0.001)$ & & $(0.001)$ & $(0.001)$ \\
\hline Dummy: multinationals & & 0.024 & -0.059 & -0.119 & & 0.243 & 0.084 \\
\hline & & $(0.445)$ & $(0.461)$ & $(0.505)$ & & $(1.284)$ & (1.239) \\
\hline Dummy: has government share & & $1.702 *$ & 1.557 & 1.543 & & -0.336 & -0.667 \\
\hline & & $(0.993)$ & $(1.003)$ & $(1.014)$ & & $(2.185)$ & (2.083) \\
\hline Dummy: if export and/or import & & $1.173 * * *$ & $1.234 * * *$ & $1.219 * * *$ & & 0.925 & 1.040 \\
\hline & & $(0.383)$ & $(0.395)$ & $(0.399)$ & & $(0.872)$ & $(0.991)$ \\
\hline Sector fixed effects & no & no & yes & yes & no & no & Yes \\
\hline Region fixed effects & no & no & no & yes & no & no & no \\
\hline Number of Obs. & 924 & 902 & 894 & 894 & 924 & 902 & 894 \\
\hline Adjusted R2 & 0.146 & 0.153 & 0.153 & 0.155 & 0.062 & 0.070 & 0.079 \\
\hline
\end{tabular}

Notes: The dependent variable is the share of managerial time spent with officials to deal with bureaucracy. Robust standard errors in parentheses, constant terms are not shown. ${ }^{* * *} \mathrm{p}<0.01,{ }^{* *} \mathrm{p}<0.05,{ }^{*} \mathrm{p}<0.1$.

\subsubsection{Competitive bribery with asymmetric information}

In Table 2.6, the results of the competitive bribery with an asymmetric information framework are presented. In this framework, I examine whether officials will grant reduced bureaucracy to those who pay larger bribes than the firm-specific average bribe. In order to test this, the bribe variable is estimated using firm characteristics, as well as sector and regional fixed effects. The predicted residuals $\left(\hat{\varepsilon}_{i t}\right)$ of this estimation represent the difference between the bribes paid and the average bribe. The obtained $\hat{\varepsilon}_{i t}$ is subsequently included as a regressor to estimate the time spent with officials, replacing the bribe variable. Column 2 shows that the coefficient $\widehat{\varepsilon}_{\text {it }}$ is positive and statistically significant at the 1 percent level. Further controlling for firm characteristics as well as fixed effects, the magnitude and significances of the coefficient $\widehat{\varepsilon}_{\text {it }}$ do not change considerably. In column 9, the coefficient $\hat{\varepsilon}_{\text {it }}$ is 0.485 , which indicates that a 1 percentage point increase in the difference between the actual and predicted bribe is associated with an increase in the share of managerial time 
spent with officials of about 0.49 percentage points. This finding is again inconsistent with the "grease the wheels" hypothesis. Firms that pay larger bribes are the ones discriminated against by public officials, who cause them to waste more time in dealing with bureaucracy. It is true that by categorizing firms based on the value of $\hat{\varepsilon}_{\text {it }}$ into quartiles $\left(\mathrm{Q}_{1}, \mathrm{Q}_{2}, \mathrm{Q}_{3}\right.$ and $\mathrm{Q}_{4}$ ), column 10 shows that firms in the highest quartiles spent significantly more time with officials. Column 11 shows the estimation results from the fixed effects model and seconds the findings.

A potential problem with this empirical strategy stems from the potential endogeneity issue. For instance, there is a possibility that the amount of bribes paid in the first period influences the effectiveness of the public officials (time spent with the officials), which then affects some of the firm-level variables in the second period. To address this concern, a separate regression in each survey period is performed. First, the variable Bribes is estimated using firm characteristics on the basis of the first round sub-samples (column 12). Second, the predicted firm-specific residual obtained from the first step is then included as a regressor to estimate the time spent with officials using the second round sub-samples (column 13). In this way, the predicted residual $\hat{\varepsilon}_{i t-1}$ is predetermined and therefore may resolve the endogeneity issue.

Columns 12 to 14 show the results of the OLS estimation of the cross-sectional model. Again, column 13 confirms the clear positive relationship between the predicted residuals and the time spent with officials but smaller in size. Focusing on the quartiles dummy variables, the results also confirm the previous findings with even more significant results. Column 14 shows that the size of the quartile's coefficient increases with each quartile category. The larger the bribe a firm pays compared to its predicted bribes, the more time the firm spends with officials. One possible explanation of this finding is that greedy officials may target the "weak" firms that are less reluctant to pay high bribes. Thus, officials may deliberately impose administrative delays. 
Table 2.6 Competitive bribery with asymmetric information

\begin{tabular}{|c|c|c|c|c|c|c|c|c|c|c|c|c|c|c|}
\hline \multirow{3}{*}{ Dependent variable: } & (1) & (2) & (3) & (4) & (5) & (6) & (7) & (8) & (9) & (10) & (11) & (12) & (13) & (14) \\
\hline & Bribes & Time & Time & Time & Time & Time & Time & Time & Time & Time & Time & Bribes & Time & Time \\
\hline & \multicolumn{10}{|c|}{$\mathrm{RE}$} & $\mathrm{FE}$ & OLS & OLS & OLS \\
\hline Employees & $\begin{array}{l}-0.000 \\
(0.000)\end{array}$ & $\begin{array}{l}0.001^{*} \\
(0.000)\end{array}$ & $\begin{array}{l}0.001^{*} \\
(0.000)\end{array}$ & $\begin{array}{c}0.001 \\
(0.000)\end{array}$ & $\begin{array}{l}0.001^{*} \\
(0.000)\end{array}$ & $\begin{array}{c}0.000 \\
(0.000)\end{array}$ & $\begin{array}{c}0.000 \\
(0.000)\end{array}$ & $\begin{array}{c}0.001 \\
(0.000)\end{array}$ & $\begin{array}{c}0.001 \\
(0.000)\end{array}$ & $\begin{array}{c}0.001 \\
(0.000)\end{array}$ & $\begin{array}{c}0.009 * * * \\
(0.003)\end{array}$ & $\begin{array}{l}-0.000 \\
(0.000)\end{array}$ & $\begin{array}{c}0.003^{* * *} \\
(0.001)\end{array}$ & $\begin{array}{c}0.003^{* * *} \\
(0.001)\end{array}$ \\
\hline Employees squared & $\begin{array}{l}-0.000 \\
(0.000)\end{array}$ & $\begin{array}{l}-0.000 \\
(0.000)\end{array}$ & $\begin{array}{l}-0.000 \\
(0.000)\end{array}$ & $\begin{array}{l}-0.000 \\
(0.000)\end{array}$ & $\begin{array}{l}-0.000 \\
(0.000)\end{array}$ & $\begin{array}{l}-0.000 \\
(0.000)\end{array}$ & $\begin{array}{l}-0.000 \\
(0.000)\end{array}$ & $\begin{array}{l}-0.000 \\
(0.000)\end{array}$ & $\begin{array}{l}-0.000 \\
(0.000)\end{array}$ & $\begin{array}{l}-0.000 \\
(0.000)\end{array}$ & $\begin{array}{c}-0.000^{* * *} \\
(0.000)\end{array}$ & $\begin{array}{l}-0.000 \\
(0.000)\end{array}$ & $\begin{array}{c}-0.000^{* *} \\
(0.000)\end{array}$ & $\begin{array}{c}-0.000^{* *} \\
(0.000)\end{array}$ \\
\hline Age & $\begin{array}{l}-0.028 \\
(0.036)\end{array}$ & & $\begin{array}{c}0.007 \\
(0.032)\end{array}$ & $\begin{array}{c}0.011 \\
(0.034)\end{array}$ & $\begin{array}{c}0.009 \\
(0.033)\end{array}$ & $\begin{array}{l}-0.001 \\
(0.032)\end{array}$ & $\begin{array}{c}0.001 \\
(0.034)\end{array}$ & $\begin{array}{l}-0.002 \\
(0.035)\end{array}$ & $\begin{array}{l}-0.011 \\
(0.037)\end{array}$ & $\begin{array}{l}-0.034 \\
(0.038)\end{array}$ & $\begin{array}{c}-0.179 * \\
(0.108)\end{array}$ & $\begin{array}{l}-0.022 \\
(0.044)\end{array}$ & $\begin{array}{l}-0.016 \\
(0.129)\end{array}$ & $\begin{array}{l}-0.066 \\
(0.127)\end{array}$ \\
\hline Age squared & $\begin{array}{c}0.000 \\
(0.000)\end{array}$ & & $\begin{array}{l}-0.000 \\
(0.000)\end{array}$ & $\begin{array}{l}-0.001 \\
(0.000)\end{array}$ & $\begin{array}{l}-0.001 \\
(0.001)\end{array}$ & $\begin{array}{l}-0.000 \\
(0.000)\end{array}$ & $\begin{array}{l}-0.000 \\
(0.000)\end{array}$ & $\begin{array}{l}-0.000 \\
(0.001)\end{array}$ & $\begin{array}{l}-0.000 \\
(0.001)\end{array}$ & $\begin{array}{c}0.000 \\
(0.001)\end{array}$ & $\begin{array}{c}0.000 \\
(0.001)\end{array}$ & $\begin{array}{c}0.000 \\
(0.001)\end{array}$ & $\begin{array}{l}-0.002 \\
(0.003)\end{array}$ & $\begin{array}{l}-0.000 \\
(0.003)\end{array}$ \\
\hline Dummy: multinationals & $\begin{array}{c}0.009 \\
(0.415)\end{array}$ & & & $\begin{array}{c}0.211 \\
(0.441)\end{array}$ & & & $\begin{array}{l}-0.062 \\
(0.450)\end{array}$ & $\begin{array}{l}-0.109 \\
(0.462)\end{array}$ & $\begin{array}{l}-0.177 \\
(0.505)\end{array}$ & $\begin{array}{l}-0.019 \\
(0.508)\end{array}$ & $\begin{array}{c}0.472 \\
(1.164)\end{array}$ & $\begin{array}{c}0.121 \\
(0.463)\end{array}$ & $\begin{array}{l}-0.201 \\
(0.865)\end{array}$ & $\begin{array}{l}-0.095 \\
(0.868)\end{array}$ \\
\hline Dummy: has government share & $\begin{array}{c}-1.125^{* *} \\
(0.481)\end{array}$ & & & & $\begin{array}{c}0.676 \\
(1.123)\end{array}$ & & $\begin{array}{c}0.920 \\
(1.009)\end{array}$ & $\begin{array}{c}0.866 \\
(1.023)\end{array}$ & $\begin{array}{c}0.851 \\
(1.046)\end{array}$ & $\begin{array}{c}-0.265 \\
(1.106)\end{array}$ & $\begin{array}{l}-1.127 \\
(2.018)\end{array}$ & $\begin{array}{l}-0.168 \\
(0.523)\end{array}$ & $\begin{array}{c}2.179 * * \\
(1.014)\end{array}$ & $\begin{array}{c}2.008^{* *} \\
(1.019)\end{array}$ \\
\hline Dummy: if export and/or import & $\begin{array}{l}0.515^{*} \\
(0.298)\end{array}$ & & & & & $\begin{array}{c}1.475^{* * * *} \\
(0.371)\end{array}$ & $\begin{array}{c}1.512^{* * *} \\
(0.387)\end{array}$ & $\begin{array}{c}1.529 * * * \\
(0.399)\end{array}$ & $\begin{array}{c}1.502^{* * *} \\
(0.401)\end{array}$ & $\begin{array}{c}1.738 * * * \\
(0.436)\end{array}$ & $\begin{array}{c}1.805^{* *} \\
(0.853)\end{array}$ & $\begin{array}{l}-0.444 \\
(1.511)\end{array}$ & $\begin{array}{c}0.079 \\
(2.302)\end{array}$ & $\begin{array}{c}0.009 \\
(2.300)\end{array}$ \\
\hline$\widehat{\varepsilon_{t}}$ & & $\begin{array}{c}0.483^{* * *} \\
(0.105)\end{array}$ & $\begin{array}{c}0.484^{* * * *} \\
(0.105)\end{array}$ & $\begin{array}{c}0.484 * * * \\
(0.105)\end{array}$ & $\begin{array}{c}0.484^{* * *} \\
(0.105)\end{array}$ & $\begin{array}{c}0.485^{* * *} \\
(0.105)\end{array}$ & $\begin{array}{c}0.486^{* * *} \\
(0.105)\end{array}$ & $\begin{array}{c}0.486^{* * *} \\
(0.104)\end{array}$ & $\begin{array}{c}0.485^{* * *} \\
(0.105)\end{array}$ & & & & $\begin{array}{c}0.249 * * \\
(0.109)\end{array}$ & \\
\hline$Q_{2}$ & & & & & & & & & & $\begin{array}{l}-0.719 \\
(0.519)\end{array}$ & $\begin{array}{l}-0.222 \\
(1.069)\end{array}$ & & & $\begin{array}{l}2.234^{*} \\
(1.206)\end{array}$ \\
\hline$Q_{3}$ & & & & & & & & & & $\begin{array}{c}0.472 \\
(0.615)\end{array}$ & $\begin{array}{c}0.036 \\
(1.299)\end{array}$ & & & $\begin{array}{l}2.244^{*} \\
(1.192)\end{array}$ \\
\hline$Q_{4}$ & & & & & & & & & & $\begin{array}{c}3.616^{* * *} \\
(0.708)\end{array}$ & $\begin{array}{c}2.511^{* *} \\
(1.154)\end{array}$ & & & $\begin{array}{c}3.080^{* * *} \\
(1.147)\end{array}$ \\
\hline Sector fixed effects & Yes & No & No & No & No & No & No & Yes & Yes & Yes & Yes & Yes & Yes & Yes \\
\hline Region fixed effects & Yes & No & No & No & No & No & No & No & Yes & Yes & Yes & Yes & Yes & Yes \\
\hline Number of Obs. & 894 & 894 & 894 & 894 & 894 & 894 & 894 & 894 & 894 & 894 & 894 & 472 & 340 & 340 \\
\hline Adjusted R2 & 0.032 & 0.120 & 0.121 & 0.121 & 0.121 & 0.131 & 0.132 & 0.141 & 0.146 & 0.107 & 0.034 & 0.009 & 0.052 & 0.053 \\
\hline
\end{tabular}




\subsection{Conclusion}

This paper investigates the "grease the wheels" hypothesis of corruption by examining the effect of illegal bribe payments on the effectiveness of public service delivery. Analyzing information from 470 firms in Indonesia, this study finds results inconsistent with the "grease the wheels" hypothesis, though a non-linear relationship is found. Sorting out the reverse causality problem, this study still finds no evidence that supports the hypothesis.

The study further examines the context of the competitive bribery under imperfect information, which is relevant for the case of Indonesia, a country with a long history of corruption. This paper argues that when there is asymmetric information, a corrupt official may consider the firm's type in granting a shorter bureaucracy waiting time. The econometric analysis suggests that firms that pay larger bribes compared to the average bribe face further bureaucratic delays.

Profit maximizing firms will not pay bribes if they are higher than they can afford. The "weak" firms might do so for several reasons. It could be that firms are frustrated and want to accelerate slow services; or that firms are hiding illegal activities and need to collude with public officials; or that firms that pay bribes also need to spend time simultaneously with officials to smooth business activities. The extent to which these reasons are operative has not been investigated in this study, but these questions suggest a great potential for future research to provide a better understanding of the motivations of firms in terms of bribery transactions, as well as in identifying the official's selection properties in granting less or more bureaucracy’s burden. 


\section{Women in power: Do women politicians stand up for their female voters? ${ }^{28}$}

\section{Abstract}

This paper examines whether higher representation of women in a locally elected group of community representatives is likely to shape policy outcomes. The median voter theorem predicts that in a perfect indirect democracy, the platforms of elected representatives represent the preferences of the median voter, and therefore the politician's identity would not necessarily matter. This paper empirically tests the theory by using ex-ante data on the preferences of both households and elected representatives toward different poverty programs offered by a nationwide community-driven development project in Indonesia, the Urban Poverty Project 2. We find that in most cases, the preferences of the median voter do not matter for policy outcomes, but in some cases they do. We show that the proportion of the project budget allocated to education, health and irrigation programs is higher in communities where the median voter is concerned about this issue. Furthermore, we find that the female proportion of representatives is irrelevant for policy outcomes, but does facilitate the preferences of the median voter and particularly the preferences of female voters who request improvements in public sanitation.

\footnotetext{
${ }^{28}$ This paper is based on joint work with Stephan Klasen.
} 


\subsection{Introduction}

There is a substantial literature demonstrating that women have different political interests from men, as expressed in their voting and leadership behavior. These differences can be derived from the traditional intra-household division of tasks, which limits women's participation in the job market, and consequently makes them more vulnerable to poverty following divorce or the death of a partner. Empirically, Edlund and Pande (2002) show a strong positive relationship between state divorce prevalence and women's support for the Democratic Party, which promotes transfer and income redistribution policies. A similar result is obtained by Alesina and La Ferrara (2005), who show that women are generally supportive of redistributive policies, as they are less likely to pay taxes and more likely to receive benefits.

Even though the most of evidence indicates that women have different preferences concerning political outcomes (e.g. Lott and Kenny, 1999; Svaleryd, 2009), women are still underrepresented in politics, particularly in developing countries. Social norms that dictate that women should follow men, religious beliefs that require that society not be led by women, or internalized stereotypes have caused women to be marginalized from political positions, which restrains them from voicing their own choices. Indeed, granting more political access to women may increase women's ability to make choices through more inclusive and representative institutions (World Bank, 2012). However, little is known about whether female representation will lead to policy outcomes that are more responsive to women’s needs.

The median voter theorem proposed by Downs (1957) states that in a perfect democracy, the elected politician is the one whose platform represents the preferences of the median voter. Under this model, a politician's identity is irrelevant to shaping political outcomes, since only the preferences of the median voter matter. Nevertheless, an elected politician can only enact the policy commitment once she is in office. It remains uncertain whether the politician will credibly commit to the median voter's preferences if doing so would oppose the politician's own interests. Thus, the median voter theory has been criticized for its rather restrictive policy commitment. In an alternative economic model of representative democracy (the citizen candidate model), Besley and Coate (1997) and Osborne and Slivinski (1996) relax the assumption of complete policy commitment, by allowing for the 
role of a politician's character as an important factor in policy outcomes. Similarly, Levitt (1996) examines whether senators' identities shape the policies that they support and shows that a senator's own ideology becomes the most important factor of roll-call voting patterns, while voter preferences reflect only one quarter weight in the politician’s utility function.

Several studies provide evidence about the effect of a politician's gender on policy outcomes. In the context of the women reservation policy in India's village council, Chattopadhyay and Duflo (2004) found that allocating leadership positions exclusively to women leads to more resource allocation for programs that matter more to women. However, Sathe et al. (2013) show that the impact of this policy takes time to develop, as women need first to build up experience, in order to ensure service availability for women. In a different context, Rehavi (2007) finds that an increase in the number of women in US state legislatures caused significant rise in health spending, while in the context of Swedish local councils, it increases childcare and education spending relative to elderly care (Svaleryd, 2009). To sum up, most of the available empirical studies only focus on the roles of females as politicians or females as voters, and their impacts on policy outcomes.

There are only a few studies that focus on the relevance of the voter's gender differences in preferences, and relate this to differences in preferences of male and female politicians, and how these factors simultaneously influence policy outcomes. ${ }^{29}$ Analyzing the gender gap in differences is important, because if female politicians' preferences were the same as those of male politicians, a reservation policy for women would not be necessary. Duflo (2004) illustrates the case where different gender preferences may not translate into different political views: “... a household where members could promise to each other that they would vote in a certain way ought to cast their votes in such a way as to maximize the expected value of the bundle of policies chosen for the household as a whole. A member who benefits more from the policy can supply compensation for the other's vote. In this world, there would be no difference in the expressed policy preferences of (married) women and men." Acknowledging this issue, a comprehensive analysis of gender differences in the preferences

\footnotetext{
${ }^{29}$ Funk and Gathmann (2006) examine the intensive democracy system in Switzerland, where all citizens can directly decide on a broad range of policies in referenda and initiatives. They use the voting decisions data to capture voter preferences, analyze the gender gap in the preferences of voters toward a range of policies, and relate this to the effect of women as policy makers on the composition of public spending. Chattopadhyay and Duflo (2004) use the number of formal requests and complaints brought to the Pradhan as a proxy for community preferences. They use this information to analyze whether women policy makers are more responsive to issues brought forward by women in these communities.
} 
of both voters and politicians may improve our understanding of the effectiveness of women-reservation policies in representative democracies.

This study contributes to the literature by empirically considering the link between female representation and female preferences, and its impact on policy outcomes, in the context of the median voter theorem. In this paper, we first explore whether median voter preferences matter for allocating resources. Second, we investigate whether higher female representatives results in policy outcomes that are more responsive to women's needs. Using data from 154 communities in Indonesia, we analyze the ex-ante preferences of both voters and elected representatives toward eight programs offered by a nationwide communitydriven development program in Indonesia, the Urban Poverty Project 2 (UPP2). To the best of our knowledge, our study is the first to attempt to test the Downsian model under representative democracy using ex-ante preference data for both voters and policy makers.

Our empirical analyses find that in most cases, the median voter's preferences do not matter to policy outcomes, but in some cases they do. We show that the portion of the UPP2 budget that goes to education, health and irrigation programs is higher in communities where the median voter raises the issue in relation to this particular program. Furthermore, we find that the proportion of local representatives who are female is not the main driver of changes in the UPP2 budget composition. However, an increased movement of women into local representative office does facilitate the preferences of the median voter, and particularly the preferences of female voters who request more attention to public sanitation. One possible reason for the small effect of female representatives is that the preferences of female and male representatives are similar, and that they differ only on issues related to public sanitation, but not more generally. Our results suggest that although median voter preferences matter to policy outcomes, the gender of the politician is the most important determinant of resource allocation, specifically on programs that matter most for women. Thus, our study casts doubt on the empirical relevance of the median voter theorem in this respect.

The rest of this paper proceeds as follows. The next section will discuss the mechanism of UPP2. Section 3 discusses the empirical strategy used to examine the effect of the median voter and female representatives on policy outcomes. Section 4 describes the data and presents some descriptive statistics. Section 5 presents the central results of this study. Section 6 concludes the study. 


\subsection{The selection of representatives and anti-poverty programs in UPP2}

The Urban Poverty Project 2 (UPP2) is an Indonesian nationwide poverty alleviation program that was implemented between 2004 and 2007, aiming to minimize the impact of the Asian financial crisis on urban poverty. Expanding the coverage of its precursor, UPP2 allocated US\$127 million to around 2,000 urban kelurahans or "urban village" in 13 provinces, so that each kelurahan had access to a one-time grant allocation of up to around US\$55,000, depending on the size of the population. ${ }^{30}$ UPP2 adopts the community-driven development approach by promoting community participation, defining poverty according to community criteria, and choosing poverty alleviation programs through their mandated representatives in the community institution fostered by UPP2, called the BKM (Badan Keswadayaan Masyarakat or board of community trustees).

In every kelurahan, there is one BKM consisting of 9 to 14 board members who are delegated the authority to manage UPP2 resources. Furthermore, to ensure female representation in the BKM, UPP2 recommends that at least one-third of BKM members be women. However, the strategy seems not to have been fully successful, since only 16.34 percent of the elected board members were women, far less than the 49 percent of female voters, although still higher than women's representation in the national parliament in 2004 (around 11.3 percent).

Given the central importance of the BKM, the process of electing members was organized in a participatory manner. At the initial stage of project implementation, communities were asked to think about the qualities that a leader should have and name a person in their neighborhood that possessed such qualities to be nominated as a BKM member. The names were then submitted to the kelurahan meeting at which communities subsequently voted through a secret ballot. Finally, the winners of the election serve as unpaid BKM members who are delegated the authority to allocate UPP2 resources.

\footnotetext{
${ }^{30}$ Indonesia is divided into 33 provinces, which in turn are composed of districts. Each district is further broken down into sub-districts. Below the sub-district level, there are villages and urban villages called kelurahan. Typically, a kelurahan is divided non-administratively into several neighborhoods (RW) that consists of several wards (RT). Each ward manages a certain number of households.
} 
To ensure that communities expressed their preferences regarding the types of programs that should be implemented, local residents could participate in a community discussion, led by BKM members, to form a Community Development Plan (CDP) containing poverty reduction strategies for the next three years. Residents could also submit their own project proposals to BKM members if the CDP did not cover their preferences. Afterwards, project selection and funding allocation were decided by BKM members through an internal decision-making process.

Table 3.1 Classification of UPP2 programs

\begin{tabular}{|c|c|c|}
\hline Sector & Program type & Project description \\
\hline \multirow{5}{*}{ Infrastructure } & 1. Roads/bridges & New construction or rehabilitation of roads/bridges. \\
\hline & 2. House improvement & Rehabilitation of residential houses of the vulnerable poor. \\
\hline & 3. Public sanitation & Drainage, public toilets, non-permanent garbage facilities. \\
\hline & $\begin{array}{l}\text { 4. Water, public } \\
\text { lighting }\end{array}$ & $\begin{array}{l}\text { Construction or rehabilitation of community's clean water, water } \\
\text { tanks, public lighting, etc. }\end{array}$ \\
\hline & $\begin{array}{l}\text { 5. Education, health } \\
\text { and irrigation } \\
\text { facilities }\end{array}$ & $\begin{array}{l}\text { Infrastructure related projects, mostly on education, health and } \\
\text { irrigation facilities. }\end{array}$ \\
\hline \multirow{2}{*}{ Social } & 6. Welfare programs & $\begin{array}{l}\text { Grant assistance to specific individuals identified as being most } \\
\text { needy or vulnerable, including support for orphans, the elderly, and } \\
\text { the poor, in the form of scholarships, health care, etc. }\end{array}$ \\
\hline & 7.Trainings & $\begin{array}{l}\text { Support for training or informal education to improve skills among } \\
\text { the poor. }\end{array}$ \\
\hline Economic & 8.Microfinance & $\begin{array}{l}\text { Small scale manufacturing support (i.e. small scale shoe factory, } \\
\text { clothing, handbags, pottery, and support for petty trade such as } \\
\text { selling cooked/fresh food, services such as electronics repair, } \\
\text { tailoring, etc.) }\end{array}$ \\
\hline
\end{tabular}

Source: The MIS glossary.

According to the UPP2 Monitoring Information System (MIS), the projects accomplished are sorted into 3 sectors, namely infrastructure, social, and economic sectors, which further break down into 11 programs, with each program consisting of several activities. For simplification, we re-classified the program types into eight programs, as described in Table 3.1. ${ }^{31}$

\footnotetext{
${ }^{31}$ In the MIS data, the UPP2 program's disbursement is classified into: (1) roads/bridges, (2) housing, (3) sanitation, (4) water and public lighting, (5) infrastructure others (education, health and irrigation facilities), (6) training, (7) poverty grants, (8) social others, (9) household industry (10) retail and (11) economic others. We have re-classified social others into poverty grants, and summed the household industry, retail, and economic
} 


\subsection{Empirical strategy}

\subsubsection{The median voter's preferences}

In the classic median voter model, politicians implement the median voter's preferred policy, while the politician's preferences and identity are irrelevant. To test that, we estimate the following cross section model:

$$
Y_{i j}^{p}=\alpha_{1}+\alpha_{2} \text { mvoter }_{i j}^{p}+\alpha_{3} X_{i j}+\mu_{j}+\varepsilon_{i j}
$$

$Y^{p}{ }_{i j}$ are the outcome variables that represent the proportion of the UPP2 budget allocated to each program $p$ in kelurahan $i$, district $j$. Superscript $p$ stands for the eight programs as described in Table 3.1, namely: 1. roads/bridges; 2. house improvement; 3. public sanitation; 4. water and public lighting; 5. education, health, and irrigation facilities; 6. training; 7. welfare programs; and 8. microfinance. We consider the outcome variables $Y^{p}{ }_{i j}$ to be jointly determined, as they are linked by a budget constraint. Nevertheless, since the control variables are the same in all equations, estimating equation by equation using OLS estimation would produce coefficients and standard errors numerically identical to a joint estimation of the system equations. Thus, in this study, the proportion of the UPP2 budget allocated to each program $p$ is estimated equation by equation using OLS.

The effect of median voter preferences on the dependent variables is represented by a dummy variable mvoter $r_{i j}^{p}$, which takes the value of 1 if the preference of the median voter matches with the particular program type of the dependent variable. For example, in estimating the share of the budget allocated to road/bridge programs $\left(Y_{i j}^{\text {road/bridge }}\right)$, the dummy variable takes the value of 1 if the median voter in kelurahan $i$ raised this issue in their community. The median voter herself is selected based on the per capita consumption of adult individuals in the community.

Furthermore, $X_{i j}$ is a vector of controls for log population, log average consumption, and the pre-existing public goods in the kelurahan, such as access to drinkable water based on the

others into microfinance programs, since most economic projects are financed under the revolving fund scheme. 
MDG (Millennium Development Goals) definition, access to a latrine, the number of financial institutions used to save and borrow, and the distance to the nearest central bus station (in minutes). Finally, district fixed effects $\mu_{j}$ are included.

\subsubsection{The role of women representatives}

One of the implications of the median voter theorem is that the politician's identity will not matter to policy outcomes. In order to test this, we investigate the particular issue of whether higher female representation in BKM is associated with higher budget allocation to programs that are more responsive to women's needs. In the following equation, we include the variable rfemale, which represents the share of the number of female representatives in the BKM:

$$
Y_{i j}^{p}=\alpha_{1}+\alpha_{2} \text { mvoter }_{i j}^{p}+\alpha_{3} r f \text { emale }_{i j}+\alpha_{4} X_{i j}+\mu_{j}+\varepsilon_{i j}
$$

The classic median voter model predicts that the effects of rfemale will be 0 , yet, if the gender of the politician matter, $\alpha_{3} \neq 0$ that such effects might be reflected in changes in the composition of UPP2 expenditures.

Furthermore, we next examine whether female representatives are more responsive to the relative preferences of voters of their own gender. Following Chattopadhyay and Duflo (2004), we calculate the gender gap in preferences toward program $p$ as follows:

$$
D_{s i}^{p}=\left(\frac{n_{w s i}^{p}}{N_{w s i}}-\frac{n_{m s i}^{p}}{N_{m s i}}\right) \quad p=(1,2,3, \ldots, 8)
$$

Let $D_{s i}^{p}$ as the relative strength of women's preferences toward specific program $p$ in kelurahan $i$. The subscript $s$ stands for the sample used (voter or BKM representative preferences), $w$ stands for women, and $m$ for men. Therefore $n_{w s i}^{p}$ is how many times the particular program $p$ is mentioned by women, while $N_{w s i}$ is the total issues related to the UPP2 program mentioned by women. As a result, $\frac{n_{w s i}^{p}}{N_{w s i}}$ is the share of female preferences toward a particular program $p$ per total UPP2 program mentioned by women in kelurahan 
$i^{32}$ Adding $D_{s i}^{p}$ to the equation as a single and an interaction term, our empirical specification now reads:

$$
Y_{i j}^{p}=\alpha_{1}+\alpha_{2} \text { mvoter }_{i j}^{p}+\alpha_{3} \text { rfemale }_{i j}+\alpha_{4} D_{s i}^{p}+\alpha_{5}\left(\text { rfemale }_{i j} * D_{s i}^{p}\right)+X_{i j}+\mu_{j}+\varepsilon_{i j}
$$

Estimating equation (3.4), we are particularly interested in examining the interaction term between the gender gap in preferences and the share of female representation in the BKM, so that if $\alpha_{5} \neq 0$, this can be interpreted that female representatives in BKM are responsive to the relative strength of female preferences. ${ }^{33}$

To link these individual preferences into policy outcomes, our empirical strategy makes a number of assumptions. First, we assume that under perfect democracy, the project budget should be allocated proportionally to how often a preference (problem) also mentioned by residents. Second, we assume that the preferences of the residents were then communicated to the BKM members during community discussions or through project proposal submission.

\subsection{Data}

We combine two unique data sets from the World Bank, namely the UPP2 impact evaluation survey (IES) and the UPP2 monitoring information system (MIS). The IES is a built in quasi-experimental survey that was designed to evaluate the impact of UPP2. The baseline survey was conducted around February-March 2004 followed by the midterm survey that was only performed in the treatment area, carried out in 2005 for locations within Java and in March 2006 for the outer islands. The survey was conducted after the formation of BKM institution, but before the funding disbursement.

\footnotetext{
${ }^{32}$ Since the UPP2 impact evaluation survey only interviewed 3 out of 9 to 14 BKM members in every community, there are cases where none of the BKM members' preferences match any of the eight UPP2 programs. If this is the case, the nominators and the denominators of formula (3) will be equal to zero, then cause $\frac{n_{w s i}^{p}}{N_{w s i}}$ or $\frac{n_{m s i}^{p}}{N_{m s i}}$ equal to 1 , thus biasing the results. To deal with this missing data, $\frac{n_{w s i}^{p}}{N_{w s i}}$ and/or $\frac{n_{m s i}^{p}}{N_{m s i}}$ is set equal to 0 in these cases. We then create an indicator variable for kelurahans where these changes applied.

${ }^{33}$ Note that the variable $D_{s i}^{p}$ is calculated for both BKM members and voters. In the regression, we include these as different variables.
} 
For the purposes of this study, we primarily use the information from the midterm survey that captures the preferences of both BKM members and household samples in the same time frame. Indeed, using the midterm data may be biased, since it could be distorted by community expectations regarding UPP2. However, using baseline data would not capture the preferences of BKM members or the new problems that may have arisen after the survey. On top of that, we do not use the baseline survey since there is a chance that some pressing problems mentioned in the baseline survey might already have been resolved.

The second data source used in this study is the MIS data, which reports on the project's deliverables in every community. It provides information on the number of projects accomplished in every kelurahan as well as on project costs, broken down to program type (Table 3.2).

Table 3.2 Average UPP2 projects received by communities, by program type

\begin{tabular}{lcccccccc}
\hline \multirow{2}{*}{ Program } & \multicolumn{3}{c}{ Cost of projects } & \multicolumn{4}{c}{ Number of projects } \\
\cline { 2 - 9 } & Mean & Std. Dev. & Min & Max & Mean & Std. Dev. & Min & Max \\
\hline Roads/bridges & 120.2 & 62.4 & 0 & 346.7 & 22.4 & 12.3 & 0 & 58 \\
Housing & 21.7 & 29.6 & 0 & 223.2 & 4.4 & 5.9 & 0 & 34 \\
Public sanitation & 48.9 & 33.7 & 0 & 144.6 & 11.3 & 8.2 & 0 & 40 \\
Water and public lighting & 22.9 & 25.0 & 0 & 142.8 & 5.2 & 5.3 & 0 & 34 \\
Health, education and irrigation facility & 1.5 & 4.4 & 0 & 37.0 & 0.4 & 0.9 & 0 & 5 \\
Welfare programs & 52.9 & 22.7 & 13.9 & 160.8 & 9.6 & 6.8 & 3 & 44 \\
Training & 11.0 & 10.8 & 0 & 53.5 & 2.3 & 2.4 & 0 & 13 \\
Microfinance & 196.6 & 79.9 & 52.4 & 637.6 & 48.8 & 22.2 & 12 & 177 \\
\hline Notes: The calculation is based on MIS data using 154 kelurahan. Costs of the projects are in millions rupiah. & \multicolumn{3}{c}{}
\end{tabular}

Since UPP2 promotes active community participation in deciding on poverty alleviation strategies, it is expected that project resource allocation should represent the preferences of the communities. In the survey, IES randomly selected 32 households in every kelurahan to be interviewed, where in each household two representative adults (one female and one male) were asked to identify the three most urgent problems that should be improved in their community. In the questionnaire, the particular question was addressed: "Now, we are going to make inquiries concerning problems or issues that need to be improved in your kelurahan in the last one year. Name three primary issues that need problem solving or improvement in your kelurahan/village”. Three BKM members (one coordinator, one female, and one male) in every community were asked a similar question. However, although the questionnaire provides the codes for possible answers, it still fails to capture many issues, where this resulted in the code “others” being the most frequently chosen one (Pradhan et al., 2010). 
To overcome this problem, we re-classified the three open-ended responses of more than eight thousand individuals into 17 general issues, eight of which were covered by UPP2. For purposes of this study, the three preferences given by each respondent are classified by applying transitivity axioms; that is, by employing only the first-mentioned preference that matches with one of the eight programs covered by UPP2. ${ }^{34}$

Table 3.3 shows the detailed classification of the respondents' stated preferences. We differentiate between public goods provided by the central government and those covered by UPP2. For example, improvement of the quantity and quality of medical doctors falls under the domain of the central government, thus complaints related to this issue are classified under "public facilities in general”. On the other hand, complaints about bad health facilities which fall under the coverage of the UPP2 programs are classified into "education, health and irrigation facility”.

\footnotetext{
${ }^{34}$ The following rule is used: (1) if the $1^{\text {st }}$ preference matches one of the UPP2 programs, then this preference is used. (2) If the $1^{\text {st }}$ preference does not match one of the UPP2 programs, then it is replaced with the $2^{\text {nd }}$ preference, if the $2^{\text {nd }}$ rank preference matches a UPP2 program, and so on. (3) If none of the three preferences matches the UPP2 programs, then it is classified under one of the non-UPP2 issues. (4) If none of the responses matches the UPP2 programs or the non-UPP2 issues, then it is treated as a missing value.
} 
Table 3.3 Classification of open-ended preferences

\begin{tabular}{|c|c|c|}
\hline \multirow{2}{*}{$\begin{array}{l}\text { Issues covered by UPP2 Programs } \\
\text { Road/bridge improvement }\end{array}$} & \multicolumn{2}{|c|}{ Issues not covered by UPP2 Programs } \\
\hline & Agricultural issues & Others \\
\hline quality of access to the village & agricultural issues & 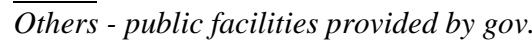 \\
\hline quality of roads within the village, talud & $\underline{\text { Education issues }}$ & public facilities in general \\
\hline House improvement & low education & health facility, poor quality of doctor \\
\hline house improvement & Environmental issues & school facility, poor quality of teacher \\
\hline Public sanitation & environmental issues & traditional market facilities \\
\hline drainage waterways facilities & pollution & bus station facilities \\
\hline sanitation & $\underline{\text { Health issues }}$ & cemetery facilities \\
\hline waste facilities & low quality of health & telecommunication facilities \\
\hline tanggul & environmental health & sport facilities \\
\hline Water and public lighting & epidemic disease & lack of worship facilities \\
\hline clean water/drinkable water & lack of community hygiene & parking facilities \\
\hline public lighting & Women's issues & village office \\
\hline Education, health and irrigation facilities & malnutrition & transportation service \\
\hline health facilities & posyandu improvement & traffic \\
\hline health facility, poor quality of building & women issues & electricity \\
\hline irrigation facilities & $\underline{\text { Poor welfare program }}$ & Others - economy in general \\
\hline school facilities, poor quality of school building & poor welfare program & economy in general \\
\hline Poverty & Security issues & welfare \\
\hline poverty & security issues & low-wage/income \\
\hline high food price & youth crime & inflation \\
\hline high health fees & Social issues & Others - service quality from local gov. \\
\hline high school fees & lack of social bonds & low service quality from gov. officer \\
\hline poverty, elderly & community cooperation & corruption \\
\hline poverty, grants & community organization & too many donations requested \\
\hline poverty, orphan & empowerment & transparency \\
\hline scholarships & participation & Others - land and natural disaster \\
\hline Training & youth issues & natural disaster \\
\hline $\overrightarrow{\text { dropping out of school }}$ & social issues & land \\
\hline lack of human resources & Unemployment & Others - individual morale \\
\hline training & unemployment & individual awareness \\
\hline Microfinance & & religion \\
\hline$\overline{\text { koperasi }}$ & & Others - others \\
\hline lack of business capital & & others, missing values, don’t know \\
\hline lack of credit facilities & & no issues, not clear \\
\hline small business support & & \\
\hline
\end{tabular}

Notes: *Posyandu is a monthly clinic for children and pregnant women, providing vaccinations and nutritional supplements. Talud is the paving on the roadside to prevent landslides. Tanggul is the embankment built to prevent flooding during the rainy season. Koperasi is a cooperative association, usually used for credit unions

Figure 3.1 presents the preferences of the median voter, who is identified using per capita consumption, regarding the eight programs offered by UPP2. Ideally, there should be 154 median voter's preferences in our sample, but since every kelurahan interviewed two adults (with the same per capita consumption) in 32 households, it can be the case that there is more than one median voter in a kelurahan. Out of 411 median voters identified in our sample, 176 of them provide suggestions that are not covered by UPP2. Figure 3.1 shows that about one-third of the median voters prefer roads/bridges improvement, followed by preferences for public sanitation and welfare programs. 
Figure 3.1 Frequency of median voter preferences, by sex

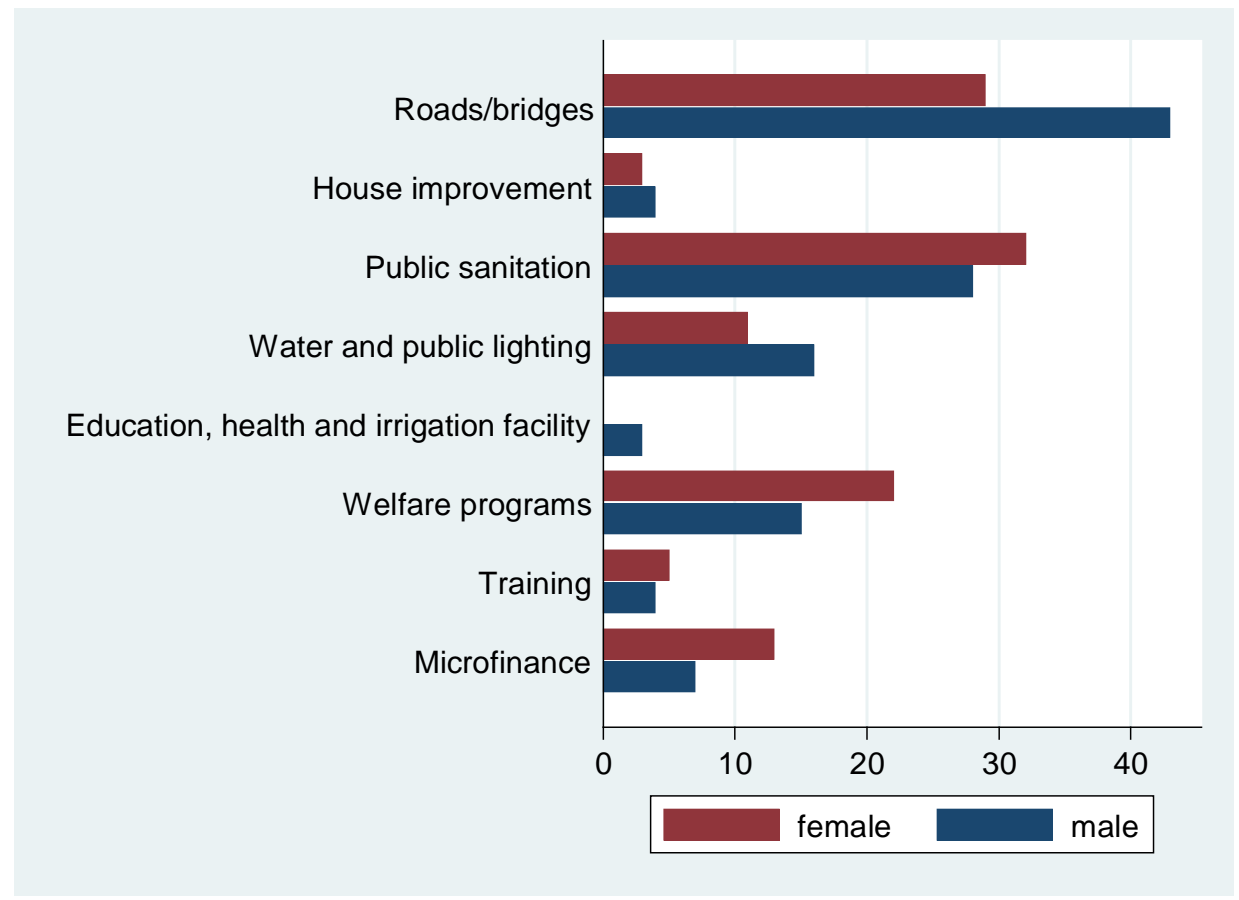

Note: The calculation is based on UPP2 impact evaluation survey and UPP2-MIS data.

We also analyze the preferences stated by voters and BKM members, grouped by gender. On average, the share of female BKM members in every kelurahan is 19 percent of the total, with the lowest share at 0 percent (for $23 \mathrm{BKM}$ ) and the highest share at around 72 percent. Table 3.4 shows the fraction of the issues mentioned by both households and BKM members broken down by gender. The table shows that the majority (more than 60 percent) of the issues mentioned by respondents correspond to the UPP2 programs. ${ }^{35}$ Focusing on the issues related to UPP2, road/bridge and public sanitation improvement are the issues that were by far the most frequently mentioned by female voters. Although male voters also promoted the same priorities, a higher proportion of men appear to prefer roads/bridges improvement. The chi-square test for whether the distributions of male and female stated preferences are the same rejects the hypothesis ( $\mathrm{p}$-value=0.001), meaning that female and male voters indeed have different preferences.

\footnotetext{
${ }^{35}$ For gender's preferences consistency check, it is interesting to see that “women's issues” is significant. That is, most women in general indeed significantly mentioned more issues that particularly very close related with women.
} 
Table 3.4 Issues raised by women and men, voters and BKM members

\begin{tabular}{|c|c|c|c|c|c|c|}
\hline \multirow[b]{3}{*}{ Poverty programs - UPP2 } & \multicolumn{3}{|c|}{ Household } & \multicolumn{3}{|c|}{ BKM } \\
\hline & \multirow{2}{*}{$\begin{array}{r}\text { Women } \\
72.2\end{array}$} & \multicolumn{2}{|c|}{ Men Diff. } & \multirow{2}{*}{$\begin{array}{r}\text { Women } \\
77.1\end{array}$} & \multirow{2}{*}{$\begin{array}{l}\text { Men } \\
68.6\end{array}$} & \multirow{2}{*}{$\begin{array}{l}\text { Diff. } \\
8.5 *\end{array}$} \\
\hline & & 71.2 & 1.0 & & & \\
\hline Agricultural issues & 0.4 & 0.7 & -0.3 & 0.0 & 0.0 & 0.0 \\
\hline Education issues & 0.5 & 0.2 & $0.3 *$ & 1.7 & 0.9 & 0.8 \\
\hline Environment and pollution & 0.4 & 0.7 & -0.2 & 0.9 & 0.9 & -0.1 \\
\hline Health issues & 2.9 & 2.1 & $0.8 * *$ & 1.7 & 2.1 & -0.4 \\
\hline Women’s issues & 0.9 & 0.1 & $0.8 * * *$ & 0.9 & 0.0 & $0.9 *$ \\
\hline Poor welfare program & 3.9 & 3.5 & 0.5 & 1.7 & 6.3 & $-4.7 * *$ \\
\hline Security issues & 2.5 & 2.5 & 0.0 & 2.5 & 1.8 & 0.7 \\
\hline Social issues & 2.5 & 2.6 & 0.0 & 1.7 & 3.3 & -1.6 \\
\hline Unemployment & 4.9 & 4.3 & 0.6 & 5.9 & 4.8 & 1.1 \\
\hline Others & 8.9 & 12.3 & $-3.4 * * *$ & 5.9 & 11.2 & -5.3 \\
\hline Total & 100 & 100 & & 100 & 100 & \\
\hline$N$ & $\underline{2,995}$ & $\underline{3,208}$ & & $\underline{118}$ & $\underline{331}$ & \\
\hline chi-square & & $\overline{52.34}$ & & & 11.61 & \\
\hline p-value & & 0.000 & & & 0.236 & \\
\hline \multicolumn{7}{|l|}{ Breakdown of UPP2 programs } \\
\hline Roads/bridges & 30.8 & 34.7 & $-3.9 * * *$ & 16.5 & 18.1 & -1.6 \\
\hline House improvement & 2.8 & 2.6 & 0.2 & 4.4 & 1.8 & 2.6 \\
\hline Public sanitation & 23.6 & 24.8 & -1.2 & 29.7 & 18.9 & $10.7 * *$ \\
\hline Water and public lighting & 9.9 & 9.4 & 0.5 & 4.4 & 9.3 & -4.9 \\
\hline Education, health, irrigation facility & 2.0 & 2.5 & -0.5 & 2.2 & 3.1 & -0.9 \\
\hline Welfare programs & 20.1 & 15.7 & $4.3 * * *$ & 24.2 & 26.4 & -2.3 \\
\hline Training & 1.9 & 2.7 & $-0.8 *$ & 5.5 & 7.5 & -2.0 \\
\hline Microfinance & 8.9 & 7.5 & $1.4 *$ & 13.2 & 15.0 & -1.8 \\
\hline Total & 100 & 100 & & 100 & 100 & \\
\hline$N$ & 2,163 & 2,284 & & 91 & 227 & \\
\hline chi-square & & 25.06 & & & 8.05 & \\
\hline$p$-value & & 0.001 & & & 0.328 & \\
\hline
\end{tabular}

In contrast, the preferences of female and male BKM members in terms of UPP2 programs seem to be similar ( $p$-value $=0.328$ ). Both groups appear to agree on the major importance of welfare programs for the poor. They tend to be different only in terms of public sanitation, as almost 30 percent of women BKM members list public sanitation as their top priority, while only 18.9 percent of male BKM members agree. If we allowed political identity to matter, we would expect that a higher share of women represented in the BKM would lead to provision of more public sanitation by UPP2, since this is the only issue on which women felt differently from their male counterparts (Table 3.5). 
Table 3.5 Descriptive statistics for general population and BKM members, by gender

\begin{tabular}{|c|c|c|c|c|c|c|}
\hline \multirow{3}{*}{ Variables } & \multicolumn{3}{|c|}{$(1)$} & \multicolumn{3}{|c|}{$(2)$} \\
\hline & \multicolumn{3}{|c|}{ BKM Members } & \multicolumn{3}{|c|}{ General Population } \\
\hline & Women & Men & & Women & Men & \\
\hline Age & 39.06 & 43.70 & $* * *$ & 41.30 & 45.46 & $* * *$ \\
\hline Married & 0.80 & 0.94 & $* * *$ & 0.90 & 0.92 & $* * *$ \\
\hline Muslim & 0.91 & 0.91 & & 0.91 & 0.90 & \\
\hline Household size & 4.49 & 4.79 & & 4.59 & 4.61 & \\
\hline \multicolumn{7}{|l|}{ Education } \\
\hline Years of schooling & 12.81 & 13.05 & $* *$ & 8.52 & 9.28 & $* * *$ \\
\hline Primary education & 0.01 & 0.02 & $* *$ & 0.41 & 0.35 & $* * *$ \\
\hline Secondary education & 0.51 & 0.40 & $* *$ & 0.20 & 0.18 & $* * *$ \\
\hline Tertiary education & 0.48 & 0.58 & $* *$ & 0.25 & 0.32 & $* * *$ \\
\hline \multicolumn{7}{|l|}{ Economic } \\
\hline Employed & 0.65 & 0.84 & $* * *$ & 0.38 & 0.87 & $* * *$ \\
\hline Working hours & 40.39 & 41.93 & & 41.84 & 45.27 & $* * *$ \\
\hline Per capita consumption & 402,264 & 392,956 & & 217,047 & 220,612 & \\
\hline \multicolumn{7}{|l|}{ Social network } \\
\hline$\overline{\text { Percentage of village officials known }}$ & 0.91 & 0.93 & & 0.64 & 0.67 & $* * *$ \\
\hline Frequency of meetings & 7.49 & 8.41 & & 4.81 & 5.32 & $* * *$ \\
\hline Number of observations & 361 & 1,558 & & 4,120 & 3,920 & \\
\hline
\end{tabular}

Interestingly, we find that the similarities of preferences between male and female BKM may be due to the similarities in their socioeconomic backgrounds. Comparing female and male BKM members (column 1), it appears that women in the BKM are as educated, as rich, and have as high levels of social networks as their male counterparts. Comparing BKM members with the overall group of adults who are eligible to run for office, it appears that particularly highly qualified people are chosen to join the BKM (column 2). ${ }^{36}$ These results are important in analyzing the effect of gender gap preferences on policy outcomes. If the preferences of female and male members of the BKM do not differ on average then there might be no effect of female representation in the BKM on policy outcomes. Thus, any effect on policy outcomes can be driven by some other related forces.

\footnotetext{
${ }^{36}$ More detailed discussion about the role of high qualified BKM members on project choice is discussed in chapter 1 .
} 


\subsection{Estimation results}

In this section, we first examine the effect of median voter preference on the shares of UPP2 budget allocation toward all programs. Subsequently, we investigate whether female representation matters for the priorities and policies made by BKM members concerning budget allocation. Finally, we further explore the issue of whether the higher number of females in the BKM will be more responsive to accommodating the relative preferences of female voters or female BKM members on allocation of UPP2 resources. Our overall results show that the effects vary with different programs.

\subsubsection{Median voter preference and female representation in BKM}

Table 3.6 presents the effect of median voter preference and female representation in the BKM on UPP2 funding allocation. The eight columns in each panel show the results of estimating the share of the budget for each of the eight programs covered by UPP2. In Panel I, we estimate UPP2 funding allocation decisions using only the median voter preference dummy variable, mvoter, which takes a value of 1 if any of the preferences of the median voter match the funding allocation toward a particular program of the dependent variable. Column 5 shows that the variable mvoter has a significant positive effect on the shares of budget allocation for education, health, and irrigation infrastructure programs, but less effect on training programs. According to the magnitude of the coefficient, it appears that the budget portion applied toward education, health, and irrigation infrastructure is 1.1 percent significantly higher in kelurahan where the median voter brought the issue forward in relation to activities covered by this program. By contrast, in kelurahan where the median voter raised the issue of the need for training activities, the budget share applied toward training programs decreases. We find this result to indicate that none of the representatives were committed to the preferences of the median voter who complains about the need for more training programs. Nevertheless, female BKM members do accommodate the preferences of this median voter more, as will be explained in the following paragraphs.

The main effect of the representative's gender on policy outcomes is captured by the inclusion of the variable rfemale, which is the proportion of BKM members who are female. The results in Panel II and Panel III show that the inclusion of rfemale neither adds further 
explanation of the results nor changes the effect of median voter preferences. This is surprising yet expected, since male and female BKM members in general have similar preferences toward different programs offered by UPP2 (as shown in Table 3.4). If women's preferences are not different from those of their male counterparts, the gender of the representative is irrelevant to shaping policy outcomes.

Interestingly, when the interaction term between rfemale and mvoter is included (Panel IV), it turns out that the coefficient of mvoter changes, while the interaction term has a positive significant effect with a larger magnitude (column 5c and column 7c). It seems that a higher share of female BKM members helps to accommodate the preferences of the median voter by allocating a higher proportion of the budget toward the programs preferred by the median voter. According to column 5c, an increase of the share of females in the BKM board membership by one standard deviation (0.14) above its mean (0.19) is associated with a 3.13 percent increase in the budget share for education, health, and irrigation projects, and a 0.85 percent increase for training programs.

\subsubsection{Female representation and the gender gap in voter preferences}

We further examine whether higher female representation in BKM is associated with greater responsiveness toward the relative preferences of female voters, although the results so far show that the fraction of women in the BKM alone does not have any effect on budget allocations. In Table 3.7, we include variable $D_{\text {voters }}^{p}$ which represents the relative strength of female voter preference toward each UPP2 program. The inclusion of this variable does not change the previous results.

In general, we find that the higher intensity of women voters' relative preferences for welfare programs (higher $D_{\text {voters }}^{p}$ ) is associated with more budget allocations to welfare programs, such as poverty grants, elderly support, scholarships, health support, etc. (column 6). This result is in accord with Table 3.4, which shows that female voters' preferences are most different from those of male voters with respect to welfare programs, while both male and female BKM members tend to agree on the importance of this program. 
In column 3, the gender gap in preferences toward public sanitation, $D_{v o t e r}^{p}$, is negative and significant while its interaction with the variable rfemale is positive and significant, with a larger magnitude. This result implies that a higher number of complaints about public sanitation from women is met with an increase in the proportion of the budget allocated to sanitation programs, but only if there is higher female-to-male ratio in the BKM. Panel II shows that this result remains consistent, even after taking out the effect of voter and mvoter*rfemale variables. This consistent result makes sense of the fact that even though the preferences of female BKM members are similar to the preferences of male BKM members, they differ most on the topic of public sanitation programs (see Table 3.4). We calculate the effect of rfemale over the range of in $D_{\text {voter }}^{\text {public sanitation }}$ in our sample, from -0.6 to 0.8 , and show the result in Figure 3.2, together with the 95 percent confidence interval.

Figure 3.2 Effect of the share of females in BKM on public sanitation budget (95\% CIs).

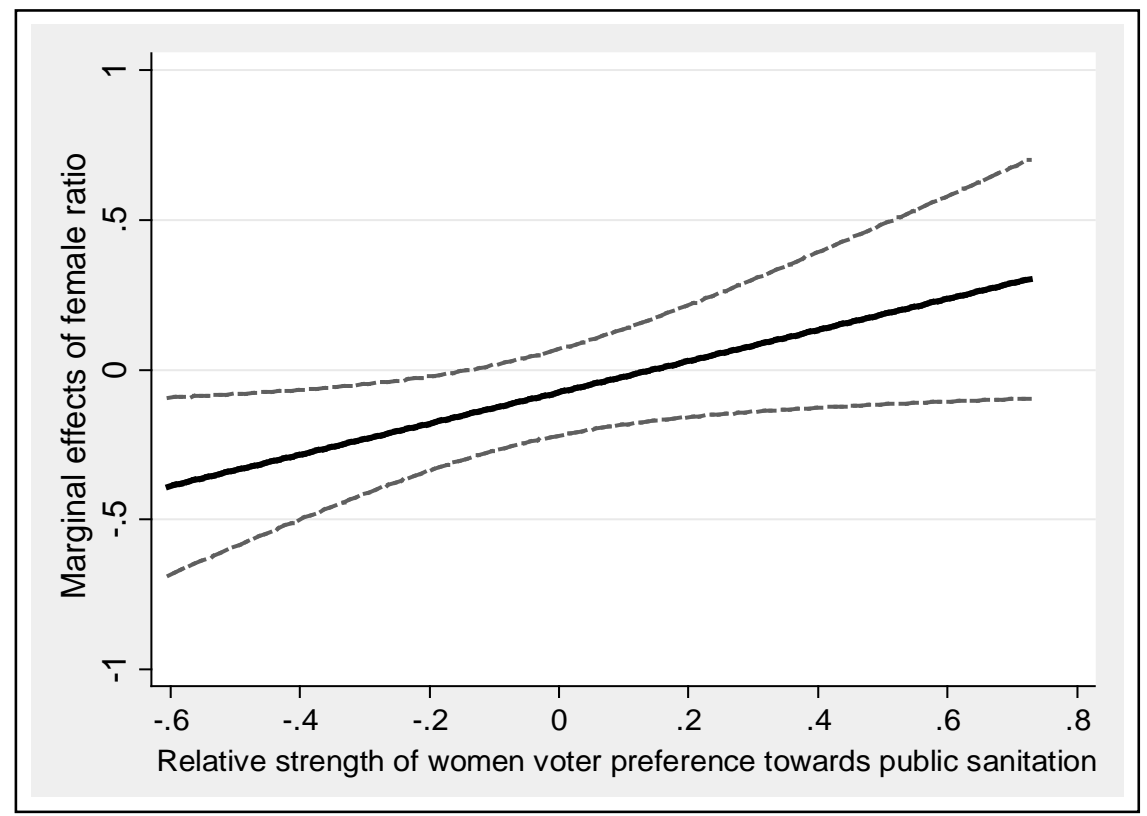

Note: The dependent variable is the proportion of UPP2 budget allocated to public sanitation programs. 
Table 3.6 The role of median voter preference and female representatives in UPP2 budget allocation

\begin{tabular}{|c|c|c|c|c|c|c|c|c|c|c|c|c|c|c|c|c|}
\hline & \multicolumn{16}{|c|}{ Dependent variable: The proportion of the budget allocated to each program } \\
\hline & \multicolumn{8}{|c|}{ PANEL I } & \multicolumn{8}{|c|}{ PANEL II } \\
\hline & $(1)$ & $(2)$ & $(3)$ & (4) & $(5)$ & $(6)$ & $(7)$ & $(8)$ & $(1 \mathrm{a})$ & $(2 a)$ & (3a) & $(4 a)$ & (5a) & $(6 a)$ & (7a) & $(8 \mathrm{a})$ \\
\hline mvoter & $\begin{array}{c}-0.014 \\
(-0.805)\end{array}$ & $\begin{array}{c}0.028 \\
(0.963)\end{array}$ & $\begin{array}{c}0.000 \\
(0.029)\end{array}$ & $\begin{array}{c}-0.010 \\
(-0.741)\end{array}$ & $\begin{array}{c}0.011^{* *} \\
(2.182)\end{array}$ & $\begin{array}{c}0.006 \\
(0.788)\end{array}$ & $\begin{array}{l}-0.008^{*} \\
(-1.928)\end{array}$ & $\begin{array}{c}-0.000 \\
(-0.006)\end{array}$ & & & & & & & & \\
\hline rfemale & & & & & & & & & $\begin{array}{c}0.086 \\
(0.893)\end{array}$ & $\begin{array}{c}0.027 \\
(0.832)\end{array}$ & $\begin{array}{c}-0.079 \\
(-1.383)\end{array}$ & $\begin{array}{c}0.028 \\
(0.713)\end{array}$ & $\begin{array}{c}-0.001 \\
(-0.172)\end{array}$ & $\begin{array}{c}-0.000 \\
(-0.013)\end{array}$ & $\begin{array}{c}-0.006 \\
(-0.466)\end{array}$ & $\begin{array}{c}-0.054 \\
(-0.672)\end{array}$ \\
\hline Number of Obs. & 153 & 153 & 153 & 153 & 153 & 153 & 153 & 153 & 153 & 153 & 153 & 153 & 153 & 153 & 153 & 153 \\
\hline Log-Likelihood & 161.34 & 283.16 & 214.65 & 282.90 & 525.24 & 321.33 & 426.84 & 188.37 & 161.65 & 282.44 & 215.85 & 282.85 & 523.93 & 320.90 & 426.11 & 188.77 \\
\hline
\end{tabular}

\begin{tabular}{|c|c|c|c|c|c|c|c|c|c|c|c|c|c|c|c|c|}
\hline & \multicolumn{16}{|c|}{ Dependent variable: The proportion of the budget allocated to each program } \\
\hline & \multicolumn{8}{|c|}{ PANEL III } & \multicolumn{8}{|c|}{ PANEL IV } \\
\hline & (1b) & (b2) & (3b) & $(4 \mathrm{~b})$ & $(5 b)$ & (6b) & (7b) & $(8 b)$ & (1c) & $(2 c)$ & (3c) & $(4 c)$ & $(5 \mathrm{c})$ & $(6 c)$ & $(7 \mathrm{c})$ & $(8 c)$ \\
\hline mvoter & $\begin{array}{c}-0.011 \\
(-0.667)\end{array}$ & $\begin{array}{c}0.027 \\
(0.938)\end{array}$ & $\begin{array}{c}0.002 \\
(0.155)\end{array}$ & $\begin{array}{c}-0.009 \\
(-0.690)\end{array}$ & $\begin{array}{c}0.011 * * \\
(2.204)\end{array}$ & $\begin{array}{c}0.006 \\
(0.806)\end{array}$ & $\begin{array}{c}-0.009 * * \\
(-2.021)\end{array}$ & $\begin{array}{c}-0.000 \\
(-0.003)\end{array}$ & $\begin{array}{c}0.006 \\
(0.204)\end{array}$ & $\begin{array}{c}0.009 \\
(0.266)\end{array}$ & $\begin{array}{c}-0.002 \\
(-0.093)\end{array}$ & $\begin{array}{c}-0.023 \\
(-1.212)\end{array}$ & $\begin{array}{c}-0.034 * * * \\
(-2.909)\end{array}$ & $\begin{array}{c}0.017 \\
(1.456)\end{array}$ & $\begin{array}{c}-0.014 * * * \\
(-3.194)\end{array}$ & $\begin{array}{c}-0.005 \\
(-0.139)\end{array}$ \\
\hline rfemale & $\begin{array}{c}0.078 \\
(0.818)\end{array}$ & $\begin{array}{c}0.024 \\
(0.725)\end{array}$ & $\begin{array}{c}-0.079 \\
(-1.393)\end{array}$ & $\begin{array}{c}0.026 \\
(0.643)\end{array}$ & $\begin{array}{c}-0.002 \\
(-0.266)\end{array}$ & $\begin{array}{c}-0.003 \\
(-0.096)\end{array}$ & $\begin{array}{c}-0.010 \\
(-0.719)\end{array}$ & $\begin{array}{c}-0.054 \\
(-0.670)\end{array}$ & $\begin{array}{c}0.106 \\
(1.097)\end{array}$ & $\begin{array}{c}0.019 \\
(0.561)\end{array}$ & $\begin{array}{c}-0.089 \\
(-1.241)\end{array}$ & $\begin{array}{c}0.017 \\
(0.413)\end{array}$ & $\begin{array}{c}-0.002 \\
(-0.215)\end{array}$ & $\begin{array}{c}0.014 \\
(0.369)\end{array}$ & $\begin{array}{c}-0.011 \\
(-0.783)\end{array}$ & $\begin{array}{c}-0.058 \\
(-0.743)\end{array}$ \\
\hline mvoter*rfemale & & & & & & & & & $\begin{array}{c}-0.094 \\
(-0.661)\end{array}$ & $\begin{array}{c}0.103 \\
(0.956)\end{array}$ & $\begin{array}{c}0.023 \\
(0.253)\end{array}$ & $\begin{array}{c}0.068 \\
(0.644)\end{array}$ & $\begin{array}{c}0.223 * * * \\
(4.031)\end{array}$ & $\begin{array}{c}-0.054 \\
(-1.417)\end{array}$ & $\begin{array}{c}0.071^{*} \\
(1.694)\end{array}$ & $\begin{array}{c}0.026 \\
(0.124)\end{array}$ \\
\hline Number of obs. & 153 & 153 & 153 & 153 & 153 & 153 & 153 & 153 & 153 & 153 & 153 & 153 & 153 & 153 & 153 & 153 \\
\hline Log-Likelihood & 161.91 & 283.42 & 215.86 & 283.21 & 525.29 & 321.34 & 427.14 & 188.77 & 162.27 & 283.96 & 215.90 & 283.61 & 526.01 & 322.11 & 427.75 & 188.79 \\
\hline
\end{tabular}

1. The proportion of the budget allocated for each program is estimated using OLS equation by equation, whereas the dependent variable is the share of UPP2 budget applied toward: (1) roads/bridges improvement, (2) house improvement, (3) public sanitation, (4) water and public lighting, (5) education, health and irrigation, (6) welfare programs, (7) training, and (8) microfinance.

2. T-values reported in parentheses are computed on the basis of heteroskedastic-robust standard errors. ${ }^{* * *} \mathrm{p}<0.01, * * \mathrm{p}<0.05, * \mathrm{p}<0.1$.

2. T-values reported in parentheses are computed on the basis of heteroskedastic-robust standard errors. ${ }^{* * *} \mathrm{p}<0.01,{ }^{* *} \mathrm{p}<0.05,{ }^{*} \mathrm{p}<0.1$.
3. The dummy variable mvoter is defined in the text: the variable takes the value of 1 if any of the median voter preferences in kelurahan $i$ match with any of the eight UPP2 programs offered.

4. The regressions control for population (log), mean per capita consumption (log), distance to the closest bus station (in minutes), share of the population with access to clean water, share of the population with

access to latrines, and the number of financial institutions used to save or borrow.

5. Districts fixed effects are included. 
Table 3.7 The role of female representatives and voter's gender gap in preferences in UPP2 budget allocation

\begin{tabular}{|c|c|c|c|c|c|c|c|c|c|c|c|c|c|c|c|c|}
\hline & \multicolumn{16}{|c|}{ Dependent variable: The proportion of the budget allocated to each program } \\
\hline & \multicolumn{8}{|c|}{ PANEL I } & \multicolumn{8}{|c|}{ PANEL II } \\
\hline & (1) & $(2)$ & (3) & (4) & (5) & (6) & (7) & (8) & (1a) & $(2 a)$ & (3a) & (4a) & $(5 a)$ & $(6 a)$ & (7a) & (8a) \\
\hline mvoter & $\begin{array}{c}0.005 \\
(0.174)\end{array}$ & $\begin{array}{c}0.007 \\
(0.202)\end{array}$ & $\begin{array}{c}-0.003 \\
(-0.117)\end{array}$ & $\begin{array}{c}-0.021 \\
(-1.071)\end{array}$ & $\begin{array}{c}-0.036 * * * \\
(-3.177)\end{array}$ & $\begin{array}{c}0.014 \\
(1.184)\end{array}$ & $\begin{array}{c}-0.015^{* * *} \\
(-2.835)\end{array}$ & $\begin{array}{c}0.006 \\
(0.179)\end{array}$ & & & & & & & & \\
\hline rfemale & $\begin{array}{c}0.110 \\
(1.103)\end{array}$ & $\begin{array}{c}0.019 \\
(0.517)\end{array}$ & $\begin{array}{c}-0.075 \\
(-1.037)\end{array}$ & $\begin{array}{c}0.015 \\
(0.340)\end{array}$ & $\begin{array}{c}-0.002 \\
(-0.251)\end{array}$ & $\begin{array}{c}0.018 \\
(0.481)\end{array}$ & $\begin{array}{c}-0.011 \\
(-0.769)\end{array}$ & $\begin{array}{c}-0.063 \\
(-0.779)\end{array}$ & $\begin{array}{c}0.093 \\
(0.933)\end{array}$ & $\begin{array}{c}0.022 \\
(0.621)\end{array}$ & $\begin{array}{c}-0.078 \\
(-1.331)\end{array}$ & $\begin{array}{c}0.023 \\
(0.572)\end{array}$ & $\begin{array}{c}-0.002 \\
(-0.193)\end{array}$ & $\begin{array}{c}0.009 \\
(0.274)\end{array}$ & $\begin{array}{c}-0.007 \\
(-0.527)\end{array}$ & $\begin{array}{c}-0.067 \\
(-0.829)\end{array}$ \\
\hline mvoter*rfemale & $\begin{array}{c}-0.086 \\
(-0.596)\end{array}$ & $\begin{array}{c}0.108 \\
(0.948)\end{array}$ & $\begin{array}{c}-0.003 \\
(-0.026)\end{array}$ & $\begin{array}{c}0.063 \\
(0.582)\end{array}$ & $\begin{array}{c}0.230 * * * \\
(4.264)\end{array}$ & $\begin{array}{c}-0.044 \\
(-1.123)\end{array}$ & $\begin{array}{c}0.072 \\
(1.599)\end{array}$ & $\begin{array}{c}-0.040 \\
(-0.185)\end{array}$ & & & & & & & & \\
\hline$D_{\text {voters }}^{p}$ & $\begin{array}{c}-0.057 \\
(-0.746)\end{array}$ & $\begin{array}{c}0.050 \\
(0.445)\end{array}$ & $\begin{array}{l}-0.110^{*} \\
(-1.799)\end{array}$ & $\begin{array}{c}-0.032 \\
(-0.613)\end{array}$ & $\begin{array}{c}-0.008 \\
(-0.495)\end{array}$ & $\begin{array}{l}0.050^{*} \\
(1.773)\end{array}$ & $\begin{array}{c}-0.006 \\
(-0.120)\end{array}$ & $\begin{array}{c}-0.044 \\
(-0.376)\end{array}$ & $\begin{array}{c}-0.063 \\
(-0.837)\end{array}$ & $\begin{array}{c}0.069 \\
(0.655)\end{array}$ & $\begin{array}{l}-0.106^{*} \\
(-1.892)\end{array}$ & $\begin{array}{c}-0.043 \\
(-0.843)\end{array}$ & $\begin{array}{c}-0.010 \\
(-0.624)\end{array}$ & $\begin{array}{c}0.058^{* *} \\
(2.094)\end{array}$ & $\begin{array}{c}0.014 \\
(0.304)\end{array}$ & $\begin{array}{c}-0.047 \\
(-0.427)\end{array}$ \\
\hline$D_{\text {voters }}^{p} *$ rfemale & $\begin{array}{c}0.288 \\
(0.793)\end{array}$ & $\begin{array}{c}-0.089 \\
(-0.206)\end{array}$ & $\begin{array}{l}0.521^{* *} \\
(2.164)\end{array}$ & $\begin{array}{c}0.033 \\
(0.123)\end{array}$ & $\begin{array}{c}0.030 \\
(0.512)\end{array}$ & $\begin{array}{c}-0.102 \\
(-0.821)\end{array}$ & $\begin{array}{c}-0.006 \\
(-0.035)\end{array}$ & $\begin{array}{c}-0.330 \\
(-0.584)\end{array}$ & $\begin{array}{c}0.318 \\
(0.866)\end{array}$ & $\begin{array}{c}-0.241 \\
(-0.654)\end{array}$ & $\begin{array}{c}0.507 * * \\
(2.331)\end{array}$ & $\begin{array}{c}0.046 \\
(0.178)\end{array}$ & $\begin{array}{c}0.024 \\
(0.415)\end{array}$ & $\begin{array}{c}-0.143 \\
(-1.204)\end{array}$ & $\begin{array}{c}-0.076 \\
(-0.462)\end{array}$ & $\begin{array}{c}-0.292 \\
(-0.581)\end{array}$ \\
\hline
\end{tabular}

Notes:

1. The proportion of the budget allocated for each program is estimated using OLS equation by equation, whereas the dependent variable is the proportion of UPP2 budget applied toward: (1) roads/bridges improvement, (2) house improvement, (3) public sanitation, (4) water and public lighting, (5) education, health and irrigation, (6) welfare programs, (7) training, and (8) microfinance.

2. T-values reported in parentheses are computed on the basis of heteroskedastic-robust standard errors. ${ }^{* * *} \mathrm{p}<0.01, * * \mathrm{p}<0.05,{ }^{*} \mathrm{p}<0.1$.

3. The dummy variable mvoter is defined in the text: the variable takes the value of 1 if any of the median voter preferences in kelurahan $i$ match with any of the eight UPP2 programs offered.

4. The variable is defined as the relative strength of female voters' preference for program $p$ in kelurahan $i$.

5. The regressions control for population (log), mean per capita consumption (log), distance to the closest bus station (in minutes), share of the population with access to clean water, share of the population with access to latrines, and the number of financial institutions used to save or borrow.

6. Districts fixed effects are included. 


\subsubsection{Female representation and the gender gap in preferences of BKM members}

In Table 3.8, we replace variable $D_{\text {voters }}^{p}$ with $D_{B K M}^{p}$, which represents the gender gap in the preferences of BKM members. Replicating the key regressions in Table 3.8, the signs and significances of the variable mvoter and mvoter*rfemale remains consistent. Focusing on variable $D_{B K M}^{p}$, (column 7 in Panel I), it can be seen that $D_{B K M}^{p}$ has a positive and significant coefficient, which indicates that funding allocation for training programs is 1.7 percent significantly higher in kelurahan where female BKM members prefer more training projects. However, the interaction term $r$ female $* D_{B K M}^{p}$ is significantly negative, which means that a higher intensity of female BKM member preferences for training programs does not necessarily translate into a higher allocation toward training programs, if the share of females in the BKM is higher. According to column 7, an increase in the share of females in the BKM for one standard deviation above its mean is associated with a decrease of budget allocations toward training programs from 7.52 percent to 7.29 percent. Thus, the effect of the differences in preferences of male and female BKM members seems not to be reflected here as much as it is in changes of composition of budget shares for public sanitation.

\subsubsection{Robustness checks}

In robustness tests, we use the number of projects instead of the costs of projects to calculate the dependent variable. Repeating the key regression, Table 3.9 shows a consistent result, although the magnitudes of the regression coefficients are smaller. In Table 3.9 column 5, it can be seen that the proportion of the budget allocated to education, health and irrigation facilities is significantly higher in kelurahan where the median voter raises the issue related to this program, although there is no effect found from the interaction variable mvoter*rfemale on budget allocation. Furthermore, Table 3.10 presents the result of the inclusion of the gender gap in the preferences of voters. Column 3 shows the robust result that a higher proportion of women in BKM accommodate the intensity of female voters' preferences on public sanitation. The interaction between $D_{v i}^{p}$ and rfemale is positive, at coefficient of 0.549 and significant at 10 percent. However, Table C3 in the appendix shows that there is no effect of the gender gap in the preferences of BKM members $D_{B K M}^{p}$ on budget allocation. 
Table 3.8 The role of BKM members' gender gap in preferences in UPP2 budget allocation

\begin{tabular}{|c|c|c|c|c|c|c|c|c|c|c|c|c|c|c|c|c|}
\hline & \multicolumn{16}{|c|}{ Dependent variable: The proportion of the budget allocated to each program } \\
\hline & \multicolumn{8}{|c|}{ PANEL I } & \multicolumn{8}{|c|}{ PANEL II } \\
\hline & (1) & $(2)$ & (3) & (4) & (5) & (6) & (7) & (8) & $(1 \mathrm{a})$ & $(2 a)$ & (3a) & $(4 a)$ & (5a) & (6a) & (7a) & $(8 a)$ \\
\hline mvoter & $\begin{array}{c}0.013 \\
(0.432)\end{array}$ & $\begin{array}{c}0.014 \\
(0.366)\end{array}$ & $\begin{array}{c}0.002 \\
(0.077)\end{array}$ & $\begin{array}{c}-0.019 \\
(-0.908)\end{array}$ & $\begin{array}{c}-0.033^{* *} \\
(-2.463)\end{array}$ & $\begin{array}{c}0.014 \\
(1.068)\end{array}$ & $\begin{array}{c}-0.017 * * * \\
(-3.268)\end{array}$ & $\begin{array}{c}-0.007 \\
(-0.205)\end{array}$ & & & & & & & & \\
\hline rfemale & $\begin{array}{c}0.075 \\
(0.758)\end{array}$ & $\begin{array}{c}0.026 \\
(0.723)\end{array}$ & $\begin{array}{c}-0.081 \\
(-1.197)\end{array}$ & $\begin{array}{c}-0.006 \\
(-0.135)\end{array}$ & $\begin{array}{c}-0.000 \\
(-0.056)\end{array}$ & $\begin{array}{c}-0.005 \\
(-0.130)\end{array}$ & $\begin{array}{c}-0.017 \\
(-1.318)\end{array}$ & $\begin{array}{c}-0.014 \\
(-0.175)\end{array}$ & $\begin{array}{c}0.045 \\
(0.442)\end{array}$ & $\begin{array}{c}0.032 \\
(0.920)\end{array}$ & $\begin{array}{c}-0.071 \\
(-1.296)\end{array}$ & $\begin{array}{c}0.003 \\
(0.055)\end{array}$ & $\begin{array}{c}-0.000 \\
(-0.022)\end{array}$ & $\begin{array}{c}-0.016 \\
(-0.453)\end{array}$ & $\begin{array}{c}-0.012 \\
(-0.909)\end{array}$ & $\begin{array}{c}-0.011 \\
(-0.134)\end{array}$ \\
\hline mvoter*rfemale & $\begin{array}{c}-0.130 \\
(-0.895)\end{array}$ & $\begin{array}{c}0.098 \\
(0.867)\end{array}$ & $\begin{array}{c}0.021 \\
(0.246)\end{array}$ & $\begin{array}{c}0.076 \\
(0.707)\end{array}$ & $\begin{array}{c}0.214 * * * \\
(3.307)\end{array}$ & $\begin{array}{c}-0.042 \\
(-0.988)\end{array}$ & $\begin{array}{l}0.080^{*} \\
(1.938)\end{array}$ & $\begin{array}{c}0.025 \\
(0.132)\end{array}$ & & & & & & & & \\
\hline$D_{B K M}^{p}$ & $\begin{array}{c}0.014 \\
(0.277)\end{array}$ & $\begin{array}{c}0.015 \\
(0.578)\end{array}$ & $\begin{array}{c}-0.014 \\
(-0.525)\end{array}$ & $\begin{array}{c}0.014 \\
(0.650)\end{array}$ & $\begin{array}{c}-0.012 \\
(-1.512)\end{array}$ & $\begin{array}{c}-0.006 \\
(-0.476)\end{array}$ & $\begin{array}{c}0.017 * * \\
(2.213)\end{array}$ & $\begin{array}{c}0.018 \\
(0.496)\end{array}$ & $\begin{array}{c}0.021 \\
(0.409)\end{array}$ & $\begin{array}{c}0.005 \\
(0.237)\end{array}$ & $\begin{array}{c}-0.014 \\
(-0.523)\end{array}$ & $\begin{array}{c}0.016 \\
(0.810)\end{array}$ & $\begin{array}{c}-0.013 \\
(-1.616)\end{array}$ & $\begin{array}{c}-0.009 \\
(-0.750)\end{array}$ & $\begin{array}{l}0.015^{* *} \\
(2.070)\end{array}$ & $\begin{array}{c}0.019 \\
(0.517)\end{array}$ \\
\hline$D_{B K M}^{p} *$ rfemale & $\begin{array}{c}-0.114 \\
(-0.518)\end{array}$ & $\begin{array}{l}-0.008 \\
(-0.076)\end{array}$ & $\begin{array}{c}0.054 \\
(0.507)\end{array}$ & $\begin{array}{c}-0.075 \\
(-0.925)\end{array}$ & $\begin{array}{c}0.048 \\
(1.375)\end{array}$ & $\begin{array}{c}0.011 \\
(0.295)\end{array}$ & $\begin{array}{l}-0.084 * \\
(-1.870)\end{array}$ & $\begin{array}{c}0.019 \\
(0.117)\end{array}$ & $\begin{array}{c}-0.154 \\
(-0.686)\end{array}$ & $\begin{array}{c}0.009 \\
(0.085)\end{array}$ & $\begin{array}{c}0.058 \\
(0.554)\end{array}$ & $\begin{array}{c}-0.077 \\
(-0.987)\end{array}$ & $\begin{array}{c}0.049 \\
(1.470)\end{array}$ & $\begin{array}{c}0.020 \\
(0.575)\end{array}$ & $\begin{array}{l}-0.077 * \\
(-1.757)\end{array}$ & $\begin{array}{c}0.014 \\
(0.080)\end{array}$ \\
\hline $\begin{array}{l}\text { Number of Obs. } \\
\text { Log-Likelihood }\end{array}$ & $\begin{array}{c}153 \\
165.47\end{array}$ & $\begin{array}{c}153 \\
284.31\end{array}$ & $\begin{array}{c}153 \\
217.98\end{array}$ & $\begin{array}{c}153 \\
285.53\end{array}$ & $\begin{array}{c}153 \\
527.01\end{array}$ & $\begin{array}{c}153 \\
324.36\end{array}$ & $\begin{array}{c}153 \\
432.42\end{array}$ & $\begin{array}{c}153 \\
192.13\end{array}$ & $\begin{array}{c}153 \\
164.57\end{array}$ & $\begin{array}{c}153 \\
282.57\end{array}$ & $\begin{array}{c}153 \\
217.84\end{array}$ & $\begin{array}{c}153 \\
284.98\end{array}$ & $\begin{array}{c}153 \\
525.16\end{array}$ & $\begin{array}{c}153 \\
323.59\end{array}$ & $\begin{array}{c}153 \\
430.13\end{array}$ & $\begin{array}{c}153 \\
192.11\end{array}$ \\
\hline
\end{tabular}

Notes:

1. The proportion of the budget allocated for each program is estimated using OLS equation by equation, whereas the dependent variable is the proportion of UPP2 budget applied toward: (1) roads/bridges improvement, (2) house improvement, (3) public sanitation, (4) water and public lighting, (5) education, health and irrigation, (6) welfare programs, (7) training, and (8) microfinance.

2. T-values reported in parentheses are computed on the basis of heteroskedastic-robust standard errors. ${ }^{* * *} \mathrm{p}<0.01,{ }^{* *} \mathrm{p}<0.05,{ }^{*} \mathrm{p}<0.1$.

3. The dummy variable mvoter is defined in the text: the variable takes the value of 1 if any of the median voter preferences in kelurahan $i$ match with any of the eight UPP2 programs offered.

4. The variable is defined as the relative strength of female voters' preference for program $p$ in kelurahan $i$.

5. The regressions control for population (log), mean per capita consumption (log), distance to the closest bus station (in minutes), share of the population with access to clean water, share of the population with access to latrines, and the number of financial institutions used to save or borrow.

6. Districts fixed effects are included. 
Table 3.9 Robustness check using alternative dependent variables, the role of the median voter and female representatives

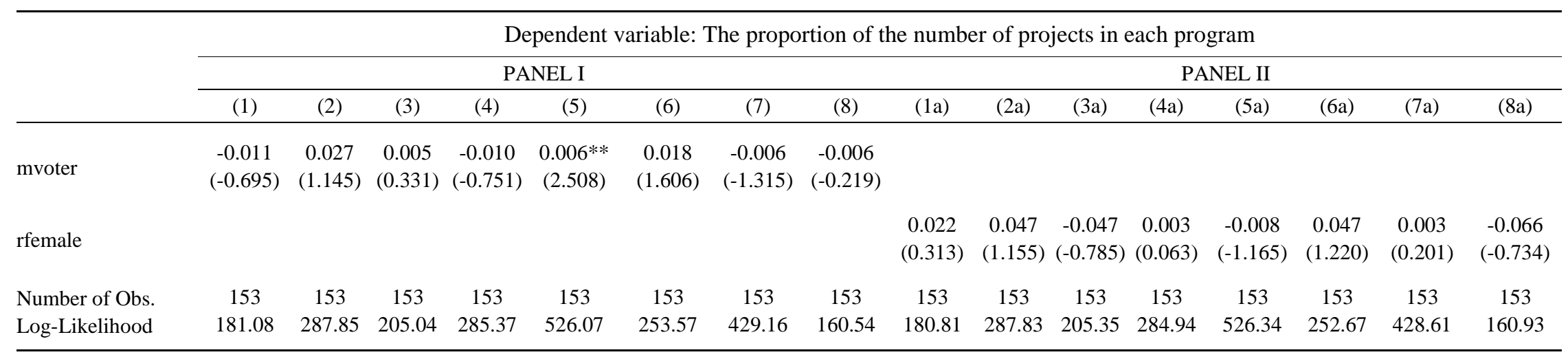

\begin{tabular}{|c|c|c|c|c|c|c|c|c|c|c|c|c|c|c|c|c|}
\hline & \multicolumn{16}{|c|}{ Dependent variable: The proportion of the number of projects in each program } \\
\hline & \multicolumn{8}{|c|}{ PANEL III } & \multicolumn{8}{|c|}{ PANEL IV } \\
\hline & $(1 \mathrm{~b})$ & (b2) & (3b) & (4b) & (5b) & $(6 b)$ & $(7 \mathrm{~b})$ & $(8 \mathrm{~b})$ & (1c) & $(2 c)$ & $(3 c)$ & $(4 \mathrm{c})$ & $(5 c)$ & $(6 c)$ & $(7 \mathrm{c})$ & $(8 c)$ \\
\hline mvoter & $\begin{array}{c}-0.011 \\
(-0.655)\end{array}$ & $\begin{array}{c}0.025 \\
(1.090)\end{array}$ & $\begin{array}{c}0.006 \\
(0.411)\end{array}$ & $\begin{array}{c}-0.010 \\
(-0.732)\end{array}$ & $\begin{array}{c}0.007 * * * \\
(2.811)\end{array}$ & $\begin{array}{c}0.017 \\
(1.484)\end{array}$ & $\begin{array}{c}-0.006 \\
(-1.284)\end{array}$ & $\begin{array}{c}-0.005 \\
(-0.220)\end{array}$ & $\begin{array}{c}0.002 \\
(0.078)\end{array}$ & $\begin{array}{c}0.022 \\
(0.710)\end{array}$ & $\begin{array}{c}0.005 \\
(0.236)\end{array}$ & $\begin{array}{c}-0.027 \\
(-1.557)\end{array}$ & $\begin{array}{c}-0.002 \\
(-0.122)\end{array}$ & $\begin{array}{c}0.025 \\
(1.560)\end{array}$ & $\begin{array}{c}-0.007 \\
(-1.120)\end{array}$ & $\begin{array}{c}0.034 \\
(1.092)\end{array}$ \\
\hline rfemale & $\begin{array}{c}0.015 \\
(0.206)\end{array}$ & $\begin{array}{c}0.043 \\
(1.062)\end{array}$ & $\begin{array}{c}-0.049 \\
(-0.819)\end{array}$ & $\begin{array}{c}0.001 \\
(0.016)\end{array}$ & $\begin{array}{c}-0.008 \\
(-1.221)\end{array}$ & $\begin{array}{c}0.039 \\
(0.965)\end{array}$ & $\begin{array}{c}0.000 \\
(0.019)\end{array}$ & $\begin{array}{c}-0.066 \\
(-0.734)\end{array}$ & $\begin{array}{c}0.035 \\
(0.484)\end{array}$ & $\begin{array}{c}0.042 \\
(1.022)\end{array}$ & $\begin{array}{c}-0.051 \\
(-0.695)\end{array}$ & $\begin{array}{c}-0.010 \\
(-0.214)\end{array}$ & $\begin{array}{c}-0.008 \\
(-1.202)\end{array}$ & $\begin{array}{c}0.051 \\
(1.069)\end{array}$ & $\begin{array}{c}0.000 \\
(0.014)\end{array}$ & $\begin{array}{c}-0.035 \\
(-0.397)\end{array}$ \\
\hline mvoter*rfemale & & & & & & & & & $\begin{array}{c}-0.069 \\
(-0.624)\end{array}$ & $\begin{array}{c}0.022 \\
(0.271)\end{array}$ & $\begin{array}{c}0.004 \\
(0.041)\end{array}$ & $\begin{array}{c}0.087 \\
(0.819)\end{array}$ & $\begin{array}{c}0.040 \\
(0.607)\end{array}$ & $\begin{array}{c}-0.039 \\
(-0.641)\end{array}$ & $\begin{array}{c}0.006 \\
(0.120)\end{array}$ & $\begin{array}{c}-0.224 \\
(-1.397)\end{array}$ \\
\hline $\begin{array}{l}\text { Number of Obs. } \\
\text { Log-Likelihood }\end{array}$ & $\begin{array}{c}153 \\
181.10\end{array}$ & $\begin{array}{c}153 \\
288.78\end{array}$ & $\begin{array}{c}153 \\
205.44\end{array}$ & $\begin{array}{c}153 \\
285.37\end{array}$ & $\begin{array}{c}153 \\
526.82\end{array}$ & $\begin{array}{c}153 \\
254.06\end{array}$ & $\begin{array}{c}153 \\
429.16\end{array}$ & $\begin{array}{c}153 \\
160.96\end{array}$ & $\begin{array}{c}153 \\
181.35\end{array}$ & $\begin{array}{c}153 \\
288.81\end{array}$ & $\begin{array}{c}153 \\
205.45\end{array}$ & $\begin{array}{c}153 \\
286.04\end{array}$ & $\begin{array}{c}153 \\
526.84\end{array}$ & $\begin{array}{c}153 \\
254.23\end{array}$ & $\begin{array}{c}153 \\
429.17\end{array}$ & $\begin{array}{c}153 \\
162.07\end{array}$ \\
\hline
\end{tabular}

1. The proportion of the number of projects in each program is estimated using OLS equation by equation, whereas the dependent variable is the share of the number of: (1) roads/bridges programs, (2) house improvement programs, (3) public sanitation programs, (4) water and public lighting programs, (5) education, health and irrigation programs, (6) welfare programs, (7) training programs, and (8) microfinance improvement programs, (3) public sanitation programs, (4) water and public lighting programs, (5) education, health and irrigation progr
programs.

2. T-values reported in parentheses are computed on the basis of heteroskedastic-robust standard errors. ${ }^{* * *} \mathrm{p}<0.01,{ }^{* *} \mathrm{p}<0.05,{ }^{*} \mathrm{p}<0.1$

3. The dummy variable mvoter is defined in the text: the variable takes the value of 1 if any of the median voter preferences in kelurahan $i$ match with any of the eight UPP2 programs offered.

4. The regressions control for population (log), mean per capita consumption (log), distance to the closest bus station (in minutes), share of the population with access to clean water, share of the population with access to latrines, and the number of financial institutions used to save or borrow.

5. Districts fixed effects are included. 
Table 3.10 Robustness check using alternative dependent variables, the role of voters' gender gap in preferences

\begin{tabular}{|c|c|c|c|c|c|c|c|c|c|c|c|c|c|c|c|c|}
\hline & \multicolumn{16}{|c|}{ Dependent variable: The proportion of the number of projects in each program } \\
\hline & \multicolumn{8}{|c|}{ PANEL I } & \multicolumn{8}{|c|}{ PANEL II } \\
\hline & (1) & $(2)$ & (3) & (4) & (5) & (6) & (7) & (8) & (1a) & $(2 a)$ & (3a) & (4a) & $(5 a)$ & $(6 a)$ & (7a) & $(8 a)$ \\
\hline mvoter & $\begin{array}{c}0.001 \\
(0.047)\end{array}$ & $\begin{array}{c}0.022 \\
(0.722)\end{array}$ & $\begin{array}{c}0.005 \\
(0.216)\end{array}$ & $\begin{array}{c}-0.028 \\
(-1.549)\end{array}$ & $\begin{array}{c}-0.004 \\
(-0.347)\end{array}$ & $\begin{array}{c}0.026 \\
(1.515)\end{array}$ & $\begin{array}{c}-0.006 \\
(-0.946)\end{array}$ & $\begin{array}{c}0.036 \\
(1.113)\end{array}$ & & & & & & & & \\
\hline rfemale & $\begin{array}{c}0.033 \\
(0.463)\end{array}$ & $\begin{array}{c}0.046 \\
(1.036)\end{array}$ & $\begin{array}{c}-0.035 \\
(-0.473)\end{array}$ & $\begin{array}{c}-0.009 \\
(-0.194)\end{array}$ & $\begin{array}{c}-0.009 \\
(-1.243)\end{array}$ & $\begin{array}{c}0.047 \\
(0.937)\end{array}$ & $\begin{array}{c}-0.001 \\
(-0.098)\end{array}$ & $\begin{array}{c}-0.042 \\
(-0.484)\end{array}$ & $\begin{array}{c}0.023 \\
(0.318)\end{array}$ & $\begin{array}{c}0.047 \\
(1.075)\end{array}$ & $\begin{array}{c}-0.046 \\
(-0.740)\end{array}$ & $\begin{array}{c}0.002 \\
(0.048)\end{array}$ & $\begin{array}{c}-0.008 \\
(-1.202)\end{array}$ & $\begin{array}{c}0.041 \\
(0.945)\end{array}$ & $\begin{array}{c}0.000 \\
(0.035)\end{array}$ & $\begin{array}{c}-0.074 \\
(-0.814)\end{array}$ \\
\hline mvoter*rfemale & $\begin{array}{c}-0.062 \\
(-0.574)\end{array}$ & $\begin{array}{c}0.029 \\
(0.341)\end{array}$ & $\begin{array}{c}-0.025 \\
(-0.225)\end{array}$ & $\begin{array}{c}0.087 \\
(0.792)\end{array}$ & $\begin{array}{c}0.052 \\
(0.808)\end{array}$ & $\begin{array}{c}-0.052 \\
(-0.776)\end{array}$ & $\begin{array}{c}0.002 \\
(0.047)\end{array}$ & $\begin{array}{l}-0.278^{*} \\
(-1.767)\end{array}$ & & & & & & & & \\
\hline$D_{\text {voters }}^{p}$ & $\begin{array}{c}-0.027 \\
(-0.472)\end{array}$ & $\begin{array}{c}-0.009 \\
(-0.093)\end{array}$ & $\begin{array}{l}-0.114^{*} \\
(-1.906)\end{array}$ & $\begin{array}{c}0.001 \\
(0.010)\end{array}$ & $\begin{array}{c}-0.016 \\
(-0.780)\end{array}$ & $\begin{array}{c}-0.000 \\
(-0.008)\end{array}$ & $\begin{array}{c}0.023 \\
(0.605)\end{array}$ & $\begin{array}{c}0.113 \\
(1.104)\end{array}$ & $\begin{array}{c}-0.032 \\
(-0.555)\end{array}$ & $\begin{array}{c}0.013 \\
(0.151)\end{array}$ & $\begin{array}{c}-0.114^{* *} \\
(-2.128)\end{array}$ & $\begin{array}{c}-0.014 \\
(-0.256)\end{array}$ & $\begin{array}{c}-0.018 \\
(-0.910)\end{array}$ & $\begin{array}{c}0.012 \\
(0.233)\end{array}$ & $\begin{array}{c}0.031 \\
(0.796)\end{array}$ & $\begin{array}{c}0.082 \\
(0.840)\end{array}$ \\
\hline$D_{\text {voters }}^{p} *$ rfemale & $\begin{array}{c}0.271 \\
(0.849)\end{array}$ & $\begin{array}{c}0.102 \\
(0.239)\end{array}$ & $\begin{array}{c}0.559 * * \\
(2.005)\end{array}$ & $\begin{array}{c}0.020 \\
(0.100)\end{array}$ & $\begin{array}{c}0.057 \\
(0.863)\end{array}$ & $\begin{array}{c}0.112 \\
(0.553)\end{array}$ & $\begin{array}{c}0.115 \\
(0.576)\end{array}$ & $\begin{array}{c}-0.717 \\
(-1.430)\end{array}$ & $\begin{array}{c}0.295 \\
(0.918)\end{array}$ & $\begin{array}{c}-0.024 \\
(-0.065)\end{array}$ & $\begin{array}{c}0.549 * * \\
(2.315)\end{array}$ & $\begin{array}{c}0.038 \\
(0.197)\end{array}$ & $\begin{array}{c}0.056 \\
(0.860)\end{array}$ & $\begin{array}{c}0.069 \\
(0.364)\end{array}$ & $\begin{array}{c}0.090 \\
(0.452)\end{array}$ & $\begin{array}{c}-0.411 \\
(-0.877)\end{array}$ \\
\hline $\begin{array}{l}\text { Number of obs. } \\
\text { Log-Likelihood }\end{array}$ & $\begin{array}{c}153 \\
181.95\end{array}$ & $\begin{array}{c}153 \\
288.87\end{array}$ & $\begin{array}{c}153 \\
207.67\end{array}$ & $\begin{array}{c}153 \\
286.05\end{array}$ & $\begin{array}{c}153 \\
527.08\end{array}$ & $\begin{array}{c}153 \\
254.63\end{array}$ & $\begin{array}{c}153 \\
430.89\end{array}$ & $\begin{array}{c}153 \\
162.88\end{array}$ & $\begin{array}{c}153 \\
181.49\end{array}$ & $\begin{array}{c}153 \\
287.84\end{array}$ & $\begin{array}{c}153 \\
207.63\end{array}$ & $\begin{array}{c}153 \\
284.97\end{array}$ & $\begin{array}{c}153 \\
526.63\end{array}$ & $\begin{array}{c}153 \\
253.14\end{array}$ & $\begin{array}{c}153 \\
430.49\end{array}$ & $\begin{array}{c}153 \\
161.23\end{array}$ \\
\hline
\end{tabular}

Notes:

1. The proportion of the number of projects in each program is estimated using OLS equation by equation, whereas the dependent variable is the share of the number of: (1) roads/bridges programs, (2) house improvement programs, (3) public sanitation programs, (4) water and public lighting programs, (5) education, health and irrigation programs, (6) welfare programs, (7) training programs, and (8) microfinance programs.

2. T-values reported in parentheses are computed on the basis of heteroskedastic-robust standard errors. ${ }^{* * *} \mathrm{p}<0.01, * * \mathrm{p}<0.05, * \mathrm{p}<0.1$.

3. The dummy variable mvoter is defined in the text: the variable takes the value of 1 if any of the median voter preferences in kelurahan $i$ match with any of the eight UPP2 programs offered.

4. The variable is defined as the relative strength of female voters' preference for program $p$ in kelurahan $i$.

5. The regressions control for population (log), mean per capita consumption (log), distance to the closest bus station (minutes), the share of the population that has access to clean water, the share of the population that has access to latrines, and the number of financial institutions used to save or borrow.

6. Districts fixed effects are included. 


\subsection{Conclusion}

Previous studies have discussed the importance of female representation in policy making for channeling women's preferences into policy outcomes. However, very few studies analyze the relevance of the differences in preferences of male and female politicians for influencing policy outcomes. In this study, we use data on ex-ante preferences of both voters and politicians in the context of UPP2, a community-driven anti-poverty development program implemented in 154 communities in Indonesia, and relate these preferences to the proportion of the budget allocated to different anti-poverty programs. We begin by testing the classic median voter theorem, which predicts that politicians will implement the median voter's preferences, and therefore politicians' identities, including categories such as gender, will not matter to outcomes. Subsequently, we test whether the movement of women into public office will affect public spending on programs that are more responsive to women's needs.

We find that in most cases, the preferences of the median voter do not matter for policy outcomes, but in some cases they do. Our findings demonstrate that the proportion of the UPP2 budget allocated to education, health and irrigation programs is higher in communities where the median voter raises the issue in relation to this particular program. We further find that the proportion of representatives who are female is not the main driver of changes in the composition of the UPP2 budget. However, a greater movement of women into local representative office does facilitate accommodating the preferences of the median voter, and particularly the preferences of female voters who request more attention to public sanitation. One possible reason for the small effect of female representatives is that the preferences of female and male representatives are similar, and that they differ only on issues related to public sanitation, but not more generally. We find that these similarities in preferences of male and female representatives may be due to the fact that both groups come from the top of the community distribution; that is, they have the same high levels of education, high consumption per capita, and high social connectedness. Still, our findings showing that the gender of the policy-maker matters for outcomes cast doubt on the prediction of the median voter theory, that only the preferences of the median voter determine public policy outcomes. 
A. Appendix to Chapter 1 
Table A1. Distribution of UPP2 projects, 2004-2007

\begin{tabular}{|c|c|c|c|c|c|c|}
\hline \multirow{2}{*}{ Project Type } & \multicolumn{2}{|c|}{ Non-revolving } & \multicolumn{2}{|c|}{ Revolving } & \multicolumn{2}{|c|}{ Total projects } \\
\hline & Number & Cost* & Number & Cost* & Number & Cost* \\
\hline \multicolumn{7}{|l|}{ Infrastructure } \\
\hline Roads/bridges & 18,626 & 130.7 & 388 & 1.8 & 19,014 & 132.5 \\
\hline Housing & 4,555 & 26.1 & 250 & 1.6 & 4,805 & 27.7 \\
\hline Public sanitation & 10,063 & 57.6 & 202 & 1.3 & 10,265 & 58.8 \\
\hline Public utilities & 6,746 & 40.2 & 87 & 0.4 & 6,833 & 40.6 \\
\hline Infrastructure - others & 1,617 & 10.0 & 27 & 0.1 & 1,644 & 10.0 \\
\hline \multicolumn{7}{|l|}{ Social } \\
\hline Social assistance & 16,134 & 82.8 & 171 & 1.1 & 16,305 & 83.9 \\
\hline Trainings & 4,531 & 23.1 & 1,300 & 2.6 & 5,831 & 25.7 \\
\hline Social-others & 843 & 4.8 & 82 & 0.5 & 925 & 5.3 \\
\hline \multicolumn{7}{|l|}{ Economic } \\
\hline Home industry & 1,278 & 7.6 & 3131 & 15.9 & 4,409 & 23.6 \\
\hline Micro retail & 565 & 4.0 & 38,719 & 185.5 & 39,284 & 189.6 \\
\hline Economic-others & 536 & 3.5 & 15,481 & 71.5 & 16,017 & 75.00 \\
\hline Total & 65,494 & 390.2 & 59,838 & 282.4 & 125,332 & 673 \\
\hline
\end{tabular}

Notes: Project costs in billion rupiah

Table A2. The construction of elite index using principal component analysis

\begin{tabular}{lrrrr}
\hline Correlations & & & & \\
\hline & Eigenvalue & Difference & Proportion & Cumulative \\
\hline Comp 1 & 1.28086 & 0.289166 & 0.427 & 0.427 \\
Comp 2 & 0.991689 & 0.264234 & 0.331 & 0.758 \\
Comp 3 & 0.727455 & & 0.243 & 1 \\
Eigenvectors & & & Comp 1 \\
\hline Variable (standardized value) & & & 0.699 \\
Per capita consumption & & & 0.694 \\
Years of schooling & & & 0.174 \\
Social network & & & \\
\hline
\end{tabular}




\section{B.Appendix to Chapter 2}


Table B1. Different estimation methods: The relationships between bribes and the time spent with officials

\begin{tabular}{|c|c|c|c|c|}
\hline \multirow[t]{2}{*}{ Independent variables } & $\begin{array}{c}\text { First } \\
\text { difference }\end{array}$ & $\begin{array}{l}\text { Fixed } \\
\text { effects }\end{array}$ & $\begin{array}{l}\text { Interval } \\
\text { regression }\end{array}$ & $\begin{array}{c}\text { Ordered } \\
\text { probit }\end{array}$ \\
\hline & $(1)$ & $(2)$ & $(3)$ & $(4)$ \\
\hline Bribes & $\begin{array}{c}0.500^{* * *} \\
(0.175)\end{array}$ & $\begin{array}{c}0.500^{* * *} \\
(0.173)\end{array}$ & $\begin{array}{c}0.422^{* * *} \\
(0.038)\end{array}$ & $\begin{array}{c}0.079 * * * \\
(0.009)\end{array}$ \\
\hline Employees & $\begin{array}{c}0.009 * * * \\
(0.003)\end{array}$ & $\begin{array}{c}0.009 * * * \\
(0.003)\end{array}$ & $\begin{array}{c}0.001^{*} \\
(0.000)\end{array}$ & $\begin{array}{c}0.000 * * \\
(0.000)\end{array}$ \\
\hline Employees squared & $\begin{array}{c}-0.000 * * * \\
(0.000)\end{array}$ & $\begin{array}{c}-0.000 * * * \\
(0.000)\end{array}$ & $\begin{array}{l}-0.000 \\
(0.000)\end{array}$ & $\begin{array}{l}-0.000 \\
(0.000)\end{array}$ \\
\hline Age & $\begin{array}{c}-0.075 \\
(0.105)\end{array}$ & $\begin{array}{c}-0.075 \\
(0.103)\end{array}$ & $\begin{array}{c}0.000 \\
(0.036)\end{array}$ & $\begin{array}{c}0.004 \\
(0.013)\end{array}$ \\
\hline Age squared & $\begin{array}{l}-0.000 \\
(0.001)\end{array}$ & $\begin{array}{l}-0.000 \\
(0.001)\end{array}$ & $\begin{array}{l}-0.000 \\
(0.001)\end{array}$ & $\begin{array}{l}-0.000 \\
(0.000)\end{array}$ \\
\hline Dummy: multinationals & $\begin{array}{c}0.192 \\
(1.284)\end{array}$ & $\begin{array}{c}0.192 \\
(1.263)\end{array}$ & $\begin{array}{l}-0.167 \\
(0.359)\end{array}$ & $\begin{array}{l}-0.035 \\
(0.105)\end{array}$ \\
\hline Dummy: has government share & $\begin{array}{c}-0.414 \\
(2.187)\end{array}$ & $\begin{array}{c}-0.414 \\
(2.152)\end{array}$ & $\begin{array}{c}1.240 \\
(1.044)\end{array}$ & $\begin{array}{c}0.439 \\
(0.283)\end{array}$ \\
\hline Dummy: if export and/or import & $\begin{array}{c}1.106 \\
(0.991)\end{array}$ & $\begin{array}{c}1.106 \\
(0.975)\end{array}$ & $\begin{array}{c}1.055^{* * *} \\
(0.397)\end{array}$ & $\begin{array}{c}0.353 * * * \\
(0.128)\end{array}$ \\
\hline /cut1 & & & & $\begin{array}{c}0.975 * * * \\
(0.300)\end{array}$ \\
\hline /cut2 & & & & $\begin{array}{c}1.863 * * * \\
(0.304)\end{array}$ \\
\hline /cut3 & & & & $\begin{array}{c}2.737 * * * \\
(0.326)\end{array}$ \\
\hline Sector fixed effects & Yes & Yes & Yes & Yes \\
\hline Region fixed effects & No & No & Yes & Yes \\
\hline Number of observations & 313 & 894 & 894 & 894 \\
\hline Adjusted R2/chi2 & 0.044 & 0.076 & 143.1 & 0.078 \\
\hline
\end{tabular}

Notes: The dependent variable is the share of managerial time spent with officials to expedite business (percent). Robust standard errors in parentheses (clustered at the firm level for first difference and FE). ${ }^{* * *} \mathrm{p}<0.01,{ }^{* *} \mathrm{p}<0.05,{ }^{*} \mathrm{p}<0.1$. 
Table B2. Bribe payments and time spent with officials, 2SLS full results

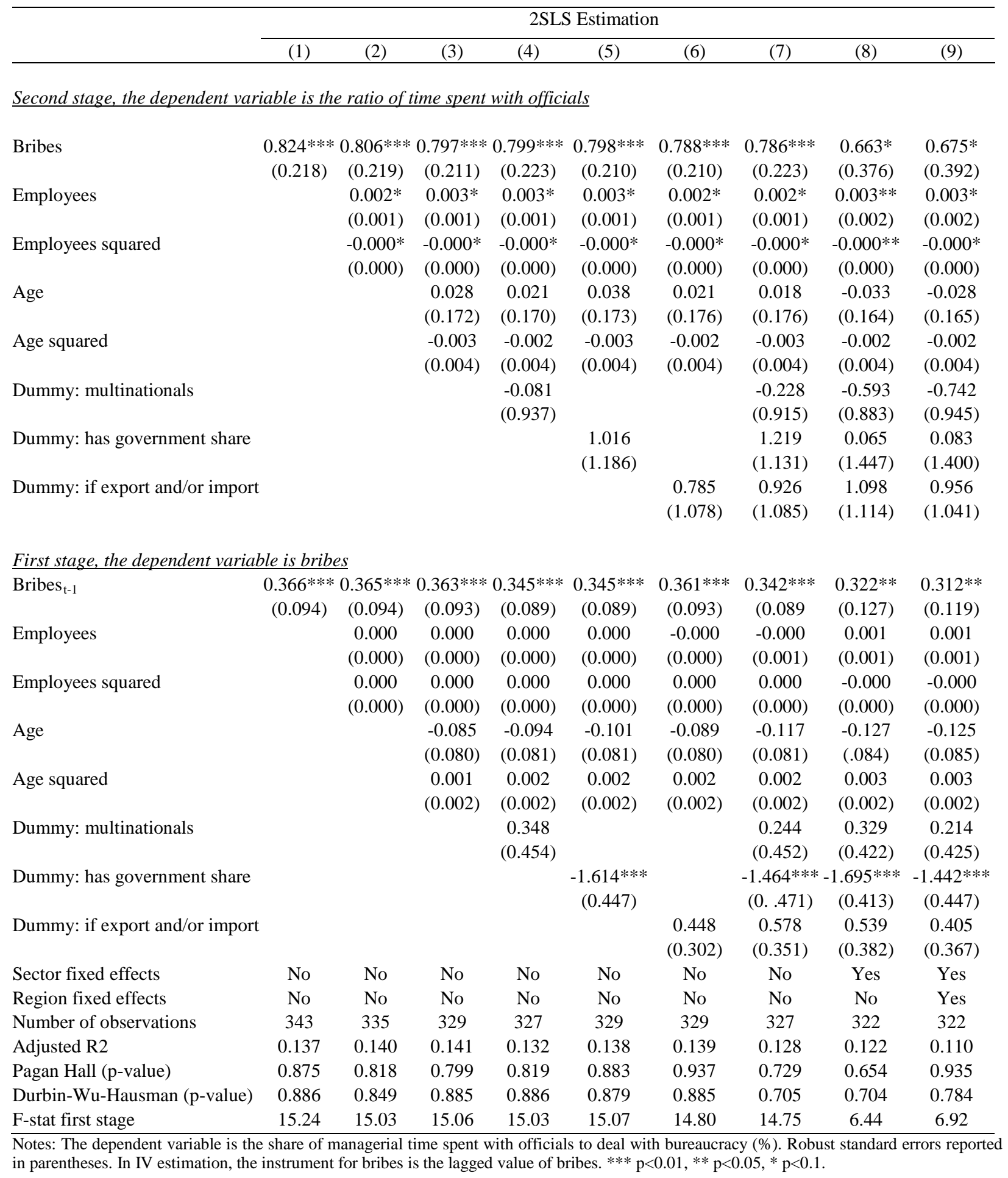


Table B3. The relationship between bribes and time spent with officials, by sector

\begin{tabular}{|c|c|c|c|}
\hline \multirow{2}{*}{$\begin{array}{l}\text { Dependent variable: the share of managerial time spent with bureaucracy } \\
\text { (percent) }\end{array}$} & \multicolumn{3}{|c|}{$\begin{array}{l}\text { Coefficient of bribes } \\
\text { (Standard errors) } \\
\text { Number of Obs. }\end{array}$} \\
\hline & $\mathrm{RE}$ & 2SLS & $\mathrm{FE}$ \\
\hline \multirow[t]{3}{*}{ All sample } & $0.497 * * *$ & $0.766^{* * *}$ & $0.365 * *$ \\
\hline & $(0.100)$ & $(0.123)$ & $(0.183)$ \\
\hline & 902 & 324 & 902 \\
\hline \multirow[t]{3}{*}{ Food, beverages and cigarette product } & $0.862 * * *$ & $1.105^{* * *}$ & $1.120 * * *$ \\
\hline & $(0.286)$ & $(0.107)$ & $(0.202)$ \\
\hline & 91 & 30 & 91 \\
\hline \multirow[t]{3}{*}{ Textile, garment, leather, footwear product } & 0.186 & 0.311 & 0.102 \\
\hline & $(0.135)$ & $(0.239)$ & $(0.123)$ \\
\hline & 226 & 86 & 226 \\
\hline \multirow[t]{3}{*}{ Wood, bamboo, and rattan product } & $0.269 *$ & $0.515^{* * *}$ & $0.598 *$ \\
\hline & $(0.158)$ & $(0.173)$ & $(0.324)$ \\
\hline & 91 & 36 & 91 \\
\hline \multirow[t]{3}{*}{ Paper, paper product, printing and publishing } & $1.593^{* * *}$ & $0.711^{* *}$ & 0.672 \\
\hline & $(0.346)$ & $(0.290)$ & (1.023) \\
\hline & 31 & 11 & 31 \\
\hline \multirow[t]{3}{*}{ Chemical product, oil \& gas, rubber and plastic } & $0.818 * * *$ & 0.587 & 0.848 \\
\hline & $(0.271)$ & $(0.670)$ & $(0.535)$ \\
\hline & 138 & 51 & 138 \\
\hline \multirow[t]{3}{*}{ Non metallic mineral product } & 0.536 & 1.329 & 0.735 \\
\hline & $(0.399)$ & (1.164) & $(0.883)$ \\
\hline & 41 & 11 & 41 \\
\hline \multirow[t]{3}{*}{ Basic metallic product } & $0.943 * *$ & $1.474 * * *$ & $1.233^{* * *}$ \\
\hline & $(0.390)$ & $(0.183)$ & $(0.172)$ \\
\hline & 85 & 31 & 85 \\
\hline \multirow[t]{3}{*}{ Non basic metallic product } & $0.469 * *$ & $0.569 * * *$ & 0.301 \\
\hline & $(0.197)$ & $(0.091)$ & $(0.311)$ \\
\hline & 173 & 59 & 173 \\
\hline
\end{tabular}


Table B4. Non-linear relationship between bribes and the time spent with officials, 2SLS full results

\begin{tabular}{|c|c|c|c|c|}
\hline & \multicolumn{4}{|c|}{ 2SLS Estimation } \\
\hline & (1) & (2) & (3) & (4) \\
\hline Bribes & $\begin{array}{c}1.413 \\
(1.035)\end{array}$ & $\begin{array}{c}1.171 \\
(0.924)\end{array}$ & $\begin{array}{c}17.615 \\
(78.908)\end{array}$ & $\begin{array}{c}6.398 \\
(12.568)\end{array}$ \\
\hline Bribes squared & $\begin{array}{l}-0.040 \\
(0.058)\end{array}$ & $\begin{array}{l}-0.029 \\
(0.052)\end{array}$ & $\begin{array}{l}-1.179 \\
(5.346)\end{array}$ & $\begin{array}{l}-0.417 \\
(0.871)\end{array}$ \\
\hline Employees & & $\begin{array}{c}0.001 \\
(0.001)\end{array}$ & $\begin{array}{l}-0.014 \\
(0.078)\end{array}$ & $\begin{array}{c}-0.003 \\
(0.011)\end{array}$ \\
\hline Employees squared & & $\begin{array}{l}-0.000 \\
(0.000)\end{array}$ & $\begin{array}{c}0.000 \\
(0.000)\end{array}$ & $\begin{array}{c}0.000 \\
(0.000)\end{array}$ \\
\hline Age & & $\begin{array}{c}0.080 \\
(0.131)\end{array}$ & $\begin{array}{c}1.431 \\
(6.729)\end{array}$ & $\begin{array}{c}0.532 \\
(1.122)\end{array}$ \\
\hline Age squared & & $\begin{array}{l}-0.004 \\
(0.003)\end{array}$ & $\begin{array}{l}-0.035 \\
(0.156)\end{array}$ & $\begin{array}{l}-0.015 \\
(0.027)\end{array}$ \\
\hline Dummy: multinationals & & $\begin{array}{l}-0.684 \\
(0.775)\end{array}$ & $\begin{array}{c}3.194 \\
(16.979)\end{array}$ & $\begin{array}{c}0.520 \\
(2.936)\end{array}$ \\
\hline Dummy: has government share & & $\begin{array}{c}1.849 \\
(1.231)\end{array}$ & $\begin{array}{c}9.537 \\
(41.008)\end{array}$ & $\begin{array}{c}4.668 \\
(8.579)\end{array}$ \\
\hline Dummy: if export and/or import & & $\begin{array}{c}1.639 * * \\
(0.718)\end{array}$ & $\begin{array}{c}6.739 \\
(24.124)\end{array}$ & $\begin{array}{c}3.118 \\
(3.666)\end{array}$ \\
\hline First staqe, the dependent variable: brib & & & & \\
\hline Bribes $_{\mathrm{t}-1}$ & $\begin{array}{c}0.664^{* * * *} \\
(0.180)\end{array}$ & $\begin{array}{c}0.603 * * * \\
(0.171)\end{array}$ & $\begin{array}{c}0.783^{* * *} \\
(0.174)\end{array}$ & $\begin{array}{c}0.735^{* * *} \\
(0.157)\end{array}$ \\
\hline Bribes $_{\mathrm{t}-1}$ squared & $\begin{array}{l}-0.01^{*} \\
(0.005)\end{array}$ & $\begin{array}{l}-0.008 \\
(0.005)\end{array}$ & $\begin{array}{c}-0.018^{* * *} \\
(0.005)\end{array}$ & $\begin{array}{c}-0.016 * * * \\
(0.005)\end{array}$ \\
\hline Employees & & $\begin{array}{c}0.000 \\
(0.001)\end{array}$ & $\begin{array}{c}0.000 \\
(0.001)\end{array}$ & $\begin{array}{c}0.000 \\
(0.001)\end{array}$ \\
\hline Employees squared & & $\begin{array}{c}0.000 \\
(0.000)\end{array}$ & $\begin{array}{c}0.000 \\
(0.000)\end{array}$ & $\begin{array}{c}0.000 \\
(0.000)\end{array}$ \\
\hline Age & & $\begin{array}{c}-0.128 \\
(0.081)\end{array}$ & $\begin{array}{l}-0.125 \\
(0.082)\end{array}$ & $\begin{array}{c}-0.126 \\
(0.082)\end{array}$ \\
\hline Age squared & & $\begin{array}{c}0.003 \\
(0.002)\end{array}$ & $\begin{array}{c}0.003 \\
(0.002)\end{array}$ & $\begin{array}{c}0.003 \\
(0.002)\end{array}$ \\
\hline Dummy: multinationals & & $\begin{array}{c}0.350 \\
(0.445)\end{array}$ & $\begin{array}{c}0.336 \\
(0.422)\end{array}$ & $\begin{array}{c}0.289 \\
(0.428)\end{array}$ \\
\hline Dummy: has government share & & $\begin{array}{c}-1.495^{* *} \\
(0.627)\end{array}$ & $\begin{array}{c}-1.763^{* * *} \\
(0.659)\end{array}$ & $\begin{array}{c}-1.485^{* *} \\
(0.653)\end{array}$ \\
\hline Dummy: if export and/or import & & $\begin{array}{l}0.617^{*} \\
(0.339\end{array}$ & $\begin{array}{c}0.564 * * * * \\
(0.358)\end{array}$ & $\begin{array}{c}0.479 \\
(0.358)\end{array}$ \\
\hline$\Pi^{*}$ & $\begin{array}{c}10.71 \\
(0.000)\end{array}$ & $\begin{array}{l}10.07 \\
(0.000)\end{array}$ & $\begin{array}{c}10.81 \\
(0.000)\end{array}$ & $\begin{array}{c}12.09 \\
(0.000)\end{array}$ \\
\hline First stage, the dependent variable: brib & & & & \\
\hline Bribes $_{\mathrm{t}-1}$ & $\begin{array}{l}9.170 * * \\
(4.182)\end{array}$ & $\begin{array}{c}7.885^{* *} \\
(4.040)\end{array}$ & $\begin{array}{c}11.160 * * \\
(4.385)\end{array}$ & $\begin{array}{c}9.938 * * * \\
(3.564)\end{array}$ \\
\hline Bribes $_{\mathrm{t}-1}$ squared & $\begin{array}{l}-0.086 \\
(0.116)\end{array}$ & $\begin{array}{l}-0.060 \\
(0.111)\end{array}$ & $\begin{array}{c}-0.253^{* * *} \\
(0.127)\end{array}$ & $\begin{array}{c}-0.213^{* * *} \\
(0.109)\end{array}$ \\
\hline Employees & & $\begin{array}{l}-0.014 \\
(0.010)\end{array}$ & $\begin{array}{c}-0.011 \\
(0.011)\end{array}$ & $\begin{array}{c}-0.007 \\
(0.010)\end{array}$ \\
\hline Employees squared & & $\begin{array}{l}0.000 \\
(0.000)\end{array}$ & $\begin{array}{c}0.000 \\
(0.000)\end{array}$ & $\begin{array}{c}0.000 \\
(0.000)\end{array}$ \\
\hline Age & & $\begin{array}{l}-0.808 \\
(1.555)\end{array}$ & $\begin{array}{l}-0.626 \\
(1.609)\end{array}$ & $\begin{array}{c}-0.606 \\
(1.667)\end{array}$ \\
\hline Age squared & & $\begin{array}{c}0.013 \\
(0.034)\end{array}$ & $\begin{array}{c}0.011 \\
(0.035)\end{array}$ & $\begin{array}{c}0.008 \\
(0.038)\end{array}$ \\
\hline Dummy: multinationals & & $\begin{array}{c}8.723 \\
(9.166)\end{array}$ & $\begin{array}{c}8.120 \\
(7.542)\end{array}$ & $\begin{array}{l}7.080 \\
(7.716)\end{array}$ \\
\hline Dummy: has government share & & $\begin{array}{l}-12.647 \\
(9.309)\end{array}$ & $\begin{array}{c}-18.131^{*} \\
(9.883)\end{array}$ & $\begin{array}{c}-11.850 \\
(10.498)\end{array}$ \\
\hline Dummy: if export and/or import & & $\begin{array}{c}12.082^{* *} \\
(5.963)\end{array}$ & $\begin{array}{l}12.304 * \\
(7.169)\end{array}$ & $\begin{array}{l}10.133 \\
(6.541)\end{array}$ \\
\hline F-stat & 5.81 & 5.41 & 4.38 & 5.37 \\
\hline Sector fixed effects/region fixed effects & no/no & no/no & yes/no & yes/yes \\
\hline Number of observations & 340 & 324 & 319 & 319 \\
\hline Adjusted R2 & 0.147 & 0.163 & -36.100 & -4.869 \\
\hline
\end{tabular}




\section{Appendix to Chapter 3}


Table C1. Descriptive statistics

\begin{tabular}{|c|c|c|c|c|}
\hline Variable & Mean & Std. & Min & Max \\
\hline Share of females in BKM & 0.19 & 0.14 & 0 & 0.73 \\
\hline Population & 5,821 & 3,817 & 549 & 25,733 \\
\hline Per capita consumption (in rupiah) & 212,733 & 138,808 & 62,941 & 874,886 \\
\hline Access to adequate water (according to the MDG definition) & 0.8 & 0.2 & 0 & 1 \\
\hline Access to latrine & 0.7 & 0.2 & 0 & 1 \\
\hline Distance to the nearest central bus station (in minutes) & 14.9 & 13.3 & 0 & 90 \\
\hline Number of financial institutions used to save/borrow & 3.08 & 1.6 & 0 & 9 \\
\hline
\end{tabular}

Note: Calculated based on 154 kelurahans

Table C2. Women's participation in UPP2

BKM institution

Number of BKMs formed

2,059 unit

Number of BKM members elected

Number of woman BKM members elected

25,537 person

16.34 percent

Election of BKM's members

Number of adult voters in kelurahan

Average adult voters in kelurahan

Average female adult voters in kelurahan

3,114,763 person

64.98 percent

48.60 percent

Participation of women

Woman facilitator

Woman participated during initial socialization to total participant

22.75 percent

30.07 percent

Woman participated in FGD to total participant

39.36 percent

Woman participated in CDP preparation to total participant

32.82 percent

Note: Calculated from the UPP2 -MIS data using 2,059 UPP2 kelurahan. 
Table C3. Robustness check, using alternative dependent variables, the role of BKM members’ preferences

\begin{tabular}{|c|c|c|c|c|c|c|c|c|c|c|c|c|c|c|c|c|}
\hline \multirow{3}{*}{$\begin{array}{l}\text { Independent } \\
\text { variables }\end{array}$} & \multicolumn{16}{|c|}{ Dependent variable: The proportion of the number of projects in each program } \\
\hline & \multicolumn{8}{|c|}{ PANEL I } & \multicolumn{8}{|c|}{ PANEL II } \\
\hline & $(1)$ & $(2)$ & (3) & (4) & $(5)$ & $(6)$ & $(7)$ & $(8)$ & $(1 \mathrm{a})$ & $(2 \mathrm{a})$ & (3a) & $(4 a)$ & $(5 a)$ & $(6 a)$ & $(7 a)$ & (8a) \\
\hline mvoter & $\begin{array}{c}-0.001 \\
(-0.046)\end{array}$ & $\begin{array}{c}0.029 \\
(0.857)\end{array}$ & $\begin{array}{c}0.007 \\
(0.326)\end{array}$ & $\begin{array}{c}-0.020 \\
(-1.077)\end{array}$ & $\begin{array}{c}0.002 \\
(0.141)\end{array}$ & $\begin{array}{c}0.020 \\
(1.257)\end{array}$ & $\begin{array}{c}-0.008 \\
(-1.288)\end{array}$ & $\begin{array}{c}0.045 \\
(1.283)\end{array}$ & & & & & & & & \\
\hline rfemale & $\begin{array}{c}0.013 \\
(0.195)\end{array}$ & $\begin{array}{c}0.047 \\
(1.154)\end{array}$ & $\begin{array}{c}-0.051 \\
(-0.713)\end{array}$ & $\begin{array}{c}-0.047 \\
(-0.855)\end{array}$ & $\begin{array}{c}-0.005 \\
(-0.711)\end{array}$ & $\begin{array}{c}0.020 \\
(0.409)\end{array}$ & $\begin{array}{c}-0.006 \\
(-0.408)\end{array}$ & $\begin{array}{c}-0.000 \\
(-0.001)\end{array}$ & $\begin{array}{c}0.006 \\
(0.094)\end{array}$ & $\begin{array}{c}0.048 \\
(1.220)\end{array}$ & $\begin{array}{c}-0.048 \\
(-0.804)\end{array}$ & $\begin{array}{c}-0.037 \\
(-0.709)\end{array}$ & $\begin{array}{c}-0.004 \\
(-0.671)\end{array}$ & $\begin{array}{c}0.018 \\
(0.445)\end{array}$ & $\begin{array}{c}-0.003 \\
(-0.205)\end{array}$ & $\begin{array}{c}-0.037 \\
(-0.428)\end{array}$ \\
\hline mvoter*rfemale & $\begin{array}{c}-0.052 \\
(-0.478)\end{array}$ & $\begin{array}{c}0.003 \\
(0.038)\end{array}$ & $\begin{array}{c}0.003 \\
(0.037)\end{array}$ & $\begin{array}{c}0.081 \\
(0.750)\end{array}$ & $\begin{array}{c}0.018 \\
(0.244)\end{array}$ & $\begin{array}{c}-0.025 \\
(-0.395)\end{array}$ & $\begin{array}{c}0.008 \\
(0.175)\end{array}$ & $\begin{array}{c}-0.279 \\
(-1.612)\end{array}$ & & & & & & & & \\
\hline$D_{B K M}^{p}$ & $\begin{array}{c}0.051 \\
(1.161)\end{array}$ & $\begin{array}{c}0.048 \\
(1.219)\end{array}$ & $\begin{array}{c}-0.013 \\
(-0.499)\end{array}$ & $\begin{array}{c}0.029 \\
(1.519)\end{array}$ & $\begin{array}{c}-0.027 \\
(-1.569)\end{array}$ & $\begin{array}{c}-0.008 \\
(-0.536)\end{array}$ & $\begin{array}{l}0.015^{*} \\
(1.893)\end{array}$ & $\begin{array}{c}0.056 \\
(1.481)\end{array}$ & $\begin{array}{c}0.052 \\
(1.190)\end{array}$ & $\begin{array}{c}0.032 \\
(0.888)\end{array}$ & $\begin{array}{c}-0.013 \\
(-0.479)\end{array}$ & $\begin{array}{l}0.032 * \\
(1.727)\end{array}$ & $\begin{array}{c}-0.027 \\
(-1.593)\end{array}$ & $\begin{array}{c}-0.010 \\
(-0.742)\end{array}$ & $\begin{array}{c}0.013 * \\
(1.781)\end{array}$ & $\begin{array}{c}0.044 \\
(1.026)\end{array}$ \\
\hline$D_{B K M}^{p} *$ rfemale & $\begin{array}{c}-0.228 \\
(-0.996)\end{array}$ & $\begin{array}{c}-0.180 \\
(-1.052)\end{array}$ & $\begin{array}{c}0.061 \\
(0.590)\end{array}$ & $\begin{array}{c}-0.103 \\
(-1.570)\end{array}$ & $\begin{array}{c}0.097 \\
(1.560)\end{array}$ & $\begin{array}{c}-0.000 \\
(-0.002)\end{array}$ & $\begin{array}{c}-0.058 \\
(-1.356)\end{array}$ & $\begin{array}{c}-0.245 \\
(-1.207)\end{array}$ & $\begin{array}{c}-0.240 \\
(-1.025)\end{array}$ & $\begin{array}{c}-0.144 \\
(-0.861)\end{array}$ & $\begin{array}{c}0.064 \\
(0.632)\end{array}$ & $\begin{array}{l}-0.105^{*} \\
(-1.697)\end{array}$ & $\begin{array}{c}0.097 \\
(1.583)\end{array}$ & $\begin{array}{c}0.003 \\
(0.073)\end{array}$ & $\begin{array}{c}-0.055 \\
(-1.296)\end{array}$ & $\begin{array}{c}-0.169 \\
(-0.670)\end{array}$ \\
\hline Number of obs. & 153 & 153 & 153 & 153 & 153 & 153 & 153 & 153 & 153 & 153 & 153 & 153 & 153 & 153 & 153 & 153 \\
\hline Log-Likelihood & 185.39 & 289.63 & 206.41 & 289.18 & 532.05 & 256.60 & 430.99 & 165.52 & 184.96 & 288.41 & 206.24 & 288.54 & 531.67 & 255.35 & 430.22 & 163.82 \\
\hline
\end{tabular}

Notes:

1. The proportion of the number of projects in each program is estimated using OLS equation by equation, whereas the dependent variable is the share of the number of: (1) roads/bridges programs, (2) house improvement programs, (3) public sanitation programs, (4) water and public lighting programs, (5) education, health and irrigation programs, (6) welfare programs, (7) training programs, and (8) microfinance programs.

2. T-values reported in parentheses are computed on the basis of heteroskedastic-robust standard errors. *** $p<0.01, * * p<0.05, * p<0.1$.

3. The dummy variable mvoter is defined in the text: the variable takes the value of 1 if any of the median voter preferences in kelurahan $i$ match with any of the eight UPP2 programs offered.

4. The variable is defined as the relative strength of female voters' preference for program $p$ in kelurahan $i$.

5. The regressions control for population (log), mean per capita consumption (log), distance to the closest bus station (in minutes), share of the population with access to clean water, share of the population with access to latrines, and the number of financial institution used to save or borrow.

6. Districts fixed effects are included. 


\section{Bibiliography}

Acemoglu, Daron, and James A. Robinson. "Persistence of Power, Elites, and Institutions." American Economic Review 98, no. 1 (2008): 267-93.

Agarwal, Bina. "Participatory Exclusions, Community Forestry, and Gender: An Analysis for South Asia and a Conceptual Framework." World Development 29, no. 10 (October 2001): 1623-1648.

Alesina, Alberto, and Eliana La Ferrara. "Participation in Heterogeneous Communities.” The Quarterly Journal of Economics 115, no. 3 (2000): 847-904.

Andvig, Jens Christopher. “The Economics of Corruption: A Survey,” Studi Economici, 1991, 43, pp. 57-94.

Aranoff, D. and Tedeschi, J. T. "Original Stakes and Behavior in the Prisoner's Dilemma game.” Psychonomic Science 12 (1968): 79-80.

Araujo, M. Caridad, Francisco H. G. Ferreira, Peter Lanjouw, and Berk Özler. "Local Inequality and Project Choice: Theory and Evidence from Ecuador.” Journal of Public Economics 92, no. 5-6 (2008): 1022-1046.

Arellano, M. "On the Testing of Correlated Effects with Panel Data." Journal of Econometrics, 59, (1993): 87-97.

Asian Development Bank, “Indonesia Country Gender Assessment.” The Asia Foundation, Asian Development Bank, Canadian International Development Agency, National Democratic Institute, The World Bank . 2006.

Babcock, Linda, and Sara Laschever. Women Don't Ask: Negotiation and the Gender Divide. Princeton University Press, 2009.

Baland, Jean-Marie, and Jean-Philippe Platteau. "Wealth Inequality and Efficiency in the Commons: Part I: The Unregulated Case.” Oxford Economic Papers 49, no. 4 (1997): 451-82.

Bardhan, Pranab. "Decentralization of Governance and Development.” Journal of Economic Perspectives 16, no. 4 (December 2002): 185-205.

Pranab. "Corruption and Development: A Review of Issues." Journal of Economic Literature 35, no. 3 (September 1, 1997): 1320-46. 
Pranab. "Irrigation and Cooperation: An Empirical Analysis of 48 Irrigation Communities in South India.” Economic Development and Cultural Change 48, no. 4 (2000): 847-65.

Bardhan, Pranab K., and Dilip Mookherjee. "Capture and Governance at Local and National Levels.” American Economic Review 90, no. 2 (2000): 135-139.

"Decentralisation and Accountability in Infrastructure Delivery in Developing Countries*.” The Economic Journal 116, no. 508 (2006): 101-27.

Basri, Muhammad Chatib. "Economic Update 2003 After Five Years Reformasi Ekonomi, What Next?” In Business in Indonesia: New Challenges, Old Problems. - Singapore : ISEAS, P. 39-57, 2004.

Beaman, Lori, Raghabendra Chattopadhyay, Esther Duflo, Rohini Pande, and Petia Topalova. "Powerful Women: Does Exposure Reduce Bias?" The Quarterly Journal of Economics 124, no. 4 (2009): 1497-1540.

Beard, Victoria A., and Aniruddha Dasgupta. "Collective Action and Community-Driven Development in Rural and Urban Indonesia.” Urban Studies 43, no. 9 (August 1, 2006): 1451-1468.

Beard, Victoria A., Faranak Miraftab, and Christopher Silver, eds. Planning and Decentralization: Contested Spaces for Public Action in the Global South: Contested Space for Public Action in the Global South. 1st ed. Routledge, 2008.

Beck, Paul J. and Maher, Michael W. "A Comparison of Bribery and Bidding in Thin Markets,” Econ.Letters, 1986, 20: 1-5.

Ben-Ner, Avner, Fanmin Kong, and Louis Putterman. "Share and Share Alike? GenderPairing, Personality, and Cognitive Ability as Determinants of Giving." Journal of Economic Psychology 25, no. 5 (2004): 581-89.

Besley, Timothy, and Stephen Coate. "An Economic Model of Representative Democracy.” The Quarterly Journal of Economics 112, no. 1 (February 1, 1997): 85-114.

Bliss, Christopher, and Rafael Di Tella. "Does Competition Kill Corruption?” Journal of Political Economy 105, no. 5 (October 1, 1997): 1001-23.

Bhalotra, Sonia, and Irma Clots-Figueras. Health and the Political Agency of Women. Economics Discussion Paper. University of Essex, Department of Economics, 2013. 
Buss, David M. Evolutionary Psychology: The New Science of the Mind. Boston: Pearson Allyn \& Bacon, 2012.

Chattopadhyay, Raghabendra, and Esther Duflo. "Women as Policy Makers: Evidence from a Randomized Policy Experiment in India.” Econometrica 72, no. 5 (2004): 1409-1443.

Clark, Derek J., and Christian Riis. “Allocation Efficiency in a Competitive Bribery Game.” Journal of Economic Behavior \& Organization 42, no. 1 (2000): 109-24.

Conning, Jonathan, and Michael Kevane. "Community-Based Targeting Mechanisms for Social Safety Nets: A Critical Review.” World Development 30, no. 3 (2002): 375394.

Dasgupta, Aniruddha, and Victoria A. Beard. "Community Driven Development, Collective Action and Elite Capture in Indonesia.” Development and Change 38, no. 2 (2007): 229-249.

Dayton-Johnson, Jeff, and Pranab Bardhan. "Inequality And Conservation On The Local Commons: A Theoretical Exercise.” Economic Journal 112, no. 481 (2002): 577-602.

Downs, Anthony. An Economic Theory of Democracy. Harper, 1957.

Duflo, Esther. "Why Political Reservations?” Journal of the European Economic Association 3, no. 2-3 (2005): 668-678.

Duflo, Esther. "Women Empowerment and Economic Development." Journal of Economic Literature 50, no. 4 (December 2012): 1051-79.

Eckel, Catherine C., and Philip J. Grossman. “Are Women Less Selfish Than Men? Evidence from Dictator Experiments.” Economic Journal 108, no. 448 (1998): 726-35.

Edlund, Lena, and Rohini Pande. "Why Have Women Become Left-Wing? The Political Gender Gap and the Decline in Marriage.” The Quarterly Journal of Economics 117, no. 3 (2002): 917-961.

Fafchamps, Marcel, David McKenzie, David McKenzie, Simon Quinn, and Christopher Woodruff. When Is Capital Enough to Get Female Enterprises GrowingEvidence from a Randomized Experiment in Ghana. Policy Research Working Paper Series. The World Bank, 2011.

Fisman, Raymond, and Roberta Gatti. Bargaining for Bribes: The Role of Institutions. CEPR Discussion Paper. C.E.P.R. Discussion Papers, 2006. 
- "Decentralization and Corruption: Evidence across Countries." Journal of Public Economics 83, no. 3 (2002): 325-45.

Foster, Andrew D., and Mark R. Rosenzweig. "Democratization, Decentralization and the Distribution of Local Public Goods in a Poor Rural Economy.” SSRN eLibrary (November 2001).

Fransisco, Manuela, and Nicola Pontara. Does Corruption Impact On Firms' Ability To Conduct Business In Mauritania? Evidence From Investm ent Climate Survey Data. Policy Research Working Papers. The World Bank, 2008.

Funk, Patricia, and Christina Gathmann. "What Women Want: Suffrage, Gender Gaps in Voter Preferences and Government Expenditures.” SSRN Scholarly Paper (2006).

Galasso, Emanuela, and Martin Ravallion. "Decentralized Targeting of an Antipoverty Program.” Journal of Public Economics 89, no. 4 (2005): 705-727.

Gneezy, Uri, Muriel Niederle, and Aldo Rustichini. "Performance in Competitive Environments: Gender Differences.” The Quarterly Journal of Economics 118, no. 3 (August 1, 2003): 1049-74.

Guriev, Sergei. "Red Tape and Corruption.” Journal of Development Economics 73, no. 2 (2004): 489-504.

Henderson, J. Vernon, and Ari Kuncoro. "Corruption and Local Democratization in Indonesia: The Role of Islamic Parties.” Journal of Development Economics 94, no. 2 (2011): 164-80.

Corruption in Indonesia. Working Paper. National Bureau of Economic Research, August 2004.

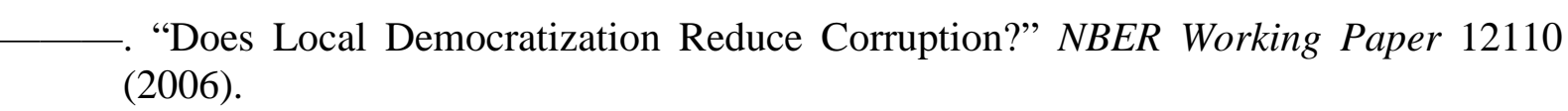

Hill, Hal. The Indonesian Economy. 2 edition. Cambridge, UłKNew York: Cambridge University Press, 2000.

Hunt, Jennifer. Why Are Some Public Officials More Corrupt Than Others? CEPR Discussion Papers, 2005.

Hunt, Jennifer, and Sonia Laszlo. Bribery: Who Pays, Who Refuses, What Are the Payoffs? NBER Working Paper, 2005. 
Huntington, Samuel P. Political Order in Changing Societies. New Haven: Yale University Press, 1968.

Johnson, Simon, Daniel Kaufmann, John McMillan, and Christopher Woodruff. "Why Do Firms Hide? Bribes and Unofficial Activity after Communism." Journal of Public Economics 76, no. 3 (2000): 495-520.

John R. Lott, Jr., and Lawrence W. Kenny. "Did Women's Suffrage Change the Size and Scope of Government?” Journal of Political Economy 107, no. 6 (December 1, 1999): 1163-1198.

Karlan, Dean, and Jonathan Zinman. "Microcredit in Theory and Practice: Using Randomized Credit Scoring for Impact Evaluation.” Science 332, no. 6035 (June 10, 2011): 127884.

Kaufmann, Daniel, and Shang-Jin Wei. Does “Grease Money" Speed Up the Wheels of Commerce? NBER Working Paper. National Bureau of Economic Research, Inc, 1999.

Khwaja, Asim Ijaz. “Can Good Projects Succeed in Bad Communities?” Journal of Public Economics 93, no. 7-8 (2009): 899-916.

Kuncoro, Ari. "Corruption and Business Uncertainty in Indonesia." ASEAN Economic Bulletin 23, no. 1 (April 2006): 11-30.

La Ferrara, Eliana. "Inequality and Group Participation: Theory and Evidence from Rural Tanzania.” Journal of Public Economics 85, no. 2 (2002): 235-273.

Labonne, Julien, and Robert S. Chase. "Who Is at the Wheel When Communities Drive Development? Evidence from the Philippines.” World Development 37, no. 1 (2009): 219-231.

Lanjouw, Peter, and Martin Ravallion. Benefit Incidence and the Timing of Program Capture. Policy Research Working Paper Series. The World Bank, 1998.

Leff, Nathaniel H. “Economic Development Through Bureaucratic Corruption.” American Behavioral Scientist 8, no. 3 (1964): 8-14.

Leys, Colin. "What is the Problem about Corruption.” Journal of Modern African Studies 3 (1965): 215-230.

Levitt, Steven D. "How Do Senators Vote? Disentangling the Role of Voter Preferences, 
Party Affiliation, and Senate Ideology.” American Economic Review 86, no. 3 (1996): 425-41.

Lien, Da-Hsiang Donald. “A Note on Competitive Bribery Games.” Economics Letters 22, no. 4 (1986): 337-41.

—. "Corruption and Allocation Efficiency." Journal of Development Economics 33, no. 1 (July 1990): 153-64.

Lui, Francis T. “An Equilibrium Queuing Model of Bribery.” Journal of Political Economy 93, no. 4 (1985): 760-81.

Mansuri, Ghazala, and Vijayendra Rao. "Community-Based and -Driven Development: A Critical Review.” The World Bank Research Observer 19, no. 1 (March 1, 2004): 139.

Mansuri, Ghazala, Vijayendra Rao, and World Bank. Localizing Development: Does Participation Work? Washington, D.C.: World Bank, 2013.

Mauro, Paolo. “Corruption and Growth.” The Quarterly Journal of Economics 110, no. 3 (1995): 681-712.

Mel, Suresh de, David McKenzie, and Christopher Woodruff. "Are Women More Credit Constrained? Experimental Evidence on Gender and Microenterprise Returns." American Economic Journal: Applied Economics 1, no. 3 (2009): 1-32.

Méon, Pierre-Guillaume, and Khalid Sekkat. "Does Corruption Grease or Sand the Wheels of Growth?” Public Choice 122, no. 1 (2005): 69-97.

Méon, Pierre-Guillaume, and Laurent Weill. "Is Corruption an Efficient Grease?” World Development 38, no. 3 (2010): 244-59.

Meux, E.P. "Concern for the common good in an N-person game.” Journal of Personality and Social Psychology 28 (1973): 414-8

Mills, C. Wright. The Power Elite. Oxford University Press, USA, 2000.

Mosse, David. "The Symbolic Making of a Common Property Resource: History, Ecology and Locality in a Tank-irrigated Landscape in South India." Development and Change 28, no. 3 (1997): 467-504. 
Myrdal, Gunnar. Asian Drama: An Inquiry Into the Poverty of Nations.(Vol.2). Pantheon, NY, 1968.

Narayan, Deepa, ed. Empowerment and Poverty Reduction: A Sourcebook. World Bank Publications, 2002.

Newman, John, Menno Pradhan, Laura B. Rawlings, Geert Ridder, Ramiro Coa, and Jose Luis Evia. "An Impact Evaluation of Education, Health, and Water Supply Investments by the Bolivian Social Investment Fund." World Bank Economic Review 16, no. 2 (2002): 241-274.

Olken, Benjamin A., and Patrick Barron. "The Simple Economics of Extortion: Evidence from Trucking in Aceh.” Journal of Political Economy 117, no. 3 (June 1, 2009): 41752.

Olson, Mancur, Jr. The Logic of Collective Action: Public Goods and the Theory of Groups. Harvard University Press, 1965.

Ortmann, Andreas, and Lisa K. Tichy. "Gender Differences in the Laboratory: Evidence from Prisoner’s Dilemma Games.” Journal of Economic Behavior \& Organization 39, no. 3 (1999): 327-39.

Osborne, Martin J., and Al Slivinski. "A Model of Political Competition with CitizenCandidates.” The Quarterly Journal of Economics 111, no. 1 (1996): 65-96.

Pan, Lei, and Luc Christiaensen. "Who Is Vouching for the Input Voucher? Decentralized Targeting and Elite Capture in Tanzania.” World Development 40, no. 8 (2012): 1619_ 1633.

Papke, Leslie E., and Jeffrey M. Wooldridge. "Econometric Methods for Fractional Response Variables with an Application to 401(K) Plan Participation Rates.” Journal of Applied Econometrics 11, no. 6 (1996): 619-32.

Patunru, A. R., and S.B. Wardhani. "Political Economy of Local Investment Climates: A Review of the Indonesian Literature." PAPI background paper for the Political Economy of the Local Investment Climate in Indonesia Project, Institute of Development Studies, Brighton, U.K. 2008

Perdana, Ari A., and John Maxwell. Poverty Targeting in Indonesia: Programs, Problems and Lessons Learned. CSIS Economics Working Paper Series. Centre for Strategic and International Studies, Jakarta, Indonesia, 2004.

Platteau, Jean-Philippe. “Community-based Development within the Context of within Group 
Heterogeneity.” Paper prepared for the Annual Bank Conference on Development Economics (2003).

Platteau, Jean-Philippe. "Monitoring Elite Capture in Community-Driven Development." Development and Change 35, no. 2 (2004): 223-246.

Platteau, Jean-Philippe, and Erika Seki. "Heterogeneity, Social Esteem and Feasibility of Collective Action.” Journal of Development Economics 83, no. 2 (2007): 302-325.

Pradhan, Menno, and Laura B. Rawlings. "The Impact and Targeting of Social Infrastructure Investments: Lessons from the Nicaraguan Social Fund.” World Bank Economic Review 16, no. 2 (2002): 275-295.

Pradhan, Menno, Vijayendra Rao and Christina Rosemberg. "The Impact of Community Level Activities of the Second Urban Poverty Project (UPP)". Department of Economics, University of Amsterdam, Amsterdam (2010).

Rao, Vijayendra. Symbolic Public Goods and the Coordination of Collective Actioom Comparison of Local Development in India and Indonesia. Policy Research Working Paper Series. The World Bank, 2005.

Rao, Vijayendra, and Ana Maria Ibanez. The Social Impact of Social Funds in Jamaica - a Mixed-methods Analysis of Participation, Targeting, and Collective Action in Community-driven Development. Policy Research Working Paper Series. The World Bank, 2003.

Rao, Vijayendra, and Michael Walton. Culture and Public Action. 1st ed. Stanford Social Sciences, 2004.

Ravallion, Martin. “Are Poorer States Worse at Targeting Their Poor?” Economics Letters 65, no. 3 (1999): 373-377.

Rehavi, M. “ Sex and Politics: Do Female Legislators Affect State Spending?” Working Paper, University of Michigan (2007).

Rose-Ackerman, Susan. International Handbook on the Economics of Corruption. Edward Elgar Publishing, 2006.

Rosen, Bernard C. "Review of Human Groups and Social Categories: Studies in Social Psychology. by Henri Tajfel.” American Journal of Sociology 90, no. 1 (July 1, 1984): 209-11. 
Sathe, Dhanmanjiri, Stephan Klasen, Jan Priebe, and Mithila Biniwale. "Can the Female Sarpanch Deliver?” Economic and Political Weekly 48, no. 11 (March 7, 2013): 50-57

Seabright, Paul. "Accountability and Decentralisation in Government: An Incomplete Contracts Model.” European Economic Review 40, no. 1 (1996): 61-89.

SEADI. "Evolution of Inequality in Indonesia, 1990-2013." SEADI Discussion Paper Series no.17. (2013).

Shleifer, Andrei, and Robert W. Vishny. “Corruption.” The Quarterly Journal of Economics 108, no. 3 (August 1, 1993): 599-617.

Smith, J, K Obidzinski, Subarudi, and I Suramenggala. "Illegal Logging, Collusive Corruption and Fragmented Governments in Kalimantan, Indonesia” 5, no. 3 (2003).

Spencer, Steven J., Claude M. Steele, and Diane M. Quinn. “Stereotype Threat and Women's Math Performance.” Journal of Experimental Social Psychology 35 (1999): 4-28.

Svaleryd, Helena. “Women's Representation and Public Spending.” European Journal of Political Economy 25, no. 2 (2009): 186-198.

Svensson, Jakob. "Who Must Pay Bribes and How Much? Evidence From A Cross Section Of Firms.” The Quarterly Journal of Economics 118, no. 1 (2003): 207-30.

Tajfel, Henri. Human Groups and Social Categories: Studies in Social Psychology. CUP Archive, 1981.

Tanzi, Vito and Davoodi, Hamid R. "Corruption, Public Investment, and Growth, in: George T. Abed and Sanjeev Gupta (Ed.)”. Governance, Corruption, \& Economic Performance, International Monetary Fund, Publication Services, Washington, D.C. (2002): 280-299.

Vedeld, Trond. "Village Politics: Heterogeneity, Leadership and Collective Action." The Journal of Development Studies 36, no. 5 (2000): 105-134.

Verdier, Thierry, and Daron Acemoglu. "The Choice between Market Failures and Corruption.” American Economic Review 90, no. 1 (2000): 194-211.

Vigdor, Jacob L. "Community Composition and Collective Action: Analyzing Initial Mail Response to the 2000 Census.” The Review of Economics and Statistics 86, no. 1 (2004): 303-12.

Waller, Christopher J., Thierry Verdier, and Roy Gardner. “Corruption: Top down or Bottom 
Up?” Economic Inquiry 40, no. 4 (2002): 688-703.

Wooldridge, J. Econometric Analysis of Cross Section and Panel Data. MIT Press. 2002.

World Bank. “World Development Report 2012: Gender Equality and Development.” World Bank, 2012.

World Bank. “Indonesia’s Decentralization after Crisis.” PREM World Bank, 2000.

World Bank. World Development Indicators 2005. World Bank Publications, 2005. 